\title{
Application of the BIOLOG microplate system to monitor the physiological response of heat-stressed bacteria
}

\author{
Matthew G. McCarroll \\ West Virginia University
}

Follow this and additional works at: https://researchrepository.wvu.edu/etd

\section{Recommended Citation}

McCarroll, Matthew G., "Application of the BIOLOG microplate system to monitor the physiological response of heat-stressed bacteria" (2008). Graduate Theses, Dissertations, and Problem Reports. 2657. https://researchrepository.wvu.edu/etd/2657

This Thesis is protected by copyright and/or related rights. It has been brought to you by the The Research Repository @ WVU with permission from the rights-holder(s). You are free to use this Thesis in any way that is permitted by the copyright and related rights legislation that applies to your use. For other uses you must obtain permission from the rights-holder(s) directly, unless additional rights are indicated by a Creative Commons license in the record and/ or on the work itself. This Thesis has been accepted for inclusion in WVU Graduate Theses, Dissertations, and Problem Reports collection by an authorized administrator of The Research Repository @ WVU. For more information, please contact researchrepository@mail.wvu.edu. 


\title{
Application of the BIOLOG microplate system to monitor the physiological response of heat-stressed bacteria
}

\author{
Matthew G. McCarroll \\ Sciences at West Virginia University \\ in partial fulfillment of the requirements for \\ the degree of \\ Master of Science \\ in \\ Environmental Microbiology \\ Gary Bissonnette, Ph.D., Chair \\ Alan Sexstone, Ph.D. \\ Jacek Jaczynski, Ph.D. \\ Department of Plant and Soil Sciences \\ Morgantown, West Virginia \\ 2008
}

Thesis submitted to the Davis College of Agriculture, Forestry and Consumer

Keywords: BIOLOG, Enterobacter sakazakii, substrate utilization, bacteria 


\section{ABSTRACT \\ Application of the BIOLOG microplate system to monitor the physiological response of heat-stressed bacteria}

\section{Matthew G. McCarroll}

The BIOLOG microplate system was originally evaluated by Miller and Rhoden (1991) for its ability to correctly identify clinical and environmental isolates. The system determines identity based on the exchange of electrons produced during utilization of a carbon substrate and subsequent respiration, leading to the reduction of a tetrazolium-based color change. Enteric bacteria (Escherichia coli, Enterobacter sakazakii, and Salmonella enterica serovar Typhimurium) were exposed to heat stress $\left(52^{\circ} \mathrm{C}\right)$ and samples were removed as a function of time $(0,15,30$ and $90 \mathrm{~min})$. Stressed cells were monitored with traditional viable cell counts and inoculated into BIOLOG GN plates. The stress response of enteric bacteria results in both physical changes, as reflected by their D-values and sublethal injury, and metabolic changes, as reflected by differential utilization of carbon substrates. Results indicate that the BIOLOG system may be used as a tool to monitor the physiological change of heat-stressed enteric bacteria. The BIOLOG system allows for three types of analysis of the metabolic changes taking place in heat-stressed enteric bacteria. The first two applications of the BIOLOG system demonstrated a generalized approach using AWCD and guild groupings as a tool to monitor physiological changes of heat-stressed enteric bacteria. The use of AWCD and guild groupings proved to be relatively ineffective in monitoring physiological changes in heat-stressed enteric bacteria. The third application that may be used demonstrate possible specific substrate utilization differences in heat-stressed enteric bacteria. Notable changes in specific substrate utilization were observed in thermally-stressed enteric bacteria with the use of the BIOLOG system. 


\section{Acknowledgements}

My appreciation is extended to my graduate committee for their cooperation and assistance. I am especially grateful for the guidance and patience of my advisor, Dr. Gary Kent Bissonnette, without his help this project would never have been able to be completed. In addition I would like to thank Dr. Alan J. Sexstone for allowing me to use his SpectraMax spectrophotometer to read my BIOLOG microplates, and Dr. Jacek Jaczynski for helping me with my D-value calculations.

I greatly appreciate all of the help from Alex Kish, Emily Kenney, Nicole Marshall, and all other faculty and graduate students in the Plant and Soil Science Department. They were always there to add their input and time to help this project succeed.

I would also like to thank my Mom and Dad for their loving support throughout my graduate career. They were always there when I needed them most, and helped me to be where I am today.

Finally, this project was partially supported through the Hatch fund (452). 


\section{Table of Contents}

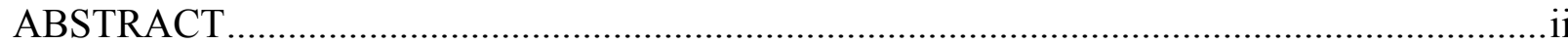

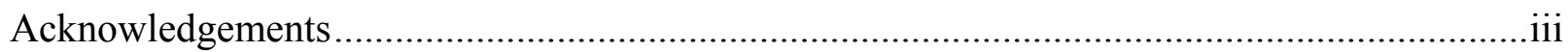

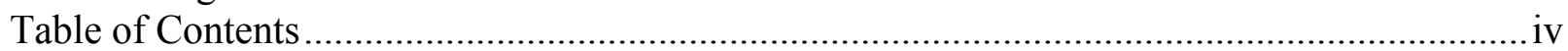

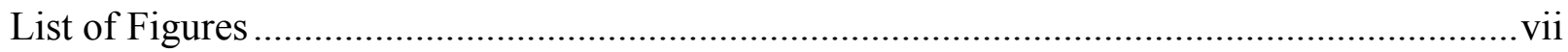

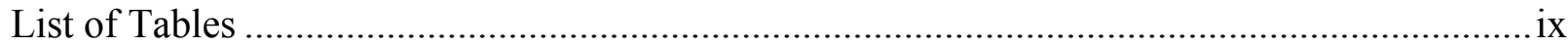

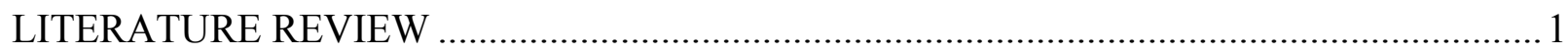

1. Bacterial Stress Response ........................................................................................ 1

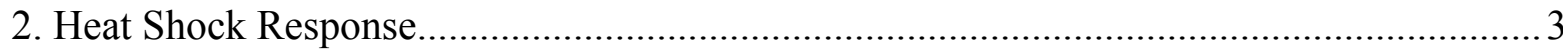

3. Osmotic Stress vs. Desiccation ..............................................................................

4. Antecedent Growth Conditions …........................................................................... 8

5. Methods Used to Identify Physiological Change ....................................................... 10

6. BIOLOG Microplate System ................................................................................... 11

7.0 Enterobacter sakazakii as an Emerging Food-borne Pathogen....................................... 13

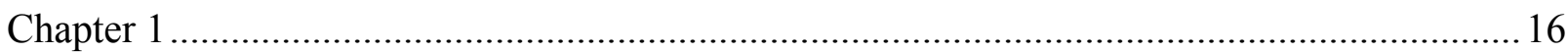

Evaluation of the BIOLOG microplate system as an alternative method for characterizing thermal stress of Escherichia coli, Enterobacer sakazakii, and Salmonella typhimurium ......... 16

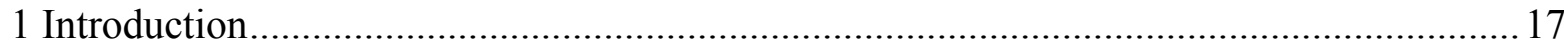

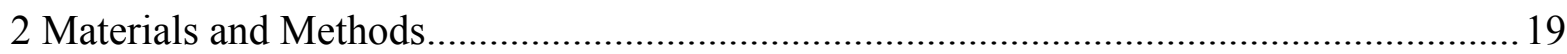

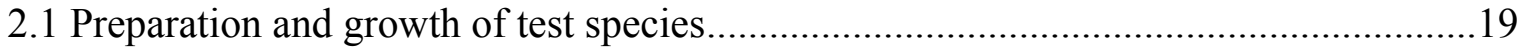

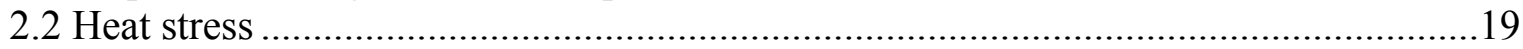

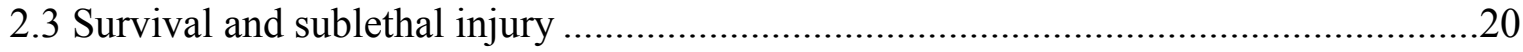

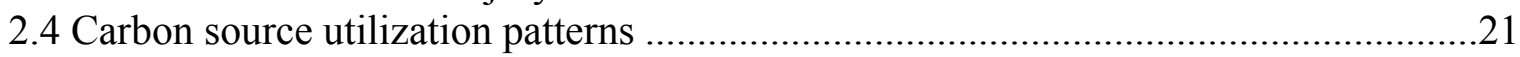

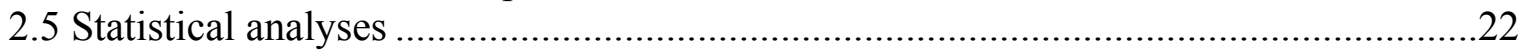

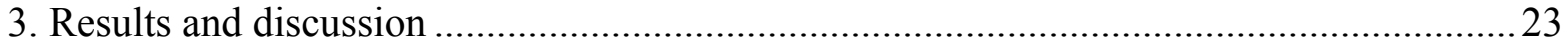

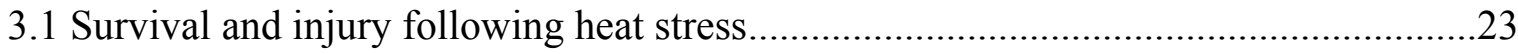

3.2 Differences in substrate utilization of control cells compared to heat stressed cells as determined by the BIOLOG plate system with the use of AWCD and guild

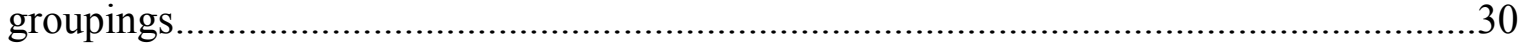

3.3 Differences in specific substrate utilization of heat-stressed cells as determined

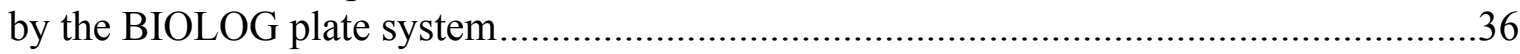

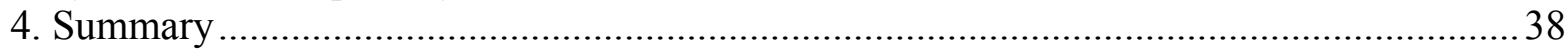




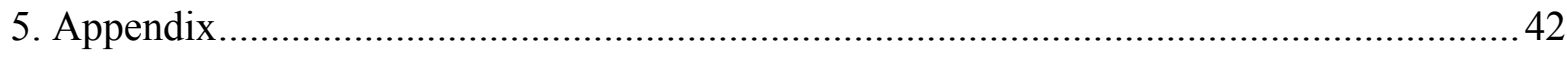

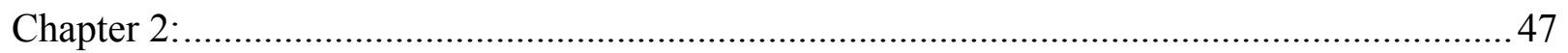

Evaluation of the physiological response of thermally-stressed Enterobacter sakazakii with the BIOLOG microplate system as influenced by antecedent growth conditions ...............47

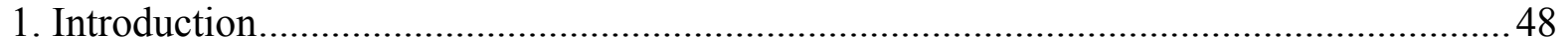

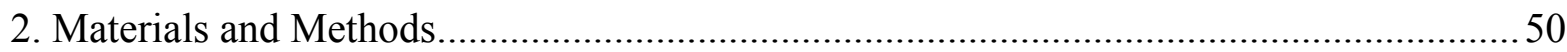

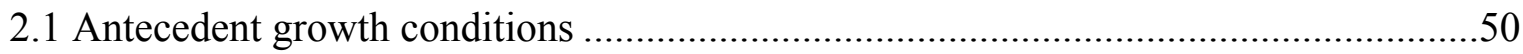

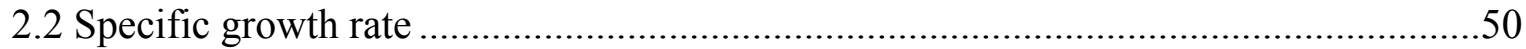

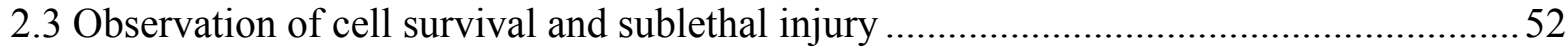

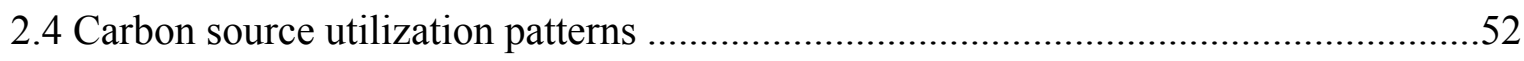

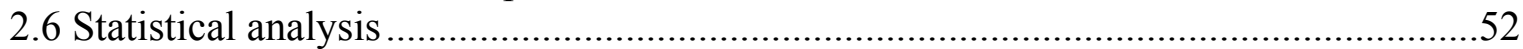

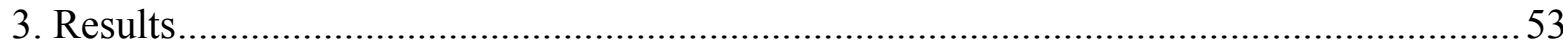

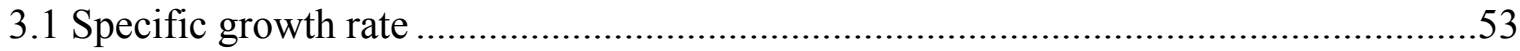

3.2 Survival and sublethal injury of heat-stressed cells ....................................................53

3.3 Effect of antecedent growth conditions on substrate utilization of heat-stressed cells as determined by the BIOLOG plate system with the use of AWCD and guild groupings............................................................................................................5

3.4 Effect of antecedent growth conditions on specific substrate utilization of heatstressed cells as determined by the BIOLOG plate system ..............................................59

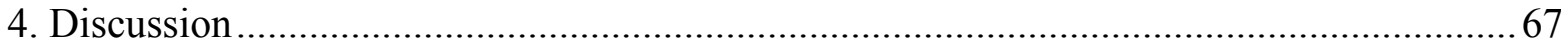

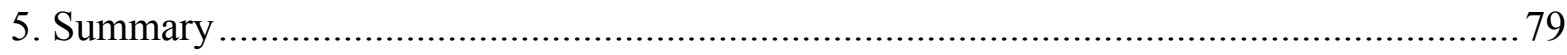

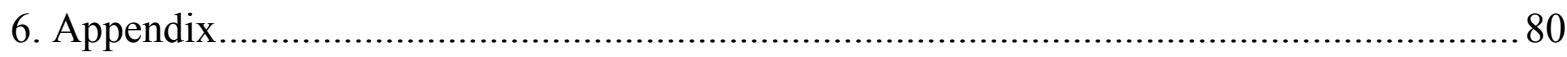

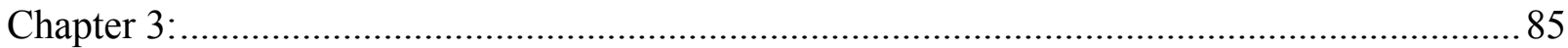

Application of the BIOLOG microplate system to assay physiological changes in

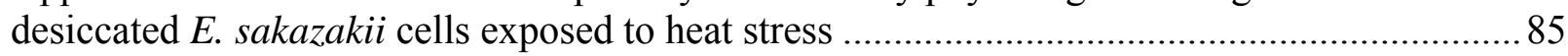

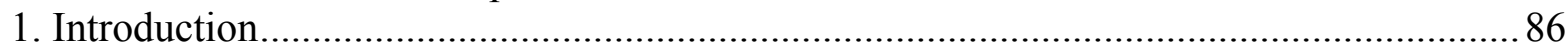

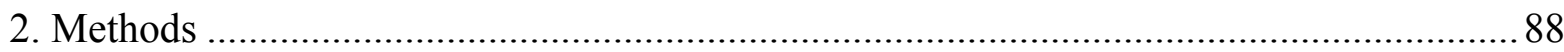

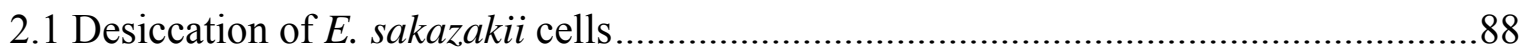

2.2 Survival and water activity determination of desiccated cells .....................................89

2.4 Carbon source utilization patterns ........................................................................... 89

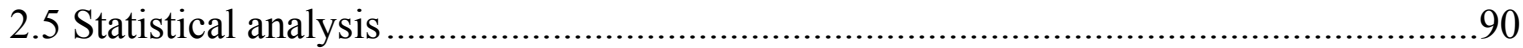

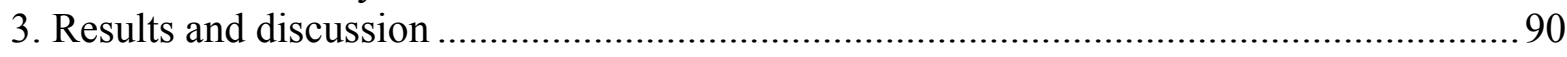

3.1 Exposure to heat stress and survival curves............................................................90

3.2 Effect of desiccation on substrate utilization of heat-stressed cells as determined by the BIOLOG plate system with the use of AWCD and guild groupings.......................90 
3.3 Effect of desiccation on specific substrate utilization of heat-stressed cells as determined by the BIOLOG plate system.........................................................................92

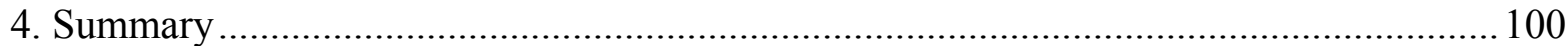

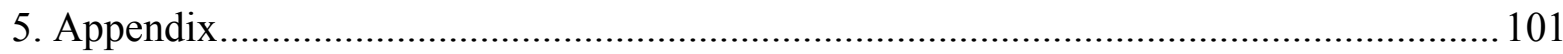

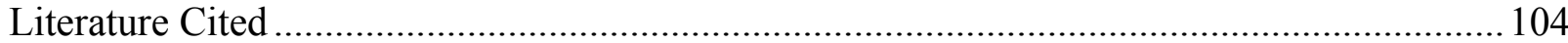

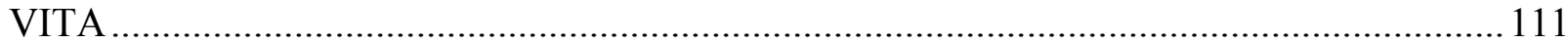




\section{List of Figures}

\section{Chapter 1}

Fig. 1.1. D-value determination of thermally-stressed enteric bacteria................................24

FIG 1.2. Survival curve of $E$. coli exposure to $52^{\circ} \mathrm{C}$ for $90 \mathrm{~min}$............................................25

FIG 1.3. Survival curve of E. sakazakii exposure to $52^{\circ} \mathrm{C}$ for $90 \mathrm{~min}$. ...................................26

FIG 1.4. Survival curve of S. typhimurium after exposure to $52^{\circ} \mathrm{C}$ for $90 \mathrm{~min}$......................27

FIG. 1.5. E. coli average AREA substrate utilization of guilds.........................................33

FIG. 1.6. E. sakazakii average AREA substrate utilization of guilds................................... 34

FIG. 1.7. S. typhimurium average AREA substrate utilization of guilds.............................. 35

FIG 1.8. Substrate utilization differences for E. coli after $90 \mathrm{~min}$ of heat stress.................... 43

FIG 1.9. Substrate utilization differences for S. typhimurium after $90 \mathrm{~min}$ of heat stress........ 44

FIG 1.10. Substrate utilization differences for S. typhimurium after $15 \mathrm{~min}$ of heat stress...... 45

FIG. 1.11 Substrate utilization differences for E. sakazakii after $90 \mathrm{~min}$ of heat stress............46

FIG 2.1. D-value determinations of thermally-stressed $\left(52^{\circ} \mathrm{C}\right)$ E. sakazakii cells

influenced by three antecedent growth conditions...........................................................5

FIG 2.2. Recovery of thermally-stressed $\left(52^{\circ} \mathrm{C}\right)$ E. sakazakii on non-selective (TSA, $\left.\bullet\right)$

and selective (MacConkey, $\mathbf{0})$ media as influenced by three different antecedent growth conditions

FIG. 2.3. Substrate utilization of BIOLOG guilds (expressed as average AREA) for heat

stressed $\left(52^{\circ} \mathrm{C}\right)$ E. sakazakii previously grown in full strength TSB at $25^{\circ} \mathrm{C}$.......................6 60

FIG. 2.4. Comparison of substrate utilization of BIOLOG guilds (expressed as average

AREA) for 90 min heat-stressed $\left(52^{\circ} \mathrm{C}\right) \mathrm{E}$. sakazakii previously grown in full strength

TSB at $35^{\circ} \mathrm{C}$ and at $25^{\circ} \mathrm{C}$.

FIG. 2.5. Substrate utilization of BIOLOG guilds (expressed as average AREA) for heat

stressed $\left(52^{\circ} \mathrm{C}\right) \mathrm{E}$. sakazakii previously grown in $1 / 10$ strength $\mathrm{TSB}$ at $35^{\circ} \mathrm{C}$.

FIG. 2.6. Comparison of substrate utilization of BIOLOG guilds (expressed as average AREA) for 90 min heat-stressed $\left(52^{\circ} \mathrm{C}\right) \mathrm{E}$. sakazakii previously grown in full strength

TSB and $1 / 10$ strength TSB at $35^{\circ} \mathrm{C}$.

FIG 2.7. Pentose-phosphate metabolism in enteric bacteria............................................... 78

FIG 2.8. Differences in substrate utilization of 90 min heat-stressed E. sakazakii

previously grown at $25^{\circ} \mathrm{C}$ in TSB compared to substrate utilization of non-heated control cells previously grown at (A) $25^{\circ} \mathrm{C}$ and (B) $35^{\circ} \mathrm{C}$.

FIG. 2.9. Differences in substrate utilization of 90 min heat-stressed E. sakazakii

previously grown in 1/10 strength TSB compared to substrate utilization of non-heated

control cells grown in (A) $1 / 10$ strength TSB at $35^{\circ} \mathrm{C}$ and (B) full strength TSB at $35^{\circ} \mathrm{C}$....... 82

FIG. 2.10. Differences in substrate utilization of 90 -min heat stressed $\left(52^{\circ} \mathrm{C}\right)$ E. sakazakii

previously grown in full strength TSB at $25^{\circ} \mathrm{C}$ compared to substrate utilization of 90

min heat-stressed cells previously grown in full strength TSB at $35^{\circ} \mathrm{C}$.

FIG. 2.11. Differences in substrate utilization of 90 -min heat stressed $\left(52^{\circ} \mathrm{C}\right) \mathrm{E}$.

sakazakii previously grown in $1 / 10$ strength $\mathrm{TSB}$ at $35^{\circ} \mathrm{C}$ compared to substrate

utilization of 90 min heat-stressed cells previously grown in full strength TSB at $35^{\circ} \mathrm{C}$

FIG. 3.1. D-value determinations of thermally-stressed $\left(52^{\circ} \mathrm{C}\right)$ E. sakazakii as influenced

by desiccation. 
FIG. 3.2. Substrate utilization of BIOLOG guilds (expressed as average AREA) for heat stressed $\left(52^{\circ} \mathrm{C}\right.$ for $\left.90 \mathrm{~min}\right)$ E. sakazakii previously desiccated.

FIG. 3.3. Substrate utilization of BIOLOG guilds (expressed as average AREA) for 90 min heat-stressed $\left(52^{\circ} \mathrm{C}\right.$ for $\left.90 \mathrm{~min}\right)$ E. sakazakii previously desiccated and not desiccated.

FIG. 3.4. Differences in substrate utilization of desiccated E. sakazakii cells exposed to 90 min of heat stress compared to substrate utilization of non-heated control cells previously A) desiccated, B) not desiccated, and C) 90 min heat stressed cells not previously desiccated

FIG. 3.5. Differences in substrate utilization of non-heated control E. sakazakii cells previously desiccated compared to substrate utilization non-heated control cells not previously desiccated. 


\section{List of Tables}

\section{Chapter 1}

TABLE 1.1. Decimal reduction times (min) for three test organisms following heat stress for $90 \mathrm{~min}$

TABLE 1.2. Average well color development (AWCD) of the three test organisms during heat stress.

TABLE 1.3. Utilization of specific BIOLOG substrates by heat-stressed $\left(52^{\circ} \mathrm{C}\right.$ for 90 $\min$ ) bacteria species compared to substrate utilization of non-heated control cells. 39

TABLE 1.4. Utilization of specific BIOLOG substrates by heat-stressed Salmonella typhimurium compared to substrate utilization of non-heated control cells

TABLE 2.1. Enterobacter sakazakii growth conditions and specific growth rate.

TABLE 2.2. Average well color development (AWCD) of E. sakazakii following heat stress $\left(52^{\circ} \mathrm{C}\right)$ as influenced by different growth conditions.

TABLE 2.3. Utilization of specific BIOLOG substrates by heat-stressed $\left(52^{\circ} \mathrm{C}\right.$ for 90 min) Enterobacter sakazakii cultured under different antecedent growth conditions compared to substrate utilization by non-heated control cells

TABLE 2.4. Utilization of specific BIOLOG substrates by heat-stressed $\left(52^{\circ} \mathrm{C}\right.$ for 90 min) E. sakazakii cultured under non-optimum conditions $\left(1 / 10 \mathrm{TSB}\right.$ at $35^{\circ} \mathrm{C}$ and TSB at $25^{\circ} \mathrm{C}$ ) compared to substrate utilization by heat-stressed cells cultured under optimum conditions (TSB at $\left.35^{\circ} \mathrm{C}\right)$

TABLE 2.5. Average specific growth rate, D-value, and sublethal injury of E. sakazakii as influenced by different growth conditions.

TABLE 3.1. Average well color development (AWCD) of E. sakazakii following heat stress $\left(52^{\circ} \mathrm{C}\right)$ as influenced by desiccation.

TABLE 3.2. Utilization of specific BIOLOG substrates by desiccated heat-stressed $\left(52^{\circ} \mathrm{C}\right.$ for $90 \mathrm{~min}$ ) Enterobacter sakazakii compared to substrate utilization by non-heated control cells.

TABLE 3.3. Utilization of specific BIOLOG substrates by desiccated Enterobacter sakazakii exposed to heat or no heat compared to substrate utilization by non-desiccated cells. 


\section{LITERATURE REVIEW}

\section{Bacterial Stress Response}

Most Enterobacteriaceae bacteria spend a portion of their life cycle in an animal host, where there is a constant supply of nutrients and stable environment. Once excreted from the host, bacteria become exposed to an unstable environment with associated stresses, facing limited nutrient availability, osmotic stress, and variations in temperature and $\mathrm{pH}$, possibly resulting in a loss in viability and inhibition of growth (88). In order to counteract this inhibition, microorganisms use a multitude of sensing and effector mechanisms to adapt to stressful environments. These conditions cause the bacterium to go into a response stage called the stringent response, which consists of an increase in gene expression of $\sigma^{\mathrm{S}}$ and $\sigma^{70}$. This tradeoff from resources needed for growth, to those needed to protect and repair vital cellular components shows the commitment towards survival that bacteria take when exposed to a nutrient-limiting environment (2).

The ability of bacteria to remain viable under stress conditions, such as nutrient depletion in the natural environment, is dependent on the bacterium entering the stationary phase of growth. Stationary phase has been characterized as a starvationinduced growth phase that results in a metabolically less active state (76). A number of morphological and physiological changes take place during stationary phase, as cells accumulate storage and protective compounds, become smaller and rounder, and the DNA condenses. There are also many changes in the membranes of the cells, including shrinkage of the cytoplasmic membrane, degradation and use of membrane phospholipids as a carbon source, and a number of changes in the composition of fatty acid and proteins 
in the inner and outer membranes (21). These changes, as well as changes in gene expression, result in an increased resistance towards an array of environmental stresses (heat, osmotic, $\mathrm{pH}$, or oxidative). Once in stationary phase, the expression of the regulatory gene rpoS is induced and is inversely correlated with growth rate. HenggeAronis et al. (30) stated that the rpoS gene is required for glycogen synthesis, thermotolerance, determination of cell shape and size, and long term starvation survival.

Recent findings that specific growth rate correlates with sensitivity towards specific stresses supports the hypothesis that stationary phase cells may be more resistant to environmental stress. Berney et al. (5) showed that a decrease in specific growth rate corresponded with a decrease in sensitivity towards stresses (mild heat and ultra-violet radiation). Furthermore, Ihssen and Egli (34) observed that the global stress regulatory protein RpoS is increasingly expressed with decreasing specific growth rate. In addition, it was shown that in response to heat stress, the heat shock protein (HSP) HtpG is overexpressed when grown in a complex medium while its expression remains unchanged when cells are grown on glucose, glycerol, or pyruvate (52). In a related study, E.coli grown in a carbon limited medium, with specific growth rate of $0.03-0.1 \mu$ $\left(\mathrm{h}^{-1}\right)$, showed a stronger induction of the general stress response than cells grown in a carbon rich medium, with a specific growth rate of $0.3-0.5 \mu\left(\mathrm{h}^{-1}\right)$. This observation supports the hypothesis that specific growth rate may decrease sensitivity towards stress (34). These data further imply that periods of slow growth may induce a stress response.

It has also been proposed that as a final means towards survival a bacterium can enter a viable but nonculturable (VBNC) state. The VBNC hypothesis describes an apparent dormant state driven by extreme conditions, in which cells are still metabolically active 
but cannot be cultured in the lab (88). According Roszack and Colwell (71), the VNBC state is analogous to spore formation in that cells remain viable but not metabolically active. Research has shown that protein expression patterns between stationary phase and VBNC cells were significantly different, suggesting a physiological change in cells to allow survival under extreme conditions (2). Identification of the physiological changes that take place may lead to better recovery methods of VBNC cells.

\section{Heat Shock Response}

Of all the stress responses, the heat shock response has been one of the most studied. High temperatures cause protein unfolding and denaturization, which may expose hydrophobic patches at the surface of the cell membrane, and can result in aggregation of proteins causing serious threat to the organization and functioning of all cytoplasmatic components in the cell. To counteract this effect, some bacteria produce heat shock proteins (HSP) that act as chaperones to assist in refolding the unwound proteins. In $E$. coli at $46^{\circ} \mathrm{C}$, HSP consist of $20-25 \%$ of the total protein expression, mostly chaperones and ATP-dependent proteases, and is regulated by the sigma factor $\sigma^{32}$. However, with this increased amount of protein translation the cell must also maintain a balance between the protective effect of the HSP and the metabolic burden of expressing them (17).

The heat shock response has been extensively studied, especially with regard to specific protein synthesis, metabolism, gene expression, and thermotolerance. Arsene et al. (3) described two classes of HSP of E. coli: molecular chaperones DnaK, DnaJ, GrpE, GroEL, and GroES; and proteases Lon, ClpAP, ClpXP, HslUV, and FtsH. Both are positively controlled at the transcriptional level by the heat shock promoter sigma-32 subunit of RNA polymerase, which is triggered not only by increased temperature but 
also by ethanol, certain antibiotics, hydrogen peroxide, amino acid restriction, and carbon starvation (86). Most of these chaperones and proteases are already operative under normal growth conditions due to additional promoters but become increasingly important with exposure to stress conditions. Apparently, the regulation of HSP is not only important under stress but under all growth conditions through control of the folding and degradation of proteins.

With an increased expression of proteins there comes a higher metabolic demand for specific carbon substrates. As mentioned previously, specific growth rate has a dramatic effect on a cells ability to survive and resist stressful conditions. It may then be suggested that the growth medium has an effect on a cell's ability to express differing levels of HSP when exposed to elevated temperatures. Herendeen et al. (31) grew batch cultures of bacteria on both LB medium and glucose-minimal medium. Results show that bacteria grown on LB had an increase in molecular chaperone expression, whereas cells growing on glucose-minimal media had no such increase. Similarly, Matthews and Neidhardt (53) observed elevated serine catabolism following the heat shock response in E. coli. The rate of serine catabolism increased sharply at temperatures above $37^{\circ} \mathrm{C}$ and seemed to parallel the induction of the heat shock response. These observations showed that elevation in L- serine deaminase activity would increase cellular pools of pyruvate or acetyl coenzyme A, suggesting these pools may be involved in the induction of HSP (53).

In E. coli, a non-lethal temperature shift from $30^{\circ} \mathrm{C}$ to $42^{\circ} \mathrm{C}$ causes induction of HSP. Surviving cells subsequently exposed to more lethal temperatures demonstrate an increased survival rate. Such a thermotoelrance response develops as a result of a faster heat shock response and induction of HSP which mediates an efficient recovery from the 
stress-induced damage (15). The degree of acquired thermotolerance is of particular importance to the food industry. It has been proposed that both physiological changes and genetic changes are responsible for this increase in heat resistance. As mentioned previously, increased levels of stress damage proteins are important to the structure and function of the outer membrane, with particular importance related to the release of lipopolysaccharide (LPS), a specific component of the outer membrane. After exposure to sublethal temperatures, E.coli synthesizes LPS, thus helping to repair the damaged outer membrane. In addition, increased levels of HSP and outer membrane protein synthesis occurred during the repair process (83). Along with a rise in HSP synthesis, genetic data revealed roles for components for the heat shock regulon in acquisition of thermotolerance (81). Therefore, a cell that already has an increased level of HSP synthesis can be exposed to higher temperatures with an increased chance of survival.

Finally, the structure of DNA may also aid in sensitivity towards heat stress. Under normal growth conditions for E. coli, supercoiling of the DNA increases with increasing growth temperature, but once the heat shock regulon becomes induced a rapid relaxation of the DNA occurs. This relaxation of the DNA has also been seen in thermophilic Archaea plasmid DNA, therefore suggesting that modulation of local DNA may be important in the heat shock response (81).

\section{Osmotic Stress vs. Desiccation}

In general, cell membranes are semi-permeable, thus allowing water and other small molecules to freely pass but are impermeable to larger molecules and certain solutes. Therefore, an increased concentration of a solute (osmolarity) will cause water to leave the cell; whereas, a decrease in osmolarity will cause water to enter the cell. Both cases 
have the potential to cause stress by affecting the bacterial cell membrane, cytoplasm, and periplasm. Cells exposed to a hyperosmotic environment react by increasing the concentration of macromolecules to the point where they can make up $\sim 50 \%$ of a cell's volume. At such high concentrations, cytoplasmic crowding has been suggested to shape the cells volume into networks of electrolyte pathways and pools, causing a flow of biochemical ions through the cytoplasm (77). These electrostatic effects may have a significant impact on protein mobility in the cytoplasm, causing osmotic stress.

Response to osmotic stress is multifaceted with a specific sequence of cellular events. In order for growth to occur at low osmolarity, a cell must reduce its cytoplasmic potassium, an osmotic contributor, helping to avoid developing too large a turgor pressure (65). Generally, cells are more likely to become exposed to high osmotic conditions resulting in an efflux of water, which may cause an increase in intracellular metabolite and ion concentration. To avoid this condition, cells actively transport potassium into the cell and begin glutamate synthesis. The potassium glutamate is later replaced with osmoprotectants, which are more compatible with cell growth (66). It has also been suggested by Higgins et al. (33) that an increase in osmolarity results in increases in DNA supercoiling which may induce transcription of osmotic stress genes.

As described previously, compatible solutes replace other ions to aid with cell growth during high osmotic growth conditions, and can be accumulated through synthesis or transport from the environment. These organic osmolytes can be accumulated by the cell to exceedingly high concentrations without disrupting vital cellular functions or the folding of proteins (75). This increased accumulation counteracts the effects of the osmotic efflux of water through the membrane allowing restoration of turgor and 
recommencing growth under low water activity conditions (89). When exposed to high osmotic conditions most gram-negative bacteria elicit an increased accumulation of glycine betaine through the use of high affinity transport systems (75). Utilization of glycine betaine is controlled by the multicomponent transport system ProU, which is induced by an increase in DNA supercoiling (33) and $\mathrm{Na}^{+}$concentrations (89). The other major osmoprotectant is glutamate which begins to accumulate within one minute of exposure to osmotic conditions in E. coli (89).

Loss of water activity can be very stressful and result in death to many cells, yet some bacterial cells are able to survive extreme desiccation. Consequences of drying are essentially different from those resulting from osmotic stress, as cells must rely on previous accumulation of specific molecules to serve some structural or protective role before becoming metabolically inactive (66). The intracellular accumulation of a nonreducing saccharide, such as trehalose and sucrose, helps to increase survival of dessicated cells by protecting liposomes and biological membranes (8). During the desiccation process, water is being removed from the lipid bilayers and headgroups are brought closer together. This causes the dry bilayer to form into a gel phase at room temperature where it has been proposed to potentially lead to membrane leakage and cell death. The addition of a disaccharide before dessication helps to increase survival by replacing the water between the lipid headgroups, thus preventing membrane leakage after rehydration (46). Subsequently, the addition of the osmoprotectants, trehalose and sucrose, aid in survival of bacteria exposed to desiccation. Accordingly, bacteria exposed to dessicating conditions may have a shift in metabolism to help synthesize these 
disaccharides. Synthesis of either disaccharide is practical as it requires only two gene products, a synthase (reaction 1) and a phosphatase (reaction 2) (46).

Reaction 1

$$
\text { UDP-Glc + Fru-6-P } \rightarrow \text { Suc-6-P + UDP or UDP-Glc + Glc-6-P } \rightarrow \text { Tre-6-P + UDP }
$$

Reaction 2

$$
\begin{aligned}
& \text { Suc-6-P } \rightarrow \text { Suc }+ \text { P and Tre-6-P } \rightarrow \text { Tre }+\mathrm{P} \\
& \text { Fru-6-P = fructose-6-phosphate, Suc-6-P = sucrose-6-phosphate, Tre-6-P = trehalose-6- } \\
& \text { phosphate, Glc-6-P = glucose-6-phosphate and UDP = uridinediphosphate }
\end{aligned}
$$

These reactions suggest that an increase in Fru-6-P and Glc-6-P may be seen in a cell exposed to extreme osmotic conditions before desiccation occurs and the cell becomes metabolically inactive.

\section{Antecedent Growth Conditions}

Studies designed to examine the physiological response of a bacterium to heat shock usually involve the growth of the bacteria under controlled experimental conditions in nutrient rich media and at optimum growth temperature. However, the artificial growth conditions do not accurately reflect the environment in which the cells naturally preside, as fluctuations in temperature and nutrients are likely to occur. It has been well documented that antecedent growth conditions can alter the response of an organism to disinfection agents $(5,78,80)$; thus, it would seem plausible that differences in growth conditions would have an effect on an organism's response to heat shock.

One particularly important antecedent growth condition is growth of the cell under a nutrient-limiting environment. Naturally occurring enteric bacteria spend most of their life in the nutrient rich environment of mammal guts. However, part of their life cycle may include the survival and/or growth in low-nutrient environments such as 
surface water. Such environments may contain minute traces of amino acids resulting in increased synthesis of enzymes needed for amino acid biosynthesis and precursor uptake. However some studies have shown an increase synthesis of enzymes can also be used for enhanced nutrient sensing (51). This energy taxing increase in amino acid synthesis may decrease the growth rate by inhibiting the global processes of DNA/RNA synthesis needed for cell replication.

The induction of starvation proteins may also result in resistance to other stresses. Jenkins et al. (38) showed that starved cells developed maximal thermotolerance after $4 \mathrm{~h}$ of growth, thus suggesting that proteins of the late temporal class of starvation proteins may play an important role in cross protection. Microbial cross protection systems may be multifactor with one or two factors improving resistance of stress to a third factor. Growth of E.coli $\mathrm{O} 157: \mathrm{H} 7$ at $10^{\circ} \mathrm{C}$ and under starvation conditions led to improved thermal tolerance at $52^{\circ} \mathrm{C}(92)$. The induction of increased heat resistance may be the result of survivors exhibiting starvation protein synthesis and a decreased growth rate due to absence of nutrients and entrance into stationary phase.

Increasing growth temperatures may stimulate the synthesis of thermostable membranes, thus increasing thermal resistance of the organism (44). Previous studies have also indicated that cells grown at lower temperatures become more resistant to disinfectants than cells grown at higher temperatures (78). In a study by Kandhai et al. (39) it was shown that temperature had a significant effect on the specific growth rate of Enterobacter sakazakii cells. Cells grown at $21^{\circ} \mathrm{C}$ showed a specific growth rate of $\sim 1.0$ $\mathrm{h}^{-1}$ compared to cells grown at $37^{\circ} \mathrm{C}$ which showed a $\sim 2.29 \mathrm{~h}^{-1}$ specific growth rate during the log phase. This increase in growth rate could have an effect on the cells ability 
to respond to stress. As previously stated, a decrease in specific growth rate corresponds with a decrease in sensitivity towards stresses (5). More research is needed to observe any possible correlation since colder temperatures are common in aquatic environments.

\section{Methods Used to Identify Physiological Change}

Various methodologies used to identify the physiological change in bacteria when exposed to environmental stress may aid in the identification of viable but non-culturable bacteria (VBNC). The classical approach of detecting these changes deal with total plate counts and selective plate counts for sublethal injury. Spread plating allows for the direct enumeration of culturable bacteria on a rich non-selective medium such as plate count agar (PCA) or trypticase soy agar (TSA). Injury has been described as sublethal physiological damage resulting from the exposure to an environmental stress that causes the organism to lose the ability to grow on a selective medium which is satisfactory for the growth of normal cells (10).

Failure of injured cells to grow on selective media may result in the underestimation of the total concentration of bacteria in food or water. In order to enhance detection of injured cells, efforts have been directed to improving recovery methods. Direct viable counts have been used in the enumeration of bacterial density and viability. Using a membrane and nucleic acid stain, direct viable counts allow for the distinction between live and dead cells. Continuous development of new stains and procedures has made flow cytometry an attractive method for examining physiological change and cell viability/cell death. These dyes are based on membrane permeability and membrane potential, allowing for the comparison of viable cells versus dead cells in a population that has been exposed to stress. However, even with the continuous development of new 
stains, no stain allows for a complete analysis of bacterial physiology. In addition, staining living cells that have slightly damaged membranes from increased exposure to stress has been found to be difficult (84). An added variable factor is that of investigator bias, as differences in estimates between observers are likely to occur depending on the interpretation of what constitutes a countable bacterial cell (40). Another important problem with the direct viable count method is the lack of agreement on standard procedures given that most studies do not indicate the magnification, preservation, dispersion techniques, filter types, and counting strategies (40). The inconsistencies of the direct viable count could lead to a lack of precision when enumerating physiologically injured bacterial cells.

\section{BIOLOG Microplate System}

The BIOLOG microplate system was introduced in the early 1990's and was

originally used to identify microorganisms based on their ability to oxidize a panel of 95 different carbon sources, ranging from organic acids to sugars (55). The assay is based on a redox reaction with the use of a tetrazolium indicator dye to show a color change in each well. BIOLOG was initially designed for the use of identifying human isolates and environmental contaminants in the clinical setting, but more recently it has been used to examine the microbial catabolic diversity of selected communities. The use of BIOLOG for expressing the functional diversity in soil communities was first described by Garland and Mills (26). Their method uses the same concept as originally described, with the use of a tetrazolium indicator dye in each well, and offers a community-level catabolic profile that can be compared with communities found in similar habitats. This method has successfully been used to identify the potential metabolic diversity of communities found 
in soils, plant rhizospheres, and contaminated sites. Roling et al. (70) used the BIOLOG system to study the anaerobic microbial community in aquifers. They were able to distinguish microbial communities from polluted aquifers below a landfill from those located up or downstream of the landfill (70). Engelen et al. (18) used BIOLOG and temperature gradient gel electrophoresis (TGGE) to monitor the impact of pesticides on bacterial soil communities. After 32 hours, differences from the control were seen in the Herbogil pesticide treatment, as a reduction in color development was predominant in three of the eight rows of wells in the BIOLOG microplate. These data suggested that pesticide application had an inhibiting effect on the catabolic potentials of the microbial community (18).

The large diversity of substrates included in BIOLOG microplates suggest this system could be utilized to determine the physiological change in a bacterium following stress. Ihssen and Egli (35) examined the catabolic flexibility of Escherichia coli cells growing on carbon-limited chemostat cultures. E.coli grown on glucose-limited and glucose batch cultures were incubated in BIOLOG GN microplates to compare their catabolic flexibility. E.coli grown in the glucose-limited chemostat culture was able to oxidize 43 substrates as compared to the glucose batch culture which was only able to oxidize seven substrates. The observed physiological adaptations suggest that BIOLOG microplates could potentially be used to evaluate stress induced metabolic responses, thereby producing a novel approach for assaying stress responses in bacteria. Results of this assay could prove to be beneficial in the identification of important substrates related to bacteria found in food and water. 


\subsection{Enterobacter sakazakii as an Emerging Food-borne Pathogen}

Enterobacter sakazakii, a gram-negative bacterium belonging to the family Enterobacteriaceae, was characterized by Farmer et al. (22). It is considered an emerging opportunistic pathogen and has been associated with meningitis, necrotizing enteritis, and bacteremia in low birth weight and immuno-compromised babies (6). Mortality rates as high as $50 \%$ have been observed and meningitis survivors often suffer severe neurological disorders. Multiple cases of E. sakazakii necrotizing enterocolitis and meningitis have been reported in neonatal intensive care units because of the persistence of this organism (37). In most cases powdered infant formulas have been implicated as the possible source of infection. Presumably contamination occurs after pasteurization, as it has not been shown that E. sakazakii has the capability of surviving these high temperatures (11). With this in mind, contamination of dried infant formula would most likely occur during the filling processes or improper storage of infant formula. Edelson-Mammel and Buchanan (16) showed that E. sakazakii has the capability of survival in powdered infant formula for at least 18 months. Dried infant formula has an $\mathrm{a}_{\mathrm{w}}$ of 0.2 , which will largely impact the survival of any bacterial population and suggests that survival depends on the osmotic and dry stress resistance of the bacterium. Breeuwer et al. (11) observed that E. sakazakii was much more resistant to air drying than other Enterobacteriaceae, with the suggestion that increased accumulations of trehalose aid in this increased survival.

E. sakazakii has been detected in infant formulas, ranging from $2.4 \%$ to $14.2 \%$ of samples testing positive $(36,47,58)$. E. sakazakii has been shown to be able to grow in temperatures ranging from $6^{\circ} \mathrm{C}$ to $47^{\circ} \mathrm{C}$, with the optimum growth temperature between 
$37^{\circ} \mathrm{C}$ and $43^{\circ} \mathrm{C}$ (37). However, Kandhai et al. (39) reported that cell history has no affect on E. sakazakii growth rate in infant formula at temperatures between $8-47^{\circ} \mathrm{C}$.

E. sakazakii has also been isolated from ground meat, surface water, soil, domestic animals, and thermal mineral water springs (36). The wide range of environments that E. sakazakii has been isolated from and the suggestion that contamination most probably occurs from the food processing environment indicates $E$. sakazakii may reside in the natural environment. Although studies have failed to identify an environmental source based on physiological features, Iversen et al. (37) suggested that plant material is a likely habitat. Mullane et al. (57) reported that yellow pigment production may protect E. sakazakii from UV radiation. Also, capsule and resulting biofilm formation in E. sakazakii may aid in adherence of cells to plant surfaces. The well known dessication resistance properties of E. sakazakii also aid in survival as plantassociated bacteria frequently encounter various environmental stressors, such as dessication. In a recent study (66) it was observed that E. sakazakii produces a yetundescribed protein which is homologous with Erwinia carotovrara, a known plant pathogen. In E. carotovora, this enzyme has been identified as a virulence factor that aids in the maceration of plant cells. The up regulation of this enzyme may be a yetunidentified virulence factor associated with E. sakazakii cells induced by desiccation (66).

Biofilm formation on biotic and abiotic surfaces may be another survival strategy employed by E. sakazakii. The presence of E. sakazakii on surfaces of utensils and equipment used to prepare and store infant formula has been observed in clinical settings (43). The creation of biofilms aids in the resistance to environmental stresses such as 
heat, osmotic pressure, UV light, acids, disinfectants and antibiotics by creating a physical barrier due to the secretion of an exopolysaccharide (44). Increased resistance to disinfectants by E. sakazakii that has adhered to equipment used in the production and preparation of infant formula raises the possibility that infections may occur. For this reason improved detection methods are needed in order to enhance recovery of environmentally stressed E. sakazakii. 


\section{Chapter 1}

Evaluation of the BIOLOG microplate system as an alternative method for characterizing thermal stress of Escherichia coli, Enterobacer sakazakii, and Salmonella typhimurium 


\section{Introduction}

Bacteria are constantly being exposed to a multitude of environmental stresses and the ability to remain viable under these conditions is dependent on a mixture of sensing and effector mechanisms (2). In addition to such mechanisms, physiological changes occur including size reduction, decrease in RNA content, reduction of metabolic activity, increased resistance to certain environmental stresses, and persistence in the environment (5). The classification and characterization of such changes may help to describe factors responsible for long term survival in stressful conditions, such as in drinking water and during food production/preservation. Most studies used to identify the physiological changes that take place during stress conditions have involved microscopic methods such as direct viable count (DVC) and flow cytometry. DVC is used most often in combination with a live/dead bacterial kit and fluorescent in situ hybridization (FISH), a phylogenetic stain, for identification and determining viability of a species (73). Flow cytometry is used to sort individual cells by defining specific criteria. These cells are then analyzed based on comparison between populations which are exposed to different phylogenetic stains (14). Although these methods require only a few cultivation steps, their use may be time consuming and lead to an overwhelming amount of data that are not needed when dealing with a pure culture.

The use of the BIOLOG identification system was originally evaluated by Miller and Rhoden (55) for its ability to correctly identify clinical and environmental isolates. The BIOLOG microtiter plate determines identity based on the exchange of electrons produced during utilization of a carbon substrate and subsequent respiration, leading to the reduction of a tetrazolium-based dye which changes color. The microtiter plate 
evaluates the ability of an organism to oxidize a panel of 95 different carbon sources, ranging from organic acids to sugars. In theory, different species should produce an individual pattern of positive purple wells which would make up a "metabolic fingerprint" (26). Knowledge of the metabolic fingerprints for different species permits identification of an unknown clinical or environmental isolate.

The BIOLOG system has been used in ecological studies to determine heterotrophic microbial community structure. Garland and Mills (26) first introduced this method based on community-level physiological profiles (CLPPs) by describing the relative utilization pattern of multiple substrates. The inoculation of microbial communities into BIOLOG plates leads to response patterns that distinguish populations from both different and similar soil habitats. Subsequently, numerous studies have used the BIOLOG system to examine community analysis but very few studies have focused on the differentiation of metabolic fingerprints within a single species following exposure to environmental stress. Ihssen and Egli (35) were able to distinguish between repressed and induced catabolic functions in E. coli when exposed to low concentrations of a mixed carbon and energy source pool. BIOLOG microtiter plates demonstrated that numerous catabolic functions were depressed under glucose or arabinose limited growth conditions, while cells grown in complex mixed chemostat showed a high level of catabolic flexibility as reflected by utilization of 43 different substrates. These results suggest that the BIOLOG assay has the ability to provide catabolic data from a pure culture after differing growth conditions.

In the current study, the BIOLOG system was evaluated as a tool to determine physiological differences in bacterial species after exposure to heat stress. The potential 
utilization of 95 different carbon substrates was used to determine if a change in metabolism occured as a result of exposure to heat stress. Differences in catabolic pathways can potentially be used to identify the need for specific carbon substrates due to the metabolic burden of synthesizing stringent response proteins of heat stressed cells and non-stressed cells. In combination with the BIOLOG system, the cultivation of cells on a selective and non-selective media was used to determine survivability and sublethal injury of the cells.

\section{Materials and Methods}

\subsection{Preparation and growth of test species}

Escherichia coli (ATCC 23559), Enterobacter sakazakii (ATCC 51329), and

Salmonella enterica serotype Typhimurium (ATCC 35987) were grown separately in 10 $\mathrm{ml}$ of trypticase soy broth (TSB) at $35^{\circ} \mathrm{C}$ for $24 \mathrm{~h}$. The respective test isolates were subcultured on trypticase soy agar (TSA) and incubated at $35^{\circ} \mathrm{C}$ for an additional $24 \mathrm{~h}$. A single colony was finally selected and grown in $50 \mathrm{ml}$ of TSB at $35^{\circ} \mathrm{C}$ for $24 \mathrm{~h}$ and used as the final test population.

\subsection{Heat stress}

Ten $\mathrm{ml}$ of the $50 \mathrm{ml}$ culture was centrifuged at $3020 \mathrm{~g}$ for $10 \mathrm{~min}$. The supernatant was removed, and the pellet was resuspended in $10 \mathrm{ml}$ of $0.1 \%$ peptone buffer and washed twice. One $\mathrm{ml}$ of washed cells was added to a $99 \mathrm{ml}$ control flask, held at room temperature, and a $99 \mathrm{ml}$ reaction flask tempered to $52^{\circ} \mathrm{C}$ (E. sakazakii and S. typhimurium) or $55^{\circ} \mathrm{C}$ (E. coli), containing $0.1 \%$ peptone buffer (initial population $\left.10^{7} \mathrm{CFU} / \mathrm{ml}\right)$. Cells from the control flask were immediately plated onto nonselective TSA, an appropriate selective medium, and into a BIOLOG GN microplate. Cells added 
to the reaction flask were plated immediately in order to establish a 0 -time count. The reaction flask was then placed into a $52^{\circ} \mathrm{C}\left(55^{\circ} \mathrm{C}\right.$ for $E$. coli $)$ incubator and samples were removed as a function of time $(15,30,60$, and $90 \mathrm{~min})$. Stressed cells were inoculated into BIOLOG GN plates and plated on nonselective and the appropriate selective media using a spread plate technique at each exposure time. Heat shock experiments were done in triplicate for each species tested.

\subsection{Survival and sublethal injury}

Tryptic soy agar (TSA) was used as a non-selective medium for all species permitting determination of overall survival (noninjured + injured cells) of the heat stress in the reaction flask. All species were plated onto MacConkey agar to serve as the selective medium permitting determination of the number of nonlethally injured survivors. $E$. sakazakii was additionally plated onto Oh and Kang medium (OK), and S. enterica serovar Typhimurium (S. typhimurium) was plated onto Salmonella -Shigella agar (SSA). Heat-stressed cells were plated in triplicate and incubated at $35^{\circ} \mathrm{C}$ for $24 \mathrm{~h}$. Following incubation, colonies were counted on the various media to determine overall survival and sublethal injury. Sublethal injury was calculated as the difference of viable counts obtained on MacConkey agar (selective agar) [as this was consistently used for all test species] and those obtained on TSA (nonselective agar), expressed as a percentage. Decimal reduction time (D-value) was estimated using standard regression analysis based on log linear models. For each species tested, a linear model for time versus log CFU of the counts was used to estimate the D-values. 


\subsection{Carbon source utilization patterns}

Carbon source utilization patterns of nonheated and thermally stressed cells were examined with a respiration assay based on BIOLOG GN MicroPlates. BIOLOG microplates were inoculated with the control and stressed cells $\left(10^{-2}\right.$ dilution $)$ after heat stress at $52^{\circ} \mathrm{C}$ for Enterobacter sakazakii and Salmonella typhimurium. E. coli exposed to $52^{\circ} \mathrm{C}$ did not demonstrate a sufficient decrease in cell counts to suggest a physiological change, therefore cells were exposed to $55^{\circ} \mathrm{C}$. Substrate utilization patterns were determined by comparing reduction of a tetrazolium dye in the 95 different well substrates vs. a control well (water). Absorbance data of the tetrazolium dye were collected at $595 \mathrm{~nm}$ using a spectrophotometer (SpectraMax 340PC). This wavelength was chosen as it provides maximum absorbance for tetrazolium violet (49). Absorbance values for wells containing carbon substrates were blanked against the control well. BIOLOG GN microplates were incubated at $35^{\circ} \mathrm{C}$ and read every $24 \mathrm{~h}$ for $96 \mathrm{~h}$.

Average well color development (AWCD) was determined by the differences between control (water) and substrate wells divided by 95. Significant difference was determined with the use of the t-test $(\mathrm{p}<0.05)$. Sole-source carbon utilization patterns were separated in guilds as described by Zak et al. (90). Guilds are created according to the chemical nature of the substrates and, therefore, provide additional analysis on utilization of specific groups of substrates (e.g. carbohydrates or amino acids) after exposure to heat stress. The two applications of AWCD and guilds were observed after $24 \mathrm{~h}$ incubation to allow for the most amount of color development without saturation levels being reached in some wells. Significance was calculated with the use of the t-test $(p<0.05)$. Finally, specific substrate utilization was observed by comparing the relative 
utilization for all 95 substrates individually in non-heated control cells to 90 min heatstressed cells.

\subsection{Statistical analyses}

Data from the BIOLOG microplates were taken from Soft MAX Pro (version

3.1.2 ) and transferred onto an Excel spreadsheet. The area under the color development curve is reported to be an alternative to avoid optical density differences because of differences in inoculum density (63). The color formation profile for the area under the curve is characterized by three summary statistics: 1) maximum value attained (asymptote), 2) time at which maximum value is attained (rate of utilization), and 3) time at which color development is half that of the maximum value attained (lag phase of utilization). Calculating the area under the curve was done using the formula provided by Guckert et al. (27), which uses the trapezoid rule to produce an estimate of the total area under the curve. This approach is particularly useful in determining differences between treatments in the maximum color development or in the rates of color development, both of which result in different areas under the time-course profile (28). Therefore, if a heatstressed cell had a longer lag period it would result in a smaller area, whereas, a nonheated control cell that had a faster rate and higher asymptote would result in a larger area. With this in mind, Preston-Mafham et al. (63), suggested that the kinetic parameters of maximum rate and maximum value attained are insensitive to inoculum densities when observing a pure culture. Once the area under the curve was calculated, substrate utilization differences between control cells and cells exposed to 90 min of heat stress were identified and the students t-test was used to determine significant statistical 
differences between substrates $(\mathrm{p}<0.05)$. Substrates demonstrating significance were then presented as percent difference in utilization.

\section{Results and discussion}

\subsection{Survival and injury following heat stress}

The D-values for all three species were determined using linear regression (Fig. 1.1). E. coli populations were observed to be the most heat resistant $\left(\mathrm{D}_{55}=45.25\right)$ (Fig. 1.1). E. sakazakii populations demonstrated the most sensitivity towards heat stress $\left(\mathrm{D}_{52}=38.91\right)$ (Fig. 1.1). On the other hand, S. typhimurium populations showed a $\mathrm{D}_{52}$ of 58.45 (Fig. 1.1). Comparing E. coli viable cell counts on TSA to MacConkey agar a sublethal injury rate of $90 \%$ was observed after 90 min (Fig. 1.2). Similarly, $S$. typhimurium demonstrated a 90\% sublethal injury rate (Fig. 1.4), while E. sakazakii showed the greatest amount of sublethal injury demonstrating a 97\% sublethal injury rate (Fig. 1.3). In addition to sublethal injury, a comparison of selective media was carried out to determine the effectiveness of Oh and Kang medium (OK) and SalmonellaShigella agar (SSA), when compared to MacConkey agar. No differences in viable cell counts were observed in E. sakazakii when comparing MacConkey agar to OK medium (Fig. 1.3). However, after 90 min of exposure to heat stress S. typhimuium demonstrated a one-log difference in viable cell counts between MacConkey agar and SSA, suggesting that the SSA medium may be less effective in isolating heat injured S. typhimurium cells (Fig. 1.4). 


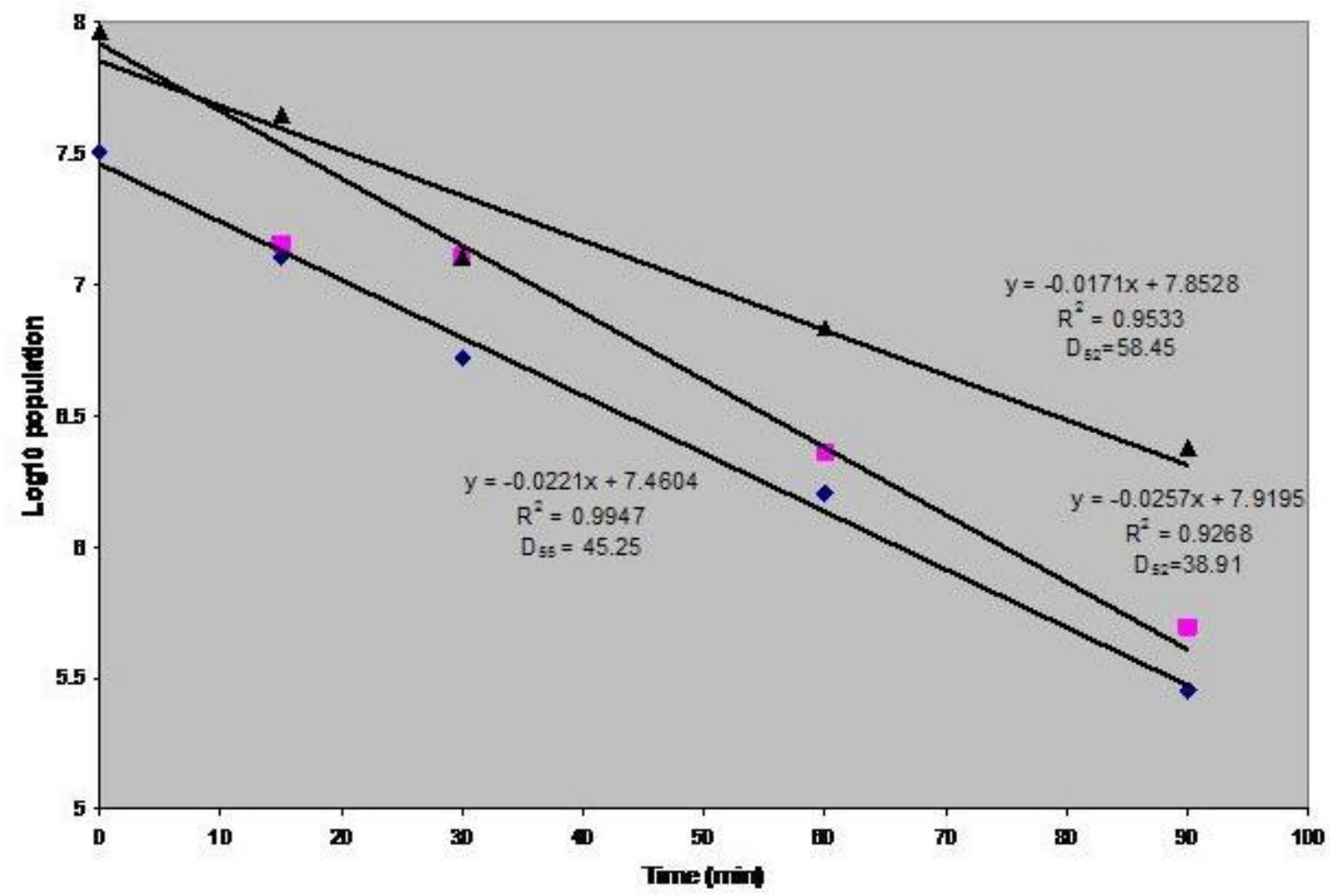

Fig. 1.1. D-value determination of thermally-stressed enteric bacteria.

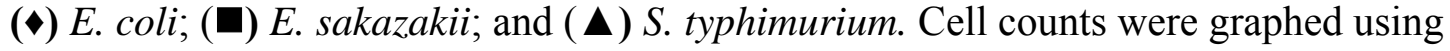
linear regression of the survival curve (triplicate TSA counts) to determine the slope. Each point represents the average of three independent experiments for all three bacterial species. 


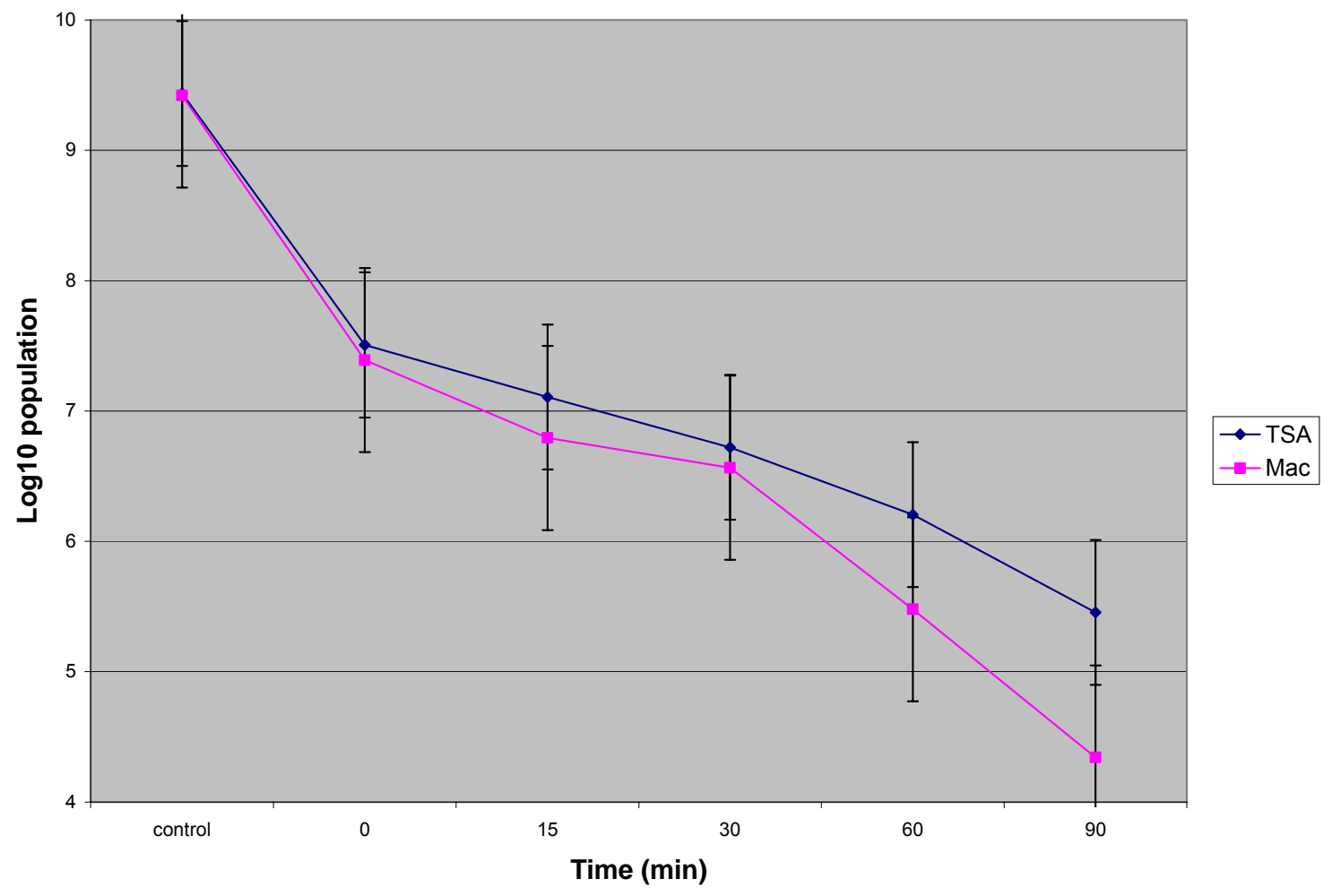

FIG 1.2. Survival curve of $E$. coli exposure to $52^{\circ} \mathrm{C}$ for $90 \mathrm{~min}$. Cells were plated in triplicate onto TSA $(\bullet)$ and MacConkey agar ( $(\mathbf{)}$. Control cells were plated after being placed into $99 \mathrm{ml}$ of $0.1 \%$ peptone at room temperature $\left(23^{\circ} \mathrm{C}\right)$. Cells exposed to heat stress were placed into $99 \mathrm{ml}$ of $0.1 \%$ peptone at $52^{\circ} \mathrm{C}$ and plated initially (time 0 ) and sequentially at 15, 30,60 and 90 min thereafter. Each point represents the average of three independent experiments. Bars represent the standard error. 


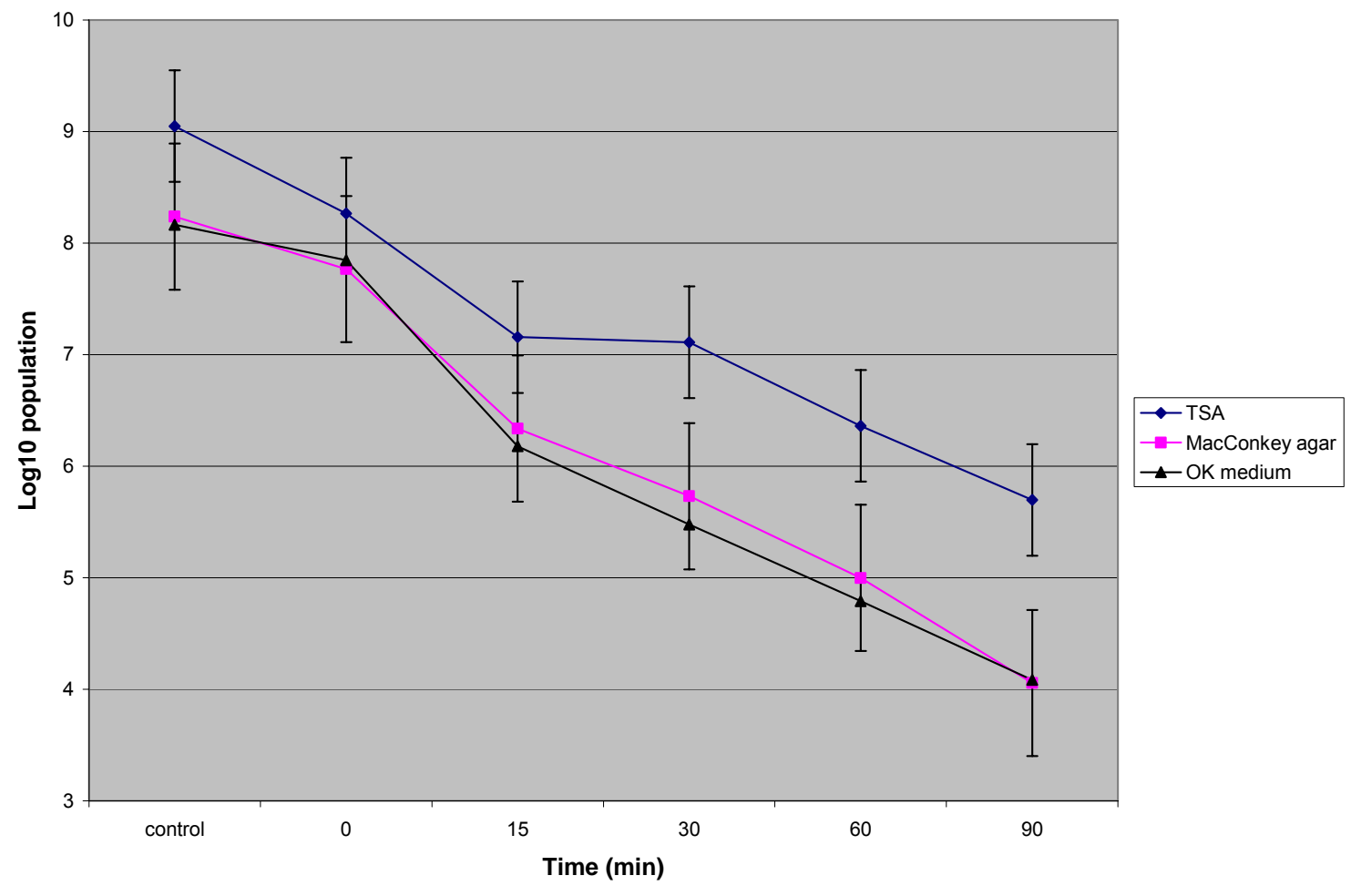

FIG 1.3. Survival curve of E. sakazakii exposure to $52^{\circ} \mathrm{C}$ for $90 \mathrm{~min}$.

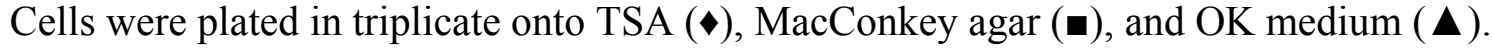
Control cells were plated after being placed into $99 \mathrm{ml}$ of $0.1 \%$ peptone at room temperature $\left(23^{\circ} \mathrm{C}\right)$. Cells exposed to heat stress were placed into $99 \mathrm{ml}$ of $0.1 \%$ peptone at $52^{\circ} \mathrm{C}$ and plated initially (time 0 ) and sequentially at $15,30,60$ and 90 min thereafter. Each point represents the average of three independent experiments. Bars represent the standard error. 


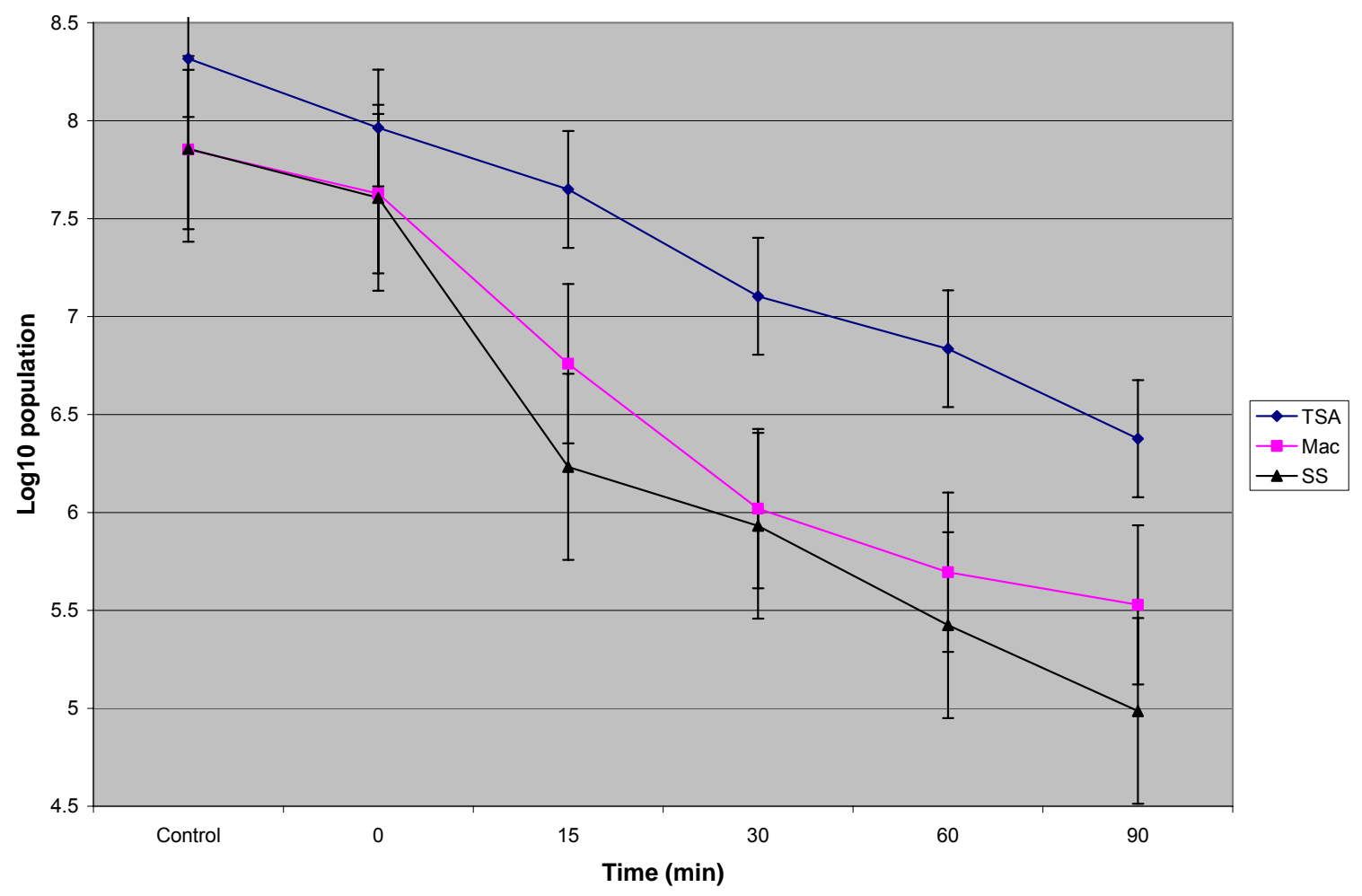

FIG 1.4. Survival curve of $S$. typhimurium after exposure to $52^{\circ} \mathrm{C}$ for 90 min. Cells were plated in triplicate onto TSA ( $\bullet)$, MacConkey agar $(\boldsymbol{\bullet})$, and ( $\mathbf{\Lambda})$. Control cells were plated after being placed into $99 \mathrm{ml}$ of $0.1 \%$ peptone at room temperature $\left(23^{\circ} \mathrm{C}\right)$. Cells exposed to heat stress were placed into $99 \mathrm{ml}$ of $0.1 \%$ peptone at $52^{\circ} \mathrm{C}$ and plated initially (time 0 ) and sequentially at $15,30,60$ and 90 min thereafter. Each point represents the average of three independent experiments. Bars represent the standard error. 
D-values (decimal reduction time for a 1-log reduction at a specific temperature) for all three species are summarized in Table 1.1. The observed $\mathrm{D}_{55}$ of 45.25 for E. coli, is comparable to the reported observations of Riordan et al. (69). The $\mathrm{D}_{52}$ of 54.76 for $E$. sakazakii observed by Nazarowec-White and Farber (59) is substantially higher than the $\mathrm{D}_{52}$ of 38.91 in the current study (Table 1.1). However, Nazarowec-White and Farber (59) examined the thermal inactivation of E. sakazakii in infant formula which is known to contain a high lipid content, which may have aided in protection of the stressed cells. The $\mathrm{D}_{52}$ of 58.45 that was observed for S. typhimurium is considerably higher than the $\mathrm{D}_{52}$ of 21.3 as reported by Bunning et al. (12) (Table 1.1). Differences in the observed Dvalue could be due to the clinical strain (42ScBs) used by Bunning et al. (12) whereas this study used a type strain (ATCC 35987). Nazarowec-White and Farber (59) suggested that E. sakazakii was more thermotolerant than many other Enterobacteriaceae in infant formula, however our results suggest that E. sakazakii is less thermotolerant than E. coli and S. typhimurium in peptone buffer. 
TABLE 1.1. Decimal reduction times (min) for three test organisms following heat stress for $90 \mathrm{~min}$

\begin{tabular}{lcc}
\hline \multicolumn{1}{c}{ Test Organism } & Stress Temperature & D-value $^{\mathrm{a}}$ \\
\hline E. coli & $55^{\circ} \mathrm{C}$ & $45.25 \pm 9.40$ \\
S. typhimurium & $52^{\circ} \mathrm{C}$ & $58.45 \pm 6.64$ \\
E. sakazalii & $52^{\circ} \mathrm{C}$ & $38.91 \pm 8.45$ \\
\hline
\end{tabular}

${ }^{\mathrm{a}} \pm$ standard deviation 


\subsection{Differences in substrate utilization of control cells compared to heat stressed cells as determined by the BIOLOG plate system with the use of AWCD and guild groupings}

Simultaneous with cell count determinations on a selective and nonselective media, BIOLOG GN microtiter plates were inoculated with control and heat stressed cells. Average well color development (AWCD) was calculated by averaging the absorbance readings for all 95 substrates (Table 1.2). All three organisms tested showed a gradual decrease in AWCD with increased time of exposure to heat stress (Table 1.2). However, only E. coli and S. typhimurium were observed to have significantly different AWCD by heat-stressed cells when compared to non-heated control cells. A reason for this may be the large variance in AWCD observed in E. sakazakii cells exposed to $90 \mathrm{~min}$ of heat stress. It was previously reported (16) that substantial variation in the thermal resistance of E. sakazakii isolates was observed, with a 20 -fold differential between the most thermal resistant to the least thermal resistant strain. 
TABLE 1.2. Average well color development (AWCD) of the three test organisms during heat stress

\begin{tabular}{lccc}
\hline & \multicolumn{3}{c}{ AWCD $^{\mathrm{a}}$} \\
\cline { 2 - 4 } $\begin{array}{l}\text { Exposure time } \\
\text { (min) }\end{array}$ & E. coli & E. sakazakii & S. typhimurium \\
\hline Control & 0.753 & 0.730 & 0.562 \\
0 & 0.748 & 0.728 & 0.554 \\
15 & 0.667 & 0.689 & 0.542 \\
30 & $0.697^{*}$ & 0.663 & 0.533 \\
90 & $0.619^{*}$ & 0.567 & $0.467^{*}$ \\
\hline
\end{tabular}

${ }^{a}$ Average well color development after 24 hour incubation on BIOLOG GN microplates ${ }^{\mathrm{b}}$ Cells placed into $99 \mathrm{ml}$ of $0.1 \%$ peptone at $25^{\circ} \mathrm{C}$

* t-test $(\mathrm{p}<0.05)$ shows significance when compared to control 
BIOLOG guilds are characterized according to specific chemical groups:

carbohydrates, carboxylic acids, polymers, amines, amino acids, and miscellaneous (90). Examination of utilization patterns related to substrate guilds may enable differentiation of repressed and induced catabolic functions as a result of being exposed to heat stress. E. coli showed no significant differences in guild substrate utilization patterns; however the carboxylic acid and amino acid guild demonstrated the largest difference in utilization between non-heated control cells and 90 min heat-stressed cells (Fig 1.5). Similar results were seen in E. sakazakii, which was observed to demonstrate a gradual decrease in utilization with increased exposure to heat stress (Fig. 1.6). In addition, no significant differences were observed, however the amino acid showed the greatest change between control, initially heat-stressed (0) and 90 min heat-stressed cells.

S. typhimurium cells initially heat-stressed ( 0 time) demonstrated differences in substrate utilization of the polymer guild when compared to non-heated control, 30, and 90 min heat-stressed cells (Fig 1.7). In addition, both initially and 15 min heat-stressed cells were observed to have more total color formation in all guilds than non-heated control cells. Reasons for this increase in substrate utilization of guilds for cells initially heat stressed and $15 \mathrm{~min}$ heat stressed is undetermined at this time. Non-heated control cells did demonstrate a difference in the utilization of amines when compared to $90 \mathrm{~min}$ heat-stressed cells. 


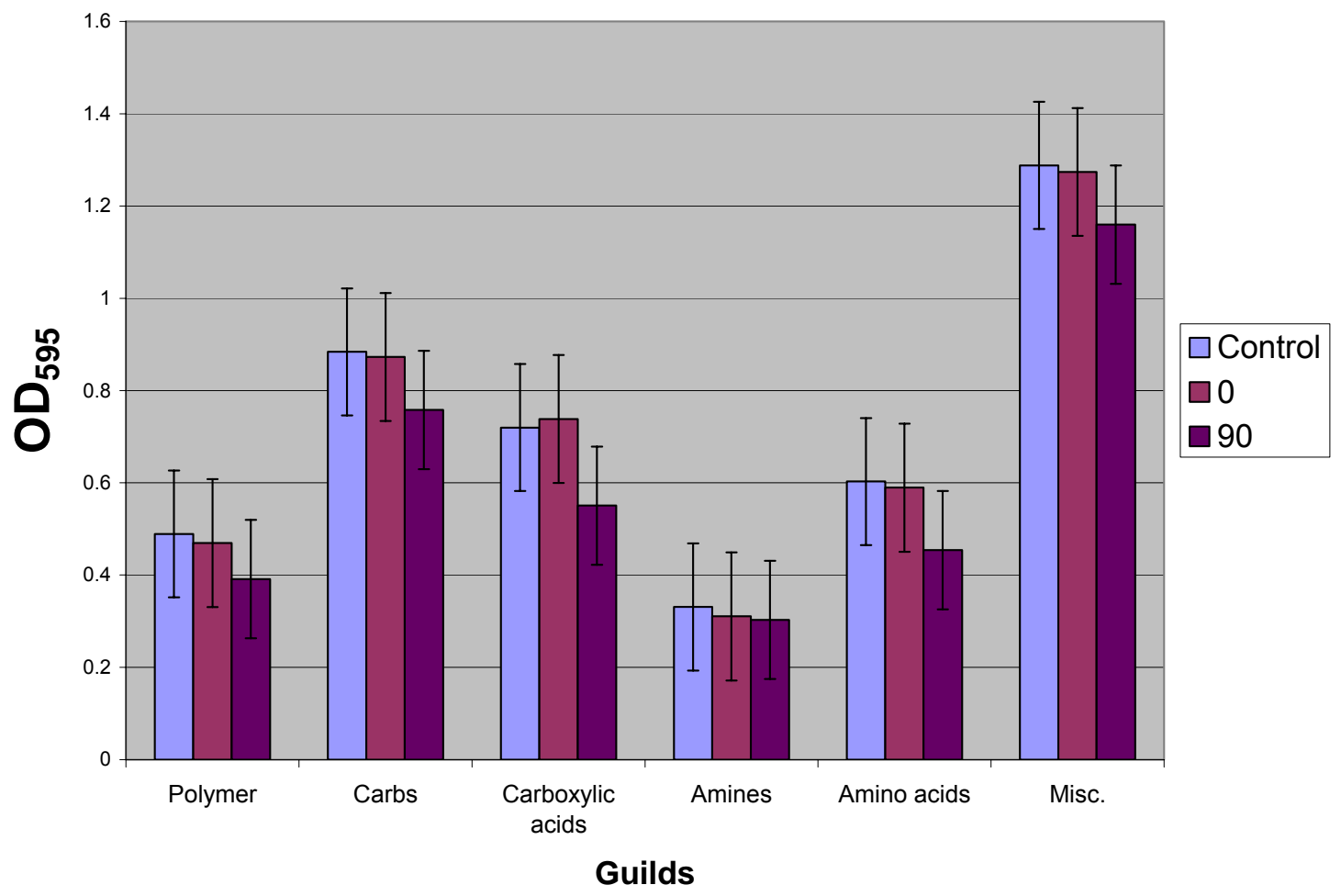

FIG. 1.5. E. coli average AREA substrate utilization of guilds. BIOLOG GN microtiter plates segregated into the six guilds as described by Zak et al. (1994). Color formation was read after $24 \mathrm{~h}$ incubation. Bars represent standard error. 


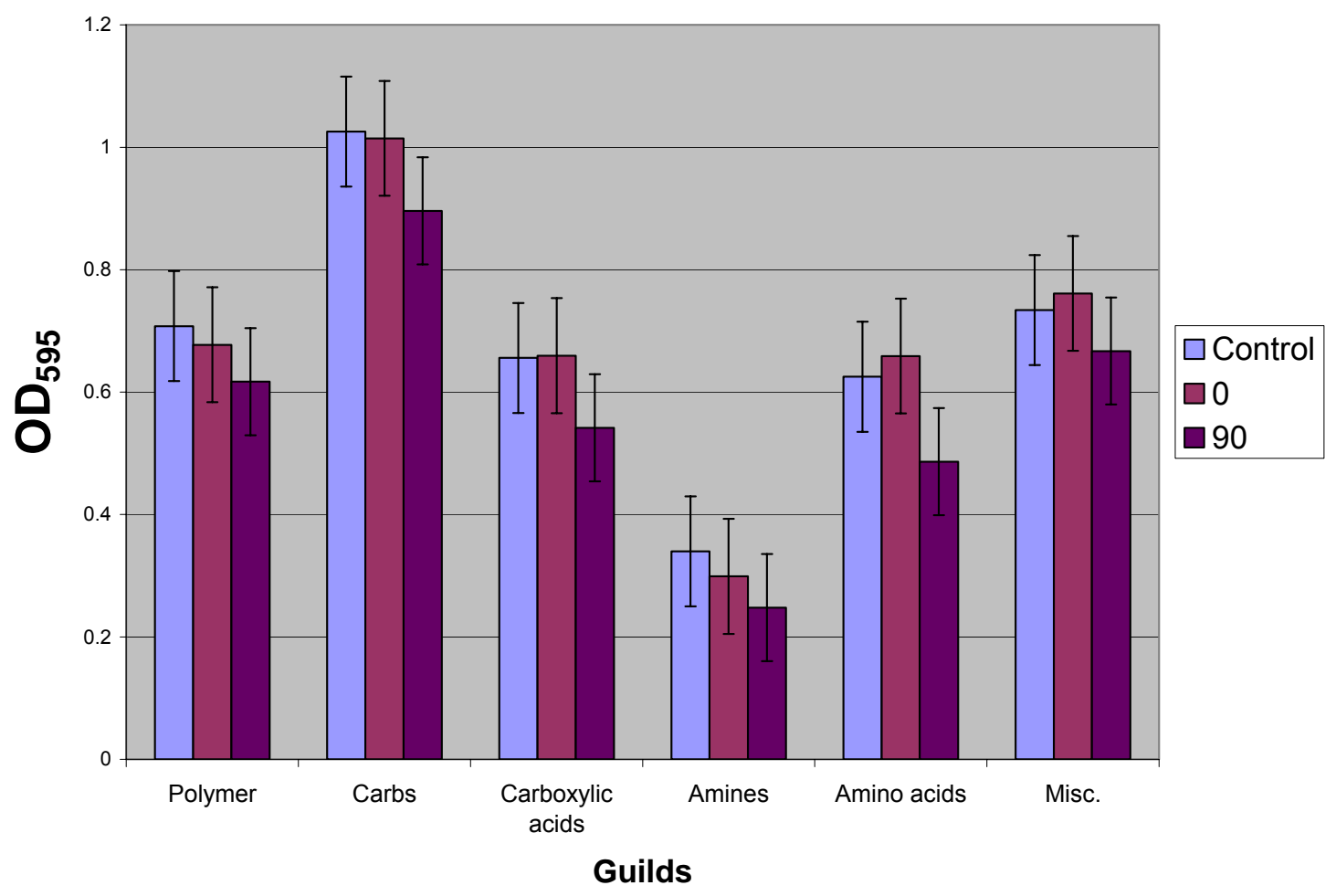

FIG. 1.6. E. sakazakii average AREA substrate utilization of guilds. BIOLOG GN microtiter plates segregated into the six guilds as described by Zak et al. (1994). Color formation was read after $24 \mathrm{~h}$ incubation. Bars represent standard error. 


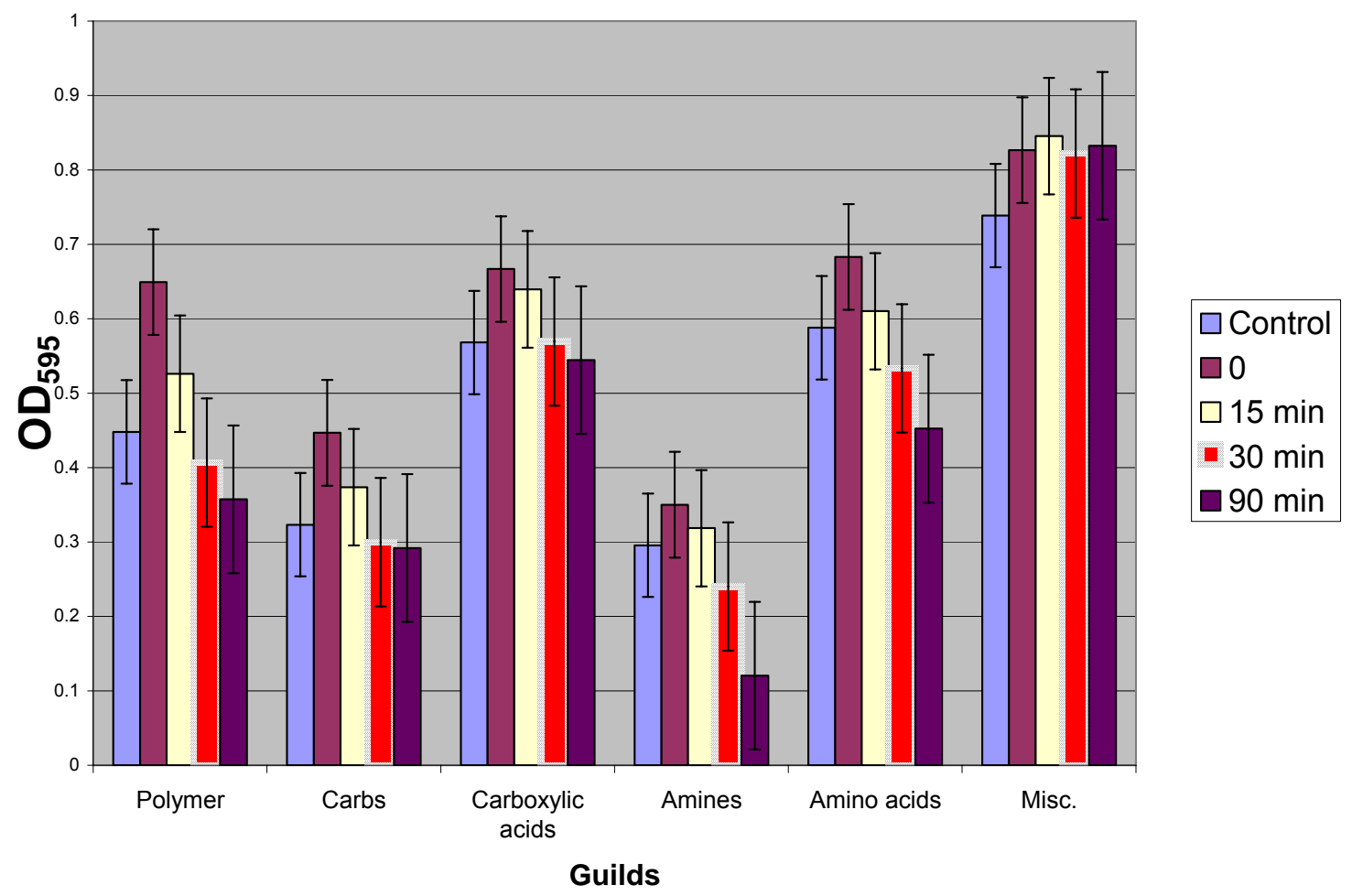

FIG. 1.7. S. typhimurium average AREA substrate utilization of guilds. BIOLOG GN microtiter plates segregated into the six guilds as described by Zak et al. (1994). Color formation was read after $24 \mathrm{~h}$ incubation. Bars represent standard error. 


\subsection{Differences in specific substrate utilization of heat-stressed cells as determined by the BIOLOG plate system}

Specific substrate utilization differences in heat-stressed bacteria, expressed as percent differences in the average AREA for each species, are given in Table 1.3. The use of a kinetic approach, such as the area under the curve in BIOLOG data analysis, is reportedly insensitive to differing inoculum densities of a pure culture up to four orders of magnitude lower than the suggested density of $3 \times 10^{8}$ cells $/ \mathrm{ml}(49)$. E. coli exposed to heat stress for 90 min showed a significant $(\mathrm{p}<0.05)$ decrease in utilization of five substrates: $\alpha$-D-glucose, L-rhamnose, D-glucose-6-phosphate, D-trehalose, and L-alanine when compared to control cells (Table 1.3). The metabolism of $\alpha$-D-glucose, Lrhamnose, D-glucose-6-phosphate, and D-trehalose results in the production of pyruvate which subsequently enters the citric acid cycle for the production of NADH, FADH2, and ATP (41). These observations may suggest that catabolic regulation and the stringent response are interconnected. Conversely, no increases in substrate utilization for $90 \mathrm{~min}$ heat-stressed cells compared to control cells were observed. Apparently, E. coli exposed to heat stress results in the repression of the catabolic pathways leading to pyruvate synthesis.

E. sakazakii cells exposed to heat stress for 90 min showed a decrease in the utilization of L-arabinose, L-ornithine, and b-methyl-glucoside compared to control cells (Table 1.3). L-arabinose is known to be a precursor of the pentose-phosphate pathway, which is used to synthesize nucleotides and aromatic amino acids (13). Following 90 min exposure to heat, E. sakazakii demonstrated an increased utilization of xylitol, adonitol, and glycogen (Table 1.3). Both xylitol and adonitol are precursors in the pentose-phosphate pathway (PPP). Of interest is the observed decreased utilization of L- 
arabinose and increased utilization of xylitol and adonitol in 90 min heat-stressed $E$.

sakazakii (Table 1.3). Adonitol utilization is well known for several enteric bacteria, such as Klebsiella spp. and E. coli, whereas very few enteric bacteria are able to metabolize xylitol (74). The observation that E. sakazakii utilizes L-arabinose more prior to heat stress and xylitol and adonitol more after heat stress may represent an unexplained metabolic polymorphism due to exposure to heat stress. Future studies are needed to determine reasons for this observation of increased adonitol and xylitol catabolism in heat-stressed cells.

As reported previously (Table 1.2), S. typhimurium demonstrated an unexpected increase in AWCD after initial exposure to heat and after 15 min of stress when compared to control cells. Nevertheless, significant differences for specific substrates were observed between the control cells and cells exposed to heat stress for $90 \mathrm{~min}$. S. typhimurium exposed to 90 min of heat stress demonstrated a decrease in utilization for tween 80 and an increase in utilization of succinic acid mono-methyl, L-ornithine, and bromosuccinic acid (Table 1.3). The substrates succinic acid mono-methyl and bromosuccinic acid are degraded into succinate which is then transferred as an intermediate of the TCA cycle. In addition, 90 min heat-stressed cells also demonstrated an increased utilization of L-ornithine which can be used as either a carbon or nitrogen source. As a carbon donor, L-ornithine is metabolized into arginine and subsequently succinate for use in the TCA cycle, similar to succinic acid mono-methyl and bromosuccinic acid. As a nitrogen source, L-ornithine may be catabolized into two molecules of ammonia (67). 
Substrate utilization differences for $15 \mathrm{~min}$ and 90 min heat-stressed $S$.

typhimurium were compared to non-heated control cells (Table 1.4). Heat-stressed $S$. typhimurium demonstrated a similarity of increased utilization of succinic acid monomethyl and L-ornithine when compared to non-heated control cells. This observation demonstrates that the BIOLOG microplate system is consistent in identifying utilization differences between heat-stressed and non-heated control cells.

\section{Summary}

In the present study, the physiological changes of three different enteric bacteria exposed to heat stress were monitored using conventional plate count methodology and the BIOLOG identification system. Our results indicate the BIOLOG system may be valuable as a supplement to traditional assays for the determination of physiological changes to environmentally stressed bacteria. Specific observations include:

Of the three enteric bacteria tested, E. coli demonstrated the greatest thermotolerance $\left(\mathrm{D}_{55}=45.25\right)$, followed by $\mathrm{S}$. typhimurium $\left(\mathrm{D}_{52}=58.45\right)$ and E. sakazakii $\left(\mathrm{D}_{52}=38.91\right)$. In addition, cells were observed to experience sublethal injury when exposed to heat stress, as reflected by the differences in viable cell counts on TSA compared to MacConkey agar. Furthermore, MacConkey agar proved to be a more reliable selective medium compared to Salmonella-Shigella agar for isolation of heat-injured S. typhimurium. 
TABLE 1.3. Utilization of specific BIOLOG substrates by heat-stressed $\left(52^{\circ} \mathrm{C}\right.$ for $90 \mathrm{~min}$ ) bacteria species compared to substrate utilization of non-heated control cells

\begin{tabular}{lll}
\cline { 2 - 3 } Organism & \multicolumn{2}{c}{ Substrates demonstrating $^{\mathrm{a}}$} \\
\cline { 2 - 3 } E. coli & Increased utilization & Decreased utilization \\
& & $\alpha$-D-glucose (17\%) \\
& L-rhamnose (14\%) & D-glucose-6-phosphate (14\%) \\
& D-trehalose (13\%) \\
L. typhimurium & L-alanine (9\%) \\
& Succinic acid mono methyl (70\%) & Tween $80(24 \%)$ \\
& L-ornithine (40\%) & \\
& Bromosuccinic acid (25\%) & \\
E. sakazakii & Xylitol (53\%) & L-ornithine (15\%) \\
& Adonitol (29\%) & $\beta$-methyl-glucoside (13\%) \\
& Glycogen (12\%) & \\
\hline
\end{tabular}

${ }^{a}$ Those substrates indicating significant difference in utilization $(p<0.05)$ as determined using the AREA formula (expressed as percent difference in parentheses) 
TABLE 1.4. Utilization of specific BIOLOG substrates by heat-stressed Salmonella typhimurium compared to substrate utilization of non-heated control cells.

\begin{tabular}{|c|c|c|}
\hline \multirow[b]{2}{*}{ Comparison/heat stress } & \multicolumn{2}{|c|}{ Substrates demonstrating $^{\mathrm{a}}$} \\
\hline & Increased utilization & Decreased utilization \\
\hline 15 min heat stress & $\begin{array}{l}\text { Succinic acid mono methyl } \\
(76 \%) \\
\text { L-ornithine }(63 \%)\end{array}$ & \\
\hline 90 min heat stress & $\begin{array}{l}\text { Succinic acid mono methyl } \\
(70 \%) \\
\text { L-ornithine }(40 \%) \\
\text { Bromosuccinic acid }(25 \%)\end{array}$ & Tween $80(24 \%)$ \\
\hline
\end{tabular}


- Application of AWCD was found to be a more effective tool than guild groupings for purposes of monitoring physiological changes of heat-stressed enteric bacteria. Observed differences in AWCD were consistently demonstrated in all trials.

- Additionally, the use of specific substrate utilization demonstrated notable differences between non-heated control and 90 min heat-stressed cells in all three bacterial species. In addition, differences in substrate utilization were observed to be species specific.

- Differences in AWCD and alterations in the utilization of specific substrates suggest that the BIOLOG microplate system may be a useful technique to identify physiological changes in heat-stressed cells. A better understanding of the metabolic capabilities of heat-stressed cells as determined with the BIOLOG system, could result in modification of current selective media to improve recovery of sublethally injured bacteria from the environment. 
5. Appendix 


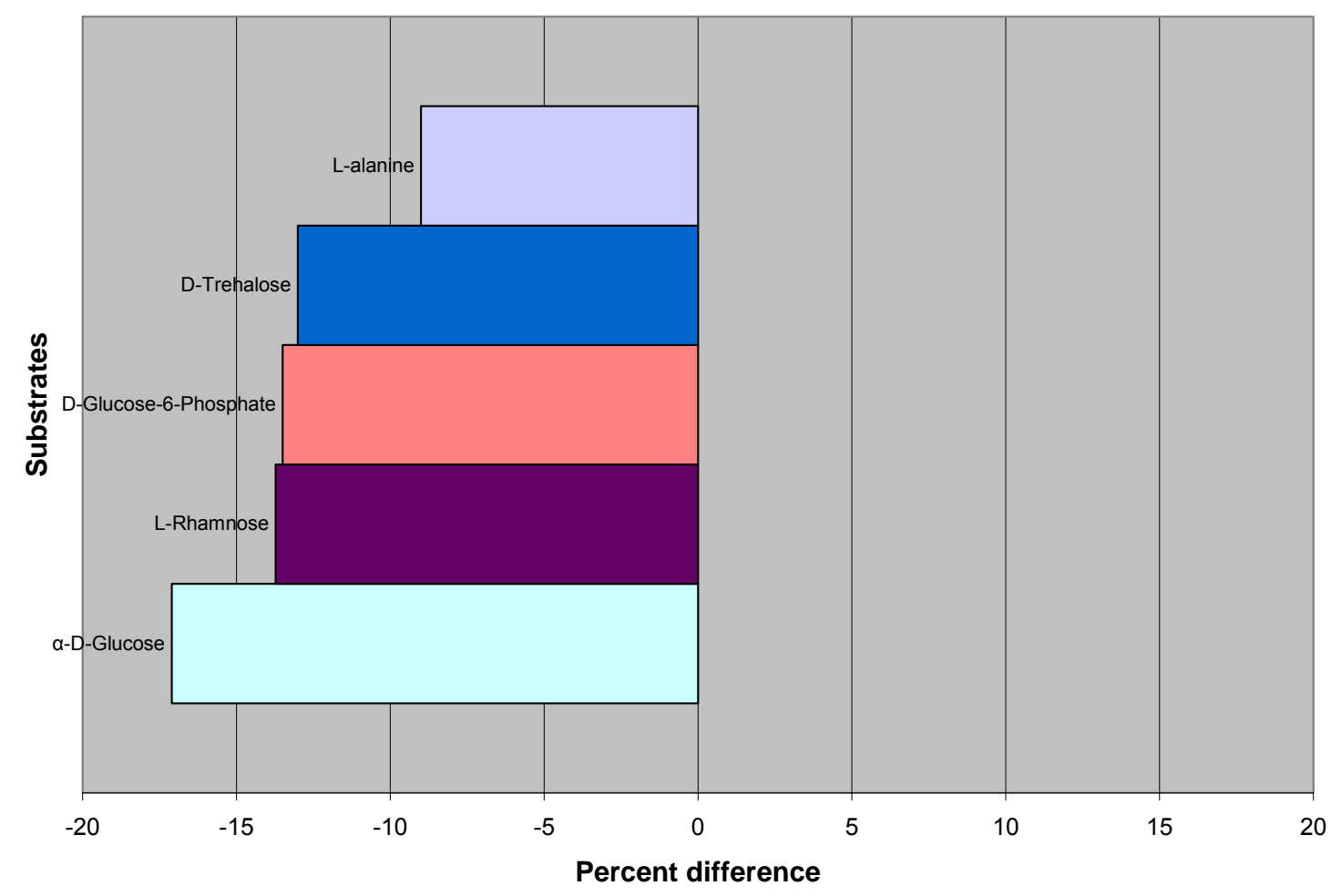

FIG 1.8. Substrate utilization differences for $E$. coli after $90 \mathrm{~min}$ of heat stress. Percent difference in substrate utilization of cells exposed to $55^{\circ} \mathrm{C}$ for $90 \mathrm{~min}$ was compared to substrate utilization of control cells. Substrate utilization was determined using the AREA formula. 


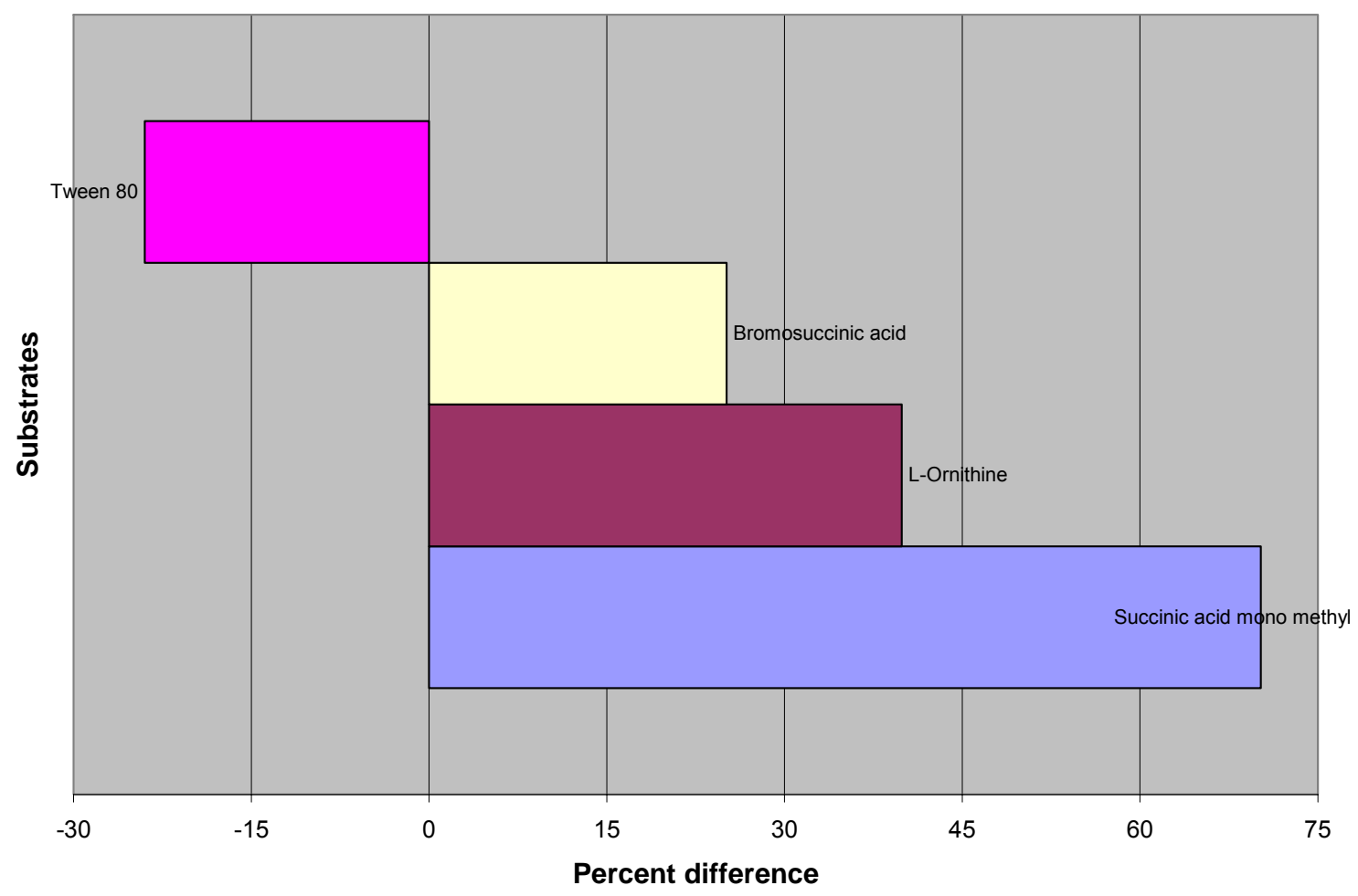

FIG 1.9. Substrate utilization differences for S. typhimurium after 90 min of heat stress. Percent difference in substrate utilization of cells exposed to $52^{\circ} \mathrm{C}$ for 90 min compared to substrate utilization of control cells. Substrate utilization was determined using the AREA formula. 


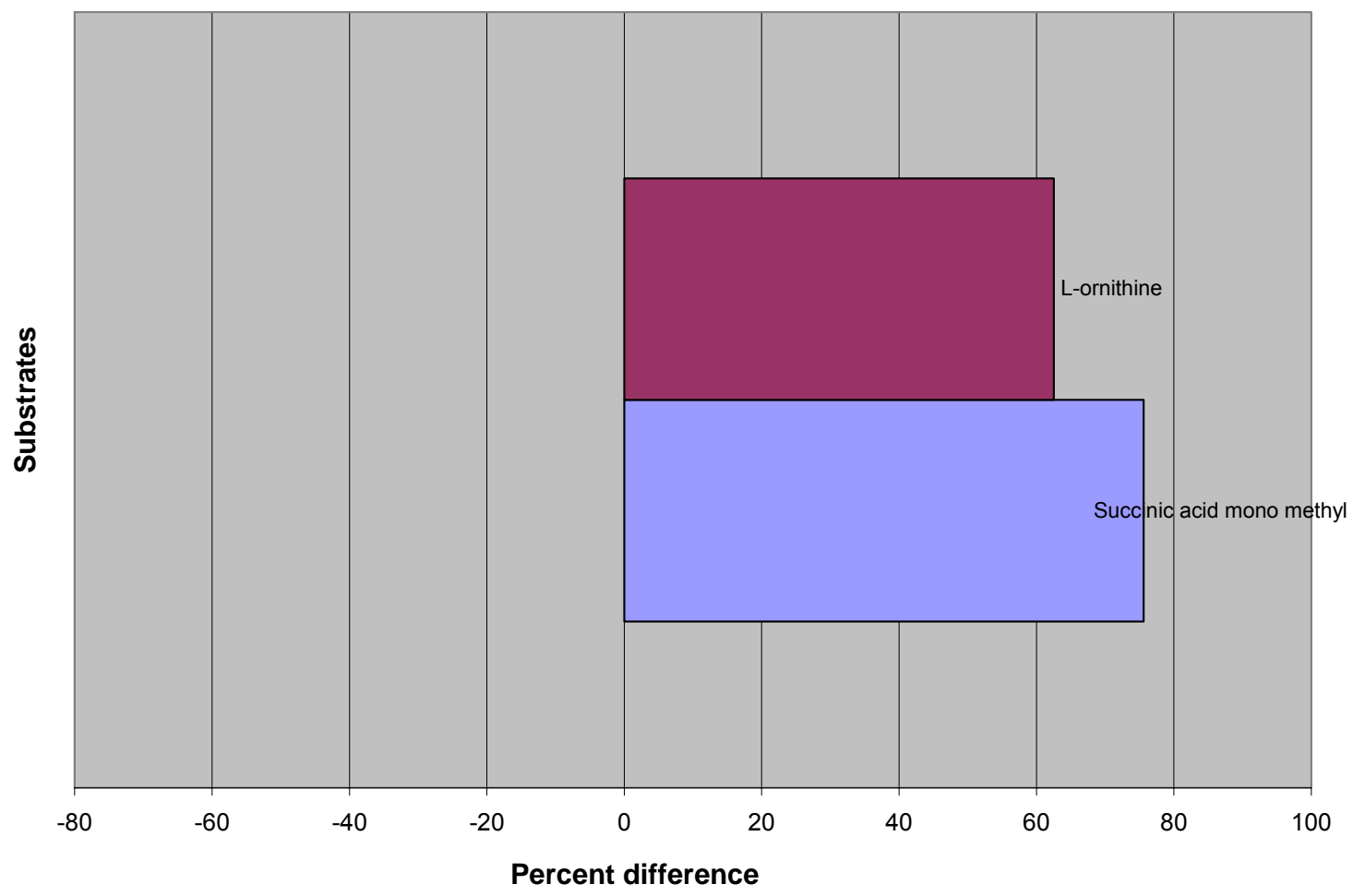

FIG 1.10. Substrate utilization differences for S. typhimurium after 15 min of heat stress. Substrate utilization percent difference in cells exposed to stress for 15 min was compared to substrate utilization of control cells. Substrate utilization was determined using the AREA formula. 


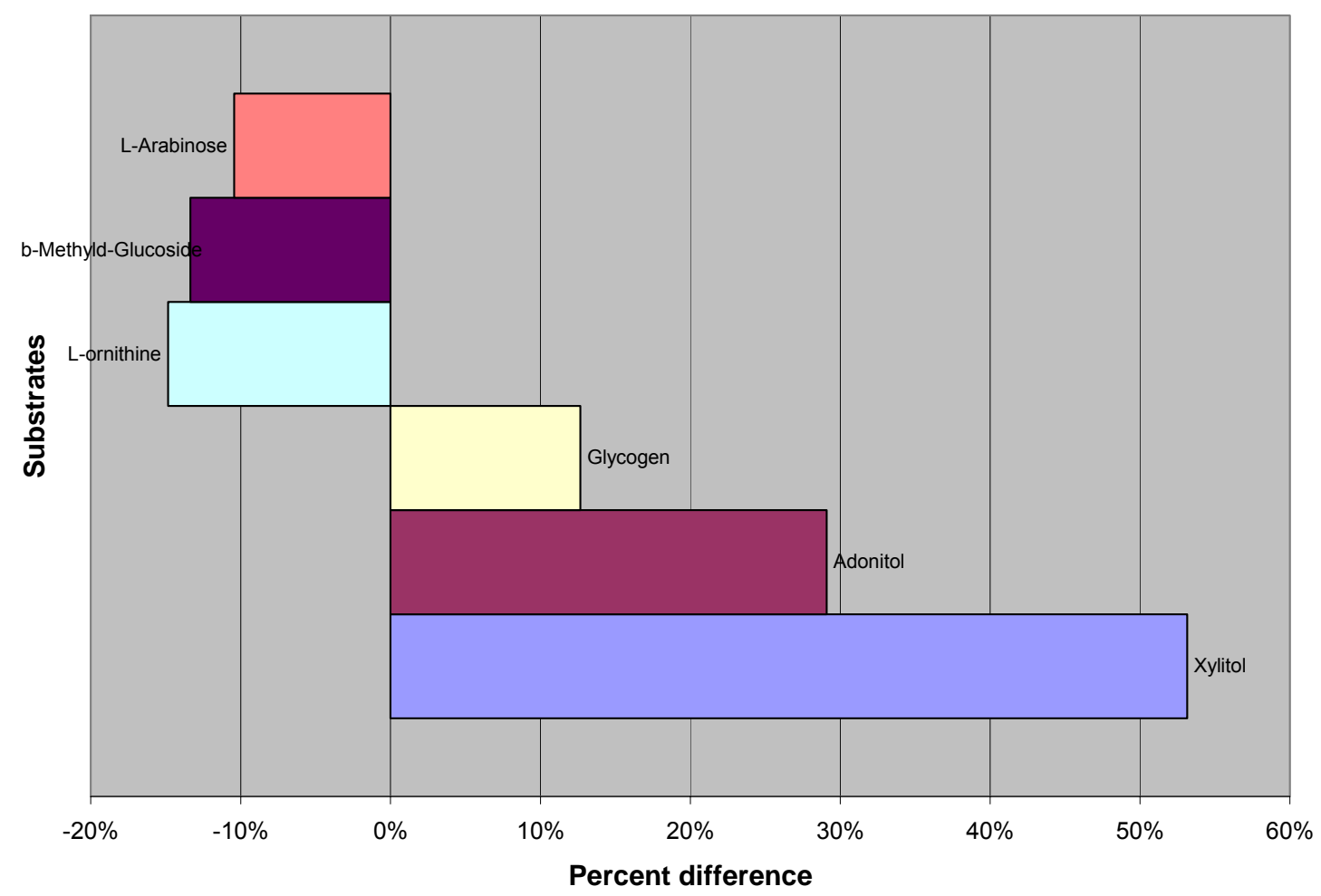

FIG. 1.11 Substrate utilization differences for E. sakazakii after $90 \mathrm{~min}$ of heat stress. Percent difference in substrate utilization of cells exposed to $52^{\circ} \mathrm{C}$ for 90 min was compared to substrate utilization of control cells. Substrate utilization was determined using the AREA formula. 


\section{Chapter 2:}

Evaluation of the physiological response of thermallystressed Enterobacter sakazakii with the BIOLOG microplate system as influenced by antecedent growth conditions 


\section{Introduction}

Enterobacter sakazakii, a gram-negative bacterium belonging to the family Enterobacteriaceae, was characterized by Farmer et al. (22). It is considered an emerging opportunistic pathogen and has been associated with meningitis and necrotizing enteritis in low birth weight and immuno-compromised babies (6). The source of infection is most commonly associated with dried infant formula. Since powdered infant formulas are pasteurized prior to production, contamination of such formulas may be a result of the post-production environment or improper storage (20). Although studies have failed to identify an environmental source, it has been isolated from a variety of foods and environments such as ground meat, surface water, soil, domestic animals, and thermal mineral water springs (36). Iversen et al. (37) suggested that plant material is a likely habitat based on the physiological features of the bacterium. These physiological features include the production of a yellow pigment, capsular and fimbriae formation, and the ability to resist desiccation during long dry periods. These factors may aid in the protection and survival of E. sakazakii in a dynamic environment, such as plant surfaces (57).

Given the potentially wide range of environments for E. sakazakii, it is possible that growth at different temperatures and/or under different nutrient conditions could potentially cause physiological changes affecting how the organism adjusts to subsequent heat stress. The classical approach to monitoring response of a bacterium to an environmental stress is to culture the test organism under controlled laboratory conditions at the optimum temperature and nutrients for growth. Unfortunately, optimum growth conditions may not accurately reflect in situ conditions. It has been well documented that 
antecedent growth conditions can alter the response of an organism to disinfection agents $(5,78,80)$; thus, it would seem plausible that differences in pre-growth conditions could effect a bacterium's response to heat shock.

In the current study, the BIOLOG microplate system was used to monitor physiological changes of heat-stressed E. sakazakii as related to pre-growth culture conditions. The use of the BIOLOG identification system was originally evaluated by Miller and Rhoden (55) as a method to correctly identify clinical and environmental isolates. The BIOLOG microtiter plate determines identity based on the exchange of electrons produced during utilization of a carbon substrate and subsequent respiration, leading to the reduction of a tetrazolium-based color change. The microtiter plate evaluates the ability of an organism to oxidize a panel of 95 different carbon sources, ranging from organic acids to sugars. In theory, different species should produce an individual pattern of positive purple wells which would make up a "metabolic fingerprint" (26). Ihssen and Egli (35) were able to distinguish between repressed and induced catabolic functions in E. coli which was exposed to low concentrations of a mixed carbon and energy source pool. By the use of BIOLOG microtiter plates it was demonstrated that numerous catabolic functions were repressed under glucose or arabinose limited growth conditions, while cells grown in complex mixed chemostat cultures showed a high level of catabolic flexibility by oxidizing 43 different substrates (35). These results suggest that the BIOLOG assay has the ability to provide catabolic data for a specific bacterium after differing growth conditions.

The BIOLOG microplate system was used in the present study to assess differences in substrate utilization of heat-stressed E. sakazakii incubated under different 
pre-growth conditions. Examination of the influence of different antecedent growth conditions, such as may occur in the natural environment, may allow for a more realistic evaluation of those substrates utilized by the bacterium following thermal stress.

\section{Materials and Methods}

\subsection{Antecedent growth conditions}

E. sakazakii (ATCC 51329) was incubated at $35^{\circ} \mathrm{C}$ for $24 \mathrm{~h}$ in TSB (defined as optimum conditions) before being exposed to heat shock as described previously (see Chapter 1). To determine if growth in a non-optimum environment affects response to heat shock, E. sakazakii was grown in $50 \mathrm{ml}$ of $1 / 10$ strength $\mathrm{TSB}$ at $35^{\circ} \mathrm{C}$ and in $50 \mathrm{ml}$ of TSB at $25^{\circ} \mathrm{C}$ for $24 \mathrm{~h}$ (Table 2.1). A $10 \mathrm{ml}$ aliquot was centrifuged at $3020 \mathrm{xg}$ for 10 min, washed, and exposed to heat stress at $52^{\circ} \mathrm{C}$, described in Chapter 1. Cells were harvested and heat-stressed as described previously (Chapter 1).

\subsection{Specific growth rate}

Specific growth rates (Table 2.1) were determined for the three antecedent growth conditions (TSB at $35^{\circ} \mathrm{C}$; TSB at $25^{\circ} \mathrm{C}$; and $1 / 10$ strength $\mathrm{TSB}$ at $35^{\circ} \mathrm{C}$ ) using a spectrophotometer (SpectraMax 340PC). Absorbance (OD660nm) was recorded every hour for 20 hours. Absorbance readings were calibrated by using a non-inoculated tube of TSB and 1/10 TSB for the respective cultures. Generation time (G) was calculated by determining the duration of exponential growth ( $\mathrm{t}$ ) and division of that time period by the number of generations (n) that occurred during exponential growth. Specific growth rate ( $\mu$ ) was subsequently determined by taking 1 over $\mathrm{G}(\mu=1 / \mathrm{G})$. 
TABLE 2.1. Enterobacter sakazakii growth conditions and specific growth

rate.

\begin{tabular}{cccc}
\hline \multicolumn{2}{c}{ Growth Conditions } & & \\
\cline { 1 - 1 } Temperature & TSB concentration & & Specific growth rate \\
\hline $35^{\circ} \mathrm{C}^{2}$ & $100 \%$ & & $2.30 \mathrm{~h}^{-1}$ \\
$25^{\circ} \mathrm{C}^{b}$ & $100 \%$ & & $1.99 \mathrm{~h}^{-1}$ \\
$35^{\circ} \mathrm{C}^{b}$ & $10 \%$ & & $1.91 \mathrm{~h}^{-1}$ \\
\hline
\end{tabular}

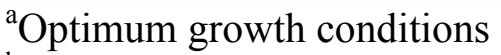

${ }^{\mathrm{b}}$ Non-optimum growth conditions 


\subsection{Observation of cell survival and sublethal injury}

E. sakazakii cells were plated onto TSA in order to calculate the D-values (calculated as previously described in Chapter 1) to compare thermotolerance of the cells grown under optimum conditions versus non-optimum conditions. In addition, survivors of heat stress were plated onto MacConkey agar to calculate sublethal injury, expressed as a percentage, as described previously (Chapter 1).

\subsection{Carbon source utilization patterns}

Carbon source utilization patterns of non-heated control and thermally-stressed cells cultured under the three antecedent growth conditions were examined with BIOLOG GN microtiter plates as described previously in Chapter 1. To determine the effect of growing E. sakazakii at non-optimum conditions (1/10 TSB @ $35^{\circ} \mathrm{C}$ and TSB @ $25^{\circ} \mathrm{C}$ ) had on substrate utilization patterns, cells grown at these conditions were compared to cells grown at optimum conditions (TSB @ $\left.35^{\circ} \mathrm{C}\right)$. Absorbance data were collected at $595 \mathrm{~nm}$ using a spectrophotometer (SpectraMax 340PC). BIOLOG microtiter plates were incubated at $35^{\circ} \mathrm{C}$ and read every $24 \mathrm{~h}$ for $96 \mathrm{~h}$. Average well color development (AWCD) was determined by the average absorbance levels of all 95 substrates for each reading. Sole-source carbon utilization patterns were separated in guilds as described by Zak et al. (90). Guilds are created according to the chemical nature of the substrates and therefore provide additional analysis on utilization of specific types of substrates after exposure to heat stress.

\subsection{Statistical analysis}

Data from the BIOLOG microplates were taken from Soft MAX Pro (version 3.1.2) and transferred onto an Excel spreadsheet. The final reading was used to calculate 
the area under the curve (AREA) as described previously in Chapter 1. Students t-test was used to determine significant difference $(\mathrm{p}<0.05)$ between substrates of interest.

\section{Results}

\subsection{Specific growth rate}

E. sakazakii had a specific growth rate of $2.3 \mathrm{~h}^{-1}$ when incubated at $35^{\circ} \mathrm{C}$ and grown in full strength TSB (Table 2.1). Incubation at $25^{\circ} \mathrm{C}$ in full strength TSB resulted in a specific growth rate of $1.99 \mathrm{~h}^{-1}$ as compared to $1.91 \mathrm{~h}^{-1}$ when incubated at $35^{\circ} \mathrm{C}$ in $1 / 10$ strength TSB.

\subsection{Survival and sublethal injury of heat-stressed cells}

The D-values for the three antecedent growth conditions were determined using linear regression (Fig. 2.1). Cells grown at optimal conditions (TSB at $35^{\circ} \mathrm{C}$ ) proved to be the most heat resistant $\left(\mathrm{D}_{52}=41.15\right)$. E. sakazakii was more sensitive to thermal stress when previously grown in nutrient dilute $(1 / 10$ strength $)$ TSB $\left(D_{52}=35.56\right)$ or with full strength TSB at a lower incubation temperature of $25^{\circ} \mathrm{C}\left(\mathrm{D}_{52}=22.12\right)$ as shown in Fig. 2.1. In addition to overall survival and D-value calculations, sublethal injury was determined by comparison of the number of survivors observed on a selective medium (MacConkey agar) and a non-selective medium (TSA) (Fig. 2.2). Following $90 \mathrm{~min}$ of heat stress for those cells grown at optimum growth conditions $90 \%$ of the surviving population was sublethally injured (Fig. 2.2A). The greatest amount of sublethal injury (99.4\%) was observed for 90 min heat-stressed cells previously grown in 1/10 strength TSB at $35^{\circ} \mathrm{C}$ (Fig. 2.2B). However, sublethal injury decreased to $<90 \%$ for cells grown in TSB at $25^{\circ} \mathrm{C}$ (Fig. $2.2 \mathrm{C}$ ). 


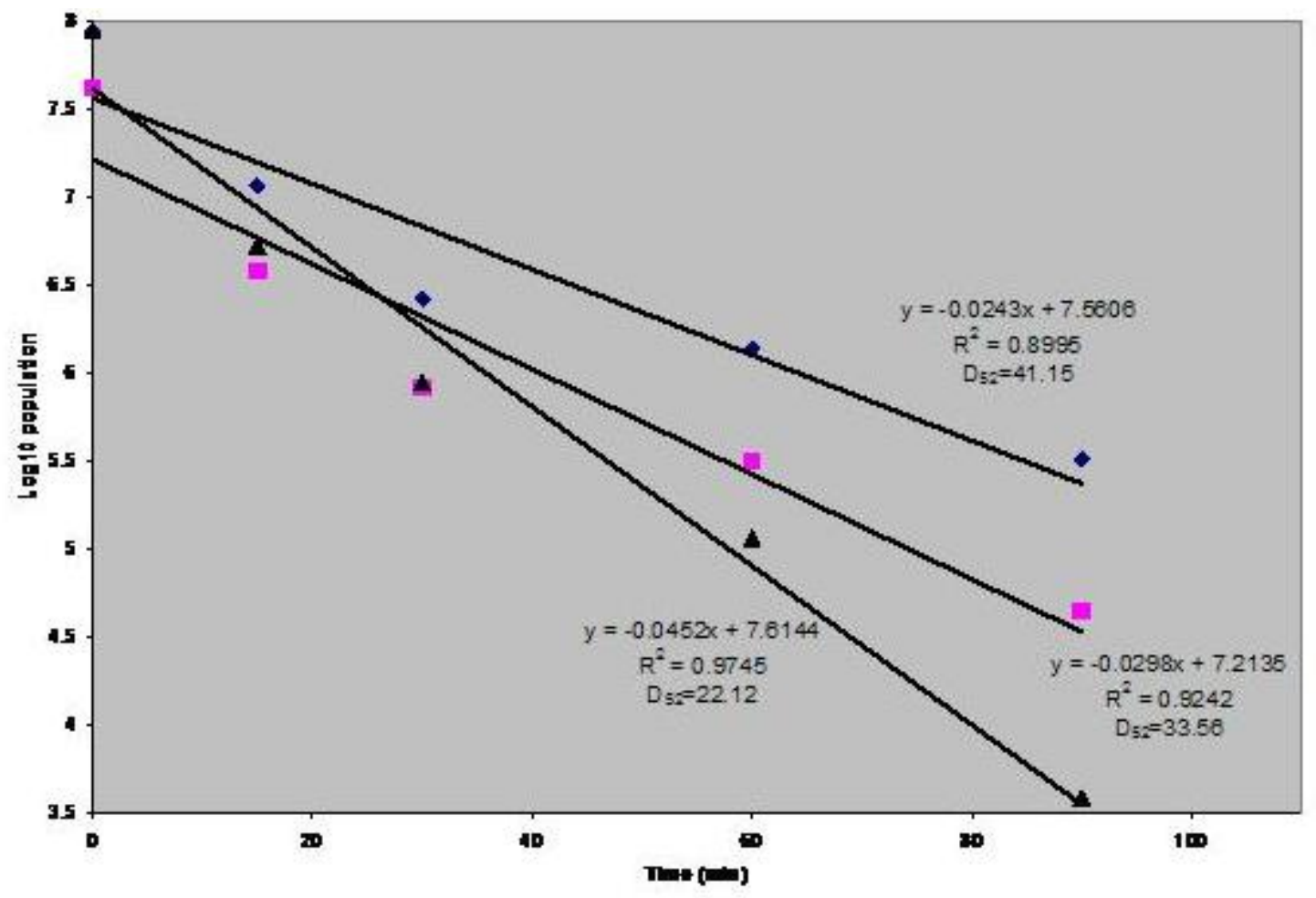

FIG 2.1. D-value determinations of thermally-stressed $\left(52^{\circ} \mathrm{C}\right) E$. sakazakii cells influenced by three antecedent growth conditions. ( $)$ growth at optimum conditions $\left(35^{\circ} \mathrm{C}\right.$, full strength TSB); (-) growth in $1 / 10$ strength TSB at $35^{\circ} \mathrm{C}$; and $(\mathbf{\Lambda})$ growth in full strength TSB at $25^{\circ} \mathrm{C}$. Cell counts were graphed using linear regression of the survival curve (triplicate TSA counts) to determine the slope. Each point represents the average of three independent experiments for all three antecedent growth conditions. 


\subsection{Effect of antecedent growth conditions on substrate utilization of heat- stressed cells as determined by the BIOLOG plate system with the use of}

AWCD and guild groupings

Concurrent with cell count determinations on a selective and nonselective media, BIOLOG GN microtiter plates were inoculuated with control and heat stressed cells. Average well color development (AWCD) was calculated by averaging the absorbance readings for all 95 substrates (Table 2.2). E. sakazakii cells incubated under optimum growth conditions showed a gradual decrease in AWCD from non-heated control cells through 90 min of heat stress, however no significant differences were observed. Cells grown at $25^{\circ} \mathrm{C}$ before exposure to heat stress showed an overall lower AWCD of substrates at all exposure times when compared to cells grown at $35^{\circ} \mathrm{C}$ and followed a similar trend in decreased values as the time of exposure increased to $90 \mathrm{~min}$. In addition, cells exposed to heat stress for 15,30 and 90 min were observed to have significantly different AWCD $(\mathrm{p}<0.05)$ than non-heated control cells. The AWCD for cells grown in 1/10 strength TSB before exposure to heat stress was higher than cells grown at $35^{\circ} \mathrm{C}$ for non-heated control and initially heat-stressed cells ( 0 time) followed by a large decrease, but only 90 min heat-stressed cells demonstrated an AWCD that was significantly different from non-heated control cells.

BIOLOG guilds are characterized according to specific chemical groups:

carbohydrates, carboxylic acids, polymers, amines, amino acids, and miscellaneous (90). Examination of average utilization of a collection of several substrates within a guild may 
provide a broader view of metabolic changes that occur to survivors of environmental stresses such as heat.

E. sakazkaii cells previously grown at $25^{\circ} \mathrm{C}$ demonstrated a significant difference between non-heated control and 90 min heat-stressed cells (2.3). In addition, non-heated and initially heat-stressed cells were observed to have a higher color formation in all guilds. Non-heated control and 90 min heat stressed cells were also compared for $E$. sakazakii grown at $35^{\circ} \mathrm{C}$ and $25^{\circ} \mathrm{C}$ (Fig. 2.4). Cells grown at $25^{\circ} \mathrm{C}$ and exposed to 90 min of heat stress showed a significant decrease in utilization of all guilds when compared to 90 min heat-stressed cells previously grown at $35^{\circ} \mathrm{C}$ (Fig. 2.4). Conversely, non-heated control cells previously grown at $25^{\circ} \mathrm{C}$ and $35^{\circ} \mathrm{C}$ demonstrated no differences.

Substrate utilization patterns for E. sakazakii grown in 1/10 TSB before exposure to heat stress reflect a nearly linear decrease as the time period of heat exposure extended to $90 \mathrm{~min}$, with a significant difference between non-heated control cells and 30 and 90 min heat-stressed cells (Fig. 2.5). Non-heated control cells had a higher utilization in all guilds compared to any other experimental group. In addition, non-heated and initially heated (0) cells were observed to have the greatest difference in the utilization of amino acids when compared to all other experimental groups (Fig. 2.5). Non-heated control cells grown in full and 1/10 strength TSB showed nearly identical guild substrate utilization patterns (Fig. 2.6). Cells grown in full TSB and exposed to stress for $90 \mathrm{~min}$ consistently showed a higher average utilization than comparable cells grown in 1/10 strength TSB in all guilds, with a significant difference in the utilization of carbohydrates, amino acids and miscellaneous guilds (Fig. 2.6). 

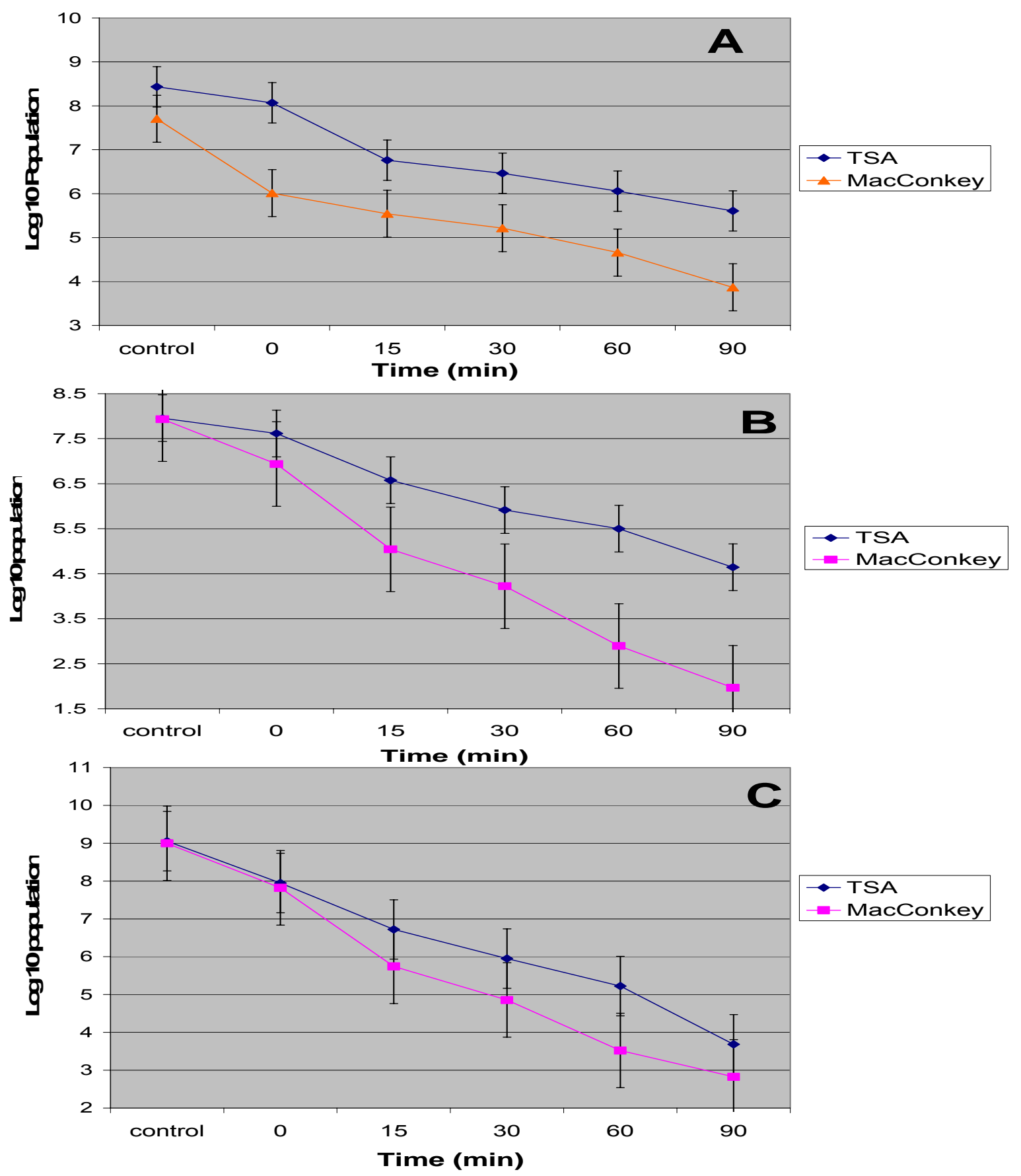

FIG 2.2. Recovery of thermally-stressed $\left(52^{\circ} \mathrm{C}\right) \mathrm{E}$. sakazakii on nonselective (TSA, $\diamond)$ and selective (MacConkey, $\square$ ) media as influenced by three different antecedent growth conditions. A) growth at optimum

conditions in full strength TSB at $35^{\circ} \mathrm{C}$; B) growth in $1 / 10$ strength TSB at $35^{\circ} \mathrm{C}$; and $\mathbf{C}$ ) growth in full strength TSB at $25^{\circ} \mathrm{C}$. Differences in colony counts between non-selective and selective media were used to calculate sublethal injury. Each point represents the average of three independent experiments. Error bars represent standard error $(\mathrm{p}<0.05)$. 
TABLE 2.2. Average well color development (AWCD) of E. sakazakii following heat stress $\left(52^{\circ} \mathrm{C}\right)$ as influenced bv different growth conditions.

\begin{tabular}{lccc}
\hline & \multicolumn{3}{c}{$\mathrm{A} \mathrm{WCD}^{2}$ for different antecedent growth conditions: } \\
\cline { 2 - 4 } Exposure time (min) & TSB @ 35 $5^{\circ} \mathrm{C}$ & TSB @ 25 $5^{\circ} \mathrm{C}$ & $1 / 10 \mathrm{TSB} @ 35^{\circ} \mathrm{C}$ \\
\hline Control $^{b}$ & 0.730 & 0.729 & 0.801 \\
0 & 0.728 & 0.715 & 0.762 \\
15 & 0.689 & $0.533^{*}$ & 0.636 \\
30 & 0.663 & $0.564^{*}$ & 0.594 \\
90 & 0.567 & $0.439 *$ & $0.507^{*}$
\end{tabular}

${ }^{a}$ Average well color development after 24 hour incubation on BIOLOG GN microplates

${ }^{\mathrm{b}}$ Cells placed into $99 \mathrm{ml}$ of $0.1 \%$ peptone at $25^{\circ} \mathrm{C}$ (no heat stress)

* t-test $(\mathrm{p}<0.05)$ shows significance when compared to control 


\subsection{Effect of antecedent growth conditions on specific substrate utilization of heat-stressed cells as determined by the BIOLOG plate system}

Specific substrate utilization differences for E. sakazakii cells exposed to 90 min of heat stress, expressed as percent differences of average AREA, are summarized in Tables 2.3 and 2.4. Ninety min heat-stressed cells, previously grown at $25^{\circ} \mathrm{C}$, utilized three substrates (L-fucose, adonitol and xylitol) significantly more $(\mathrm{p}<0.05)$ than nonheated control cells grown at both $25^{\circ} \mathrm{C}$ or $35^{\circ} \mathrm{C}$ (Table 2.3). A decrease in substrate utilization of 90 min heat-stressed cells previously grown at $25^{\circ} \mathrm{C}$ was observed for Darabitol, $\beta$-methyld-glucoside, and citric acid when compared to non-heated control cells previously grown at $25^{\circ} \mathrm{C}$ (Table 2.3). Acetic acid, $\beta$-methyld-glucoside, citric acid, and glucuronamide also demonstrated a decrease in utilization by 90 min heat-stressed cells previously grown at $25^{\circ} \mathrm{C}$ when compared to non-heated control cells grown in optimum conditions (Table 2.3).

E. sakazakii grown in $1 / 10 \mathrm{TSB}$ and exposed to 90 min of heat stress were totally incapable of utilizing D-psicose and citric acid compared to identically grown non-heated control cells (Table 2.3). Cells grown in 1/10 strength TSB and exposed to 90 min of heat stress also resulted in a decreased utilization of $\beta$-methyl-glucoside and formic acid (Table 2.3). Nearly identical impaired utilization of the same substrates (citric acid, Dpsicose, $\beta$-methyl-glucoside, and formic acid) were observed for 90 min heat-stressed cells previously grown in 1/10 strength TSB compared to non-heated control cells grown in full strength TSB. 


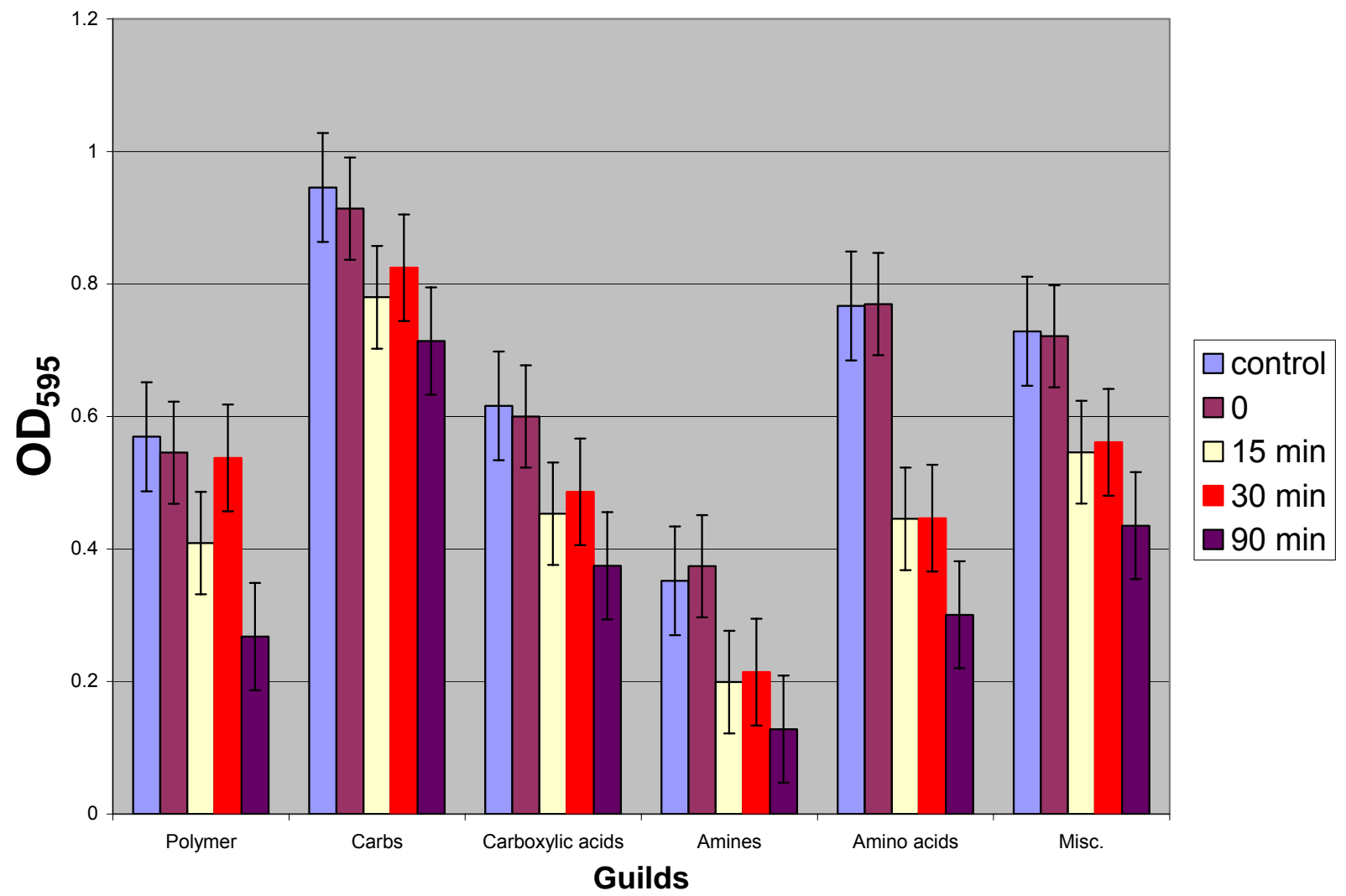

FIG. 2.3. Substrate utilization of BIOLOG guilds (expressed as average AREA) for heat stressed $\left(52^{\circ} \mathrm{C}\right) \mathrm{E}$. sakazakii previously grown in full strength TSB at $25^{\circ} \mathrm{C}$. BIOLOG GN substrates were categorized into six guilds as described by Zak et al. (1994). Color formation was read after $24 \mathrm{~h}$ incubation. Error bars represent standard error $(\mathrm{p}<0.05)$. 


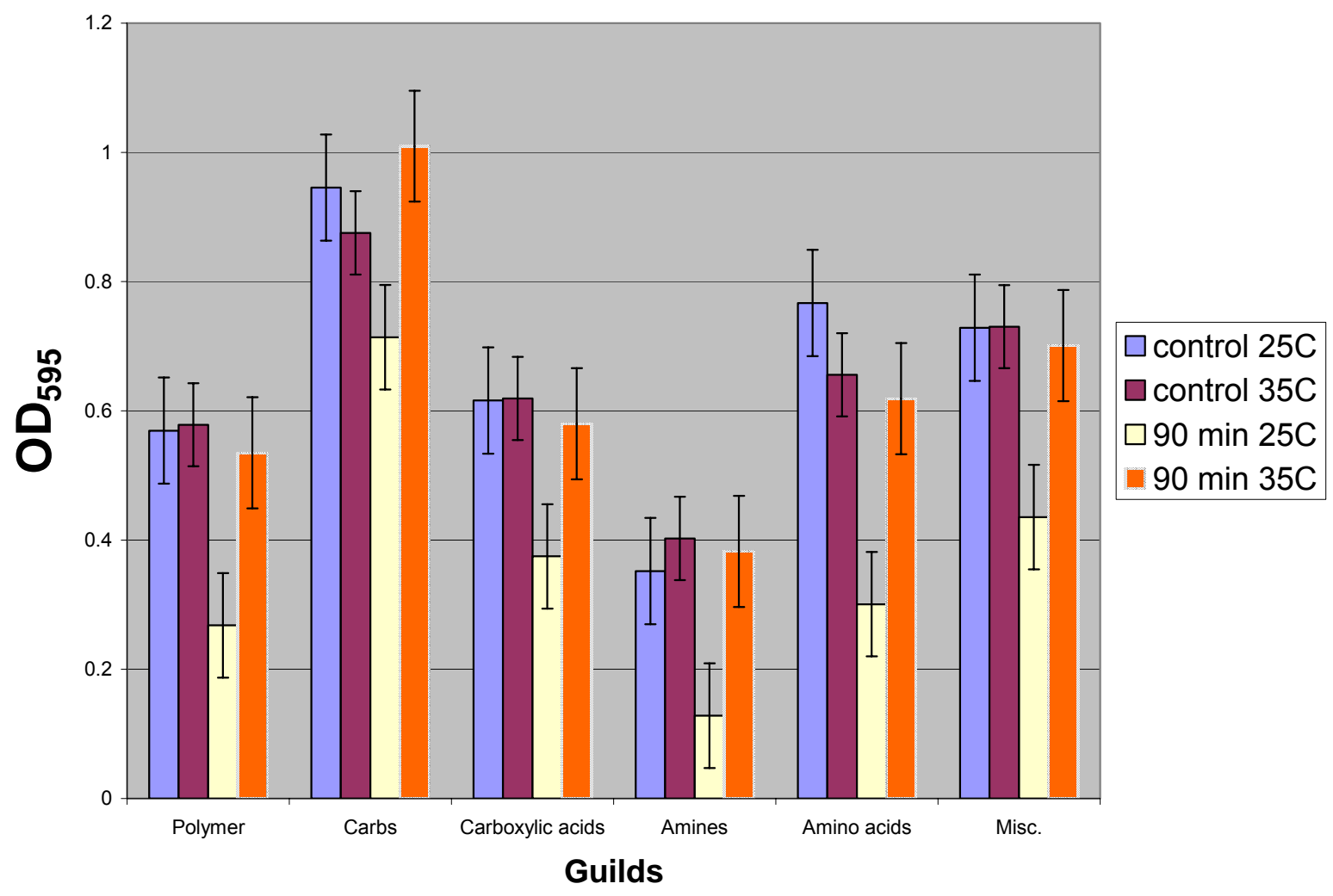

FIG. 2.4. Comparison of substrate utilization of BIOLOG guilds (expressed as average AREA) for 90 min heat-stressed $\left(52^{\circ} \mathrm{C}\right) \mathrm{E}$. sakazakii previously grown in full strength $\mathrm{TSB}$ at $35^{\circ} \mathrm{C}$ and at $25^{\circ} \mathrm{C}$.

BIOLOG GN microtiter plates were categorized into six guilds as described by Zak et al. (1994). Control cells were not exposed to heat stress. Error bars represent standard error $(\mathrm{p}<0.05)$. 


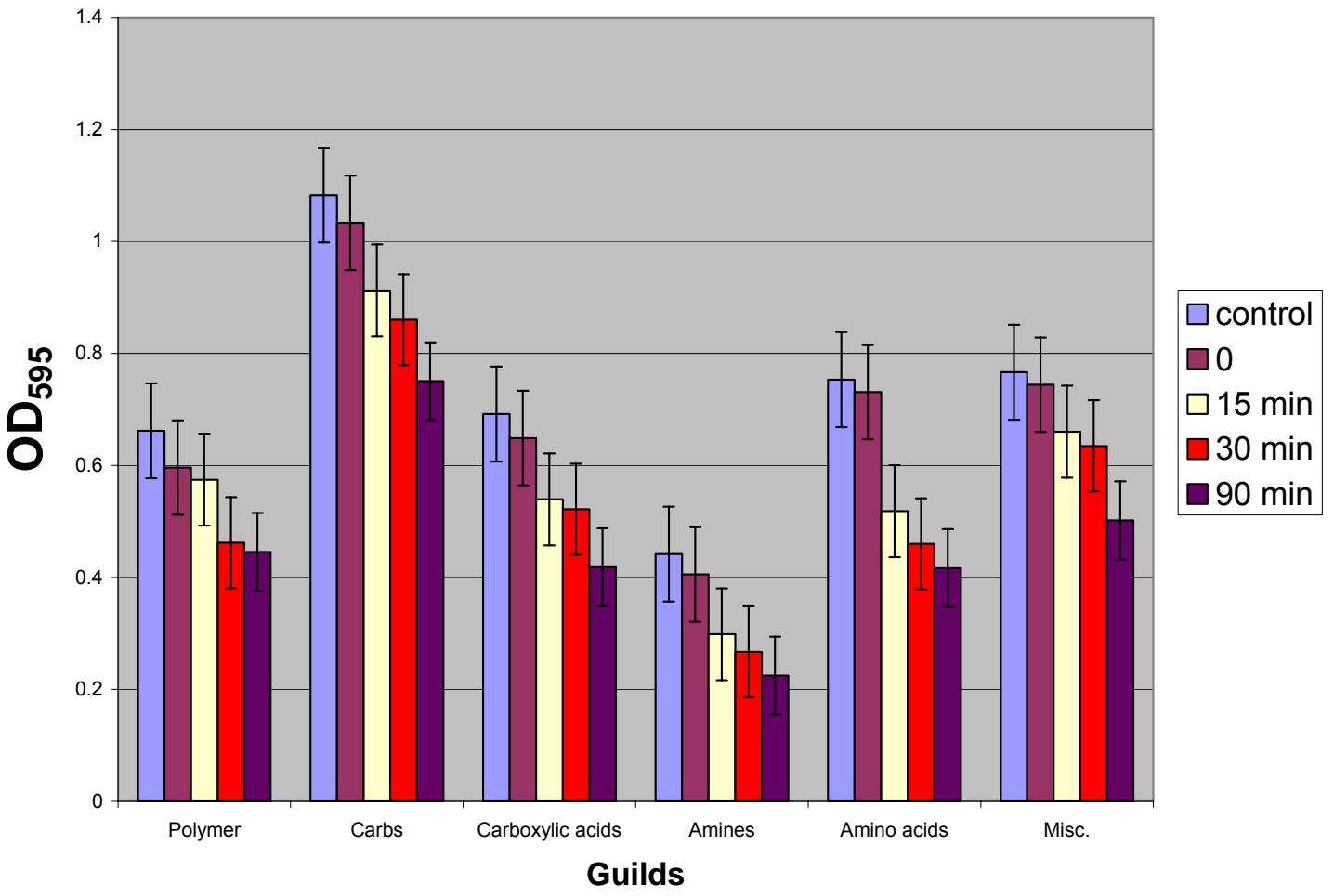

FIG. 2.5. Substrate utilization of BIOLOG guilds (expressed as average AREA) for heat stressed $\left(52^{\circ} \mathrm{C}\right) \mathrm{E}$. sakazakii previously grown in 1/10 strength $\mathbf{T S B}$ at $35^{\circ} \mathrm{C}$. BIOLOG GN substrates were categorized into six guilds as described by Zak et al. (1994). Error bars represent standard error $(\mathrm{p}<0.05)$. 


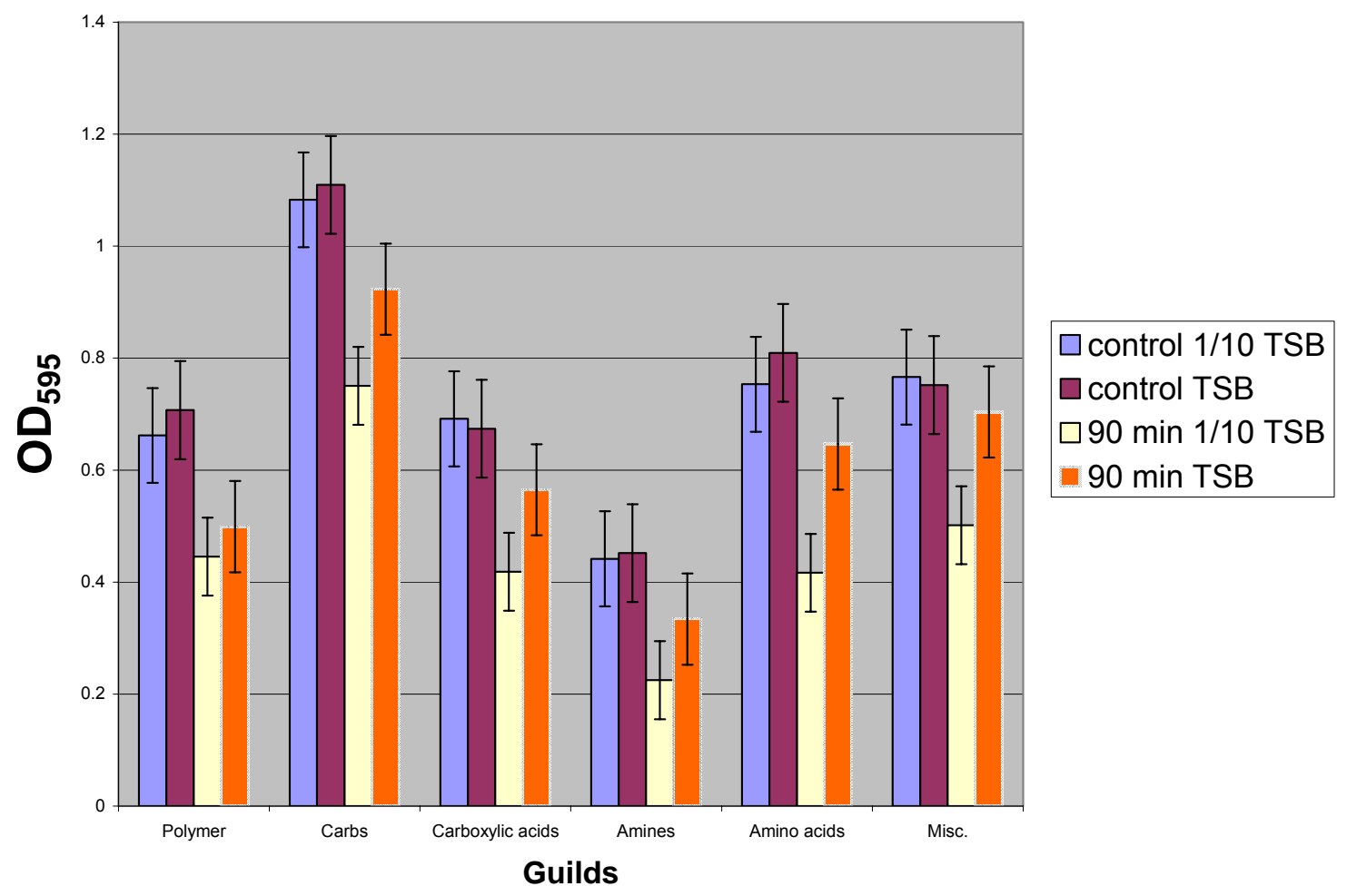

FIG. 2.6. Comparison of substrate utilization of BIOLOG guilds (expressed as average AREA) for $90 \mathrm{~min}$ heat-stressed $\left(52^{\circ} \mathrm{C}\right) \mathrm{E}$. sakazakii previously grown in full strength TSB and 1/10 strength TSB at $35^{\circ} \mathbf{C}$. BIOLOG GN microtiter plates were categorized into six guilds as described by Zak et al. (1994). Control cells were not exposed to heat stress. Error bars represent standard error $(\mathrm{p}<0.05)$. 
An increase in adonitol utilization was observed for 90 min heat-stressed cells previously grown in 1/10 strength TSB when compared to both non-heated control cells. However, an increased utilization of xylitol was only seen when 90 min heat-stressed cells were compared to non-heated control cells grown in full strength TSB (Table 2.3).

Exposure to 90 min heat-stress for cells previously grown at $25^{\circ} \mathrm{C}$ resulted in a decreased utilization of a number of substrates (D-arabitol, glucuronamide, uridine, Larabinose, citric acid, and dextrin) when compared to 90 min heat-stressed cells grown at $35^{\circ} \mathrm{C}$ (Table 2.4 ). The only substrate observed to be utilized more by heat-stressed cells previously grown at $25^{\circ} \mathrm{C}$ was adonitol.

Heat-stressed cells grown in low nutrient TSB (1/10 strength) failed to utilize citric acid and D-psicose, when compared to heat stressed cells grown in full strength TSB (Table 2.4). Uridine and $\beta$-methyl-glucoside were also used to a lesser extent $(\mathrm{p}<0.05)$ by 90 min heat-stressed cells previously grown in $1 / 10$ strength TSB when compared to heat-stressed cells grown in full strength TSB (Table 2.4). Only one substrate, L-ornithine, was utilized more by 90 min heat-stressed cells grown in 1/10 TSB. 
TABLE 2.3. Utilization of specific BIOLOG substrates by heat-stressed $\left(52^{\circ} \mathrm{C}\right.$ for $\left.90 \mathrm{~min}\right)$ Enterobacter sakazakii cultured under different antecedent growth conditions compared to substrate utilization by non-heated control cells.

\begin{tabular}{|c|c|c|c|}
\hline \multicolumn{2}{|c|}{ Comparison/growth conditions } & \multicolumn{2}{|c|}{ Substrates demonstrating $^{\mathrm{a}}$} \\
\hline Heat Stress ${ }^{b}$ & Non heat stress ${ }^{c}$ & $\begin{array}{l}\text { Increased } \\
\text { utilization }\end{array}$ & Decreased utilization \\
\hline $25^{\circ} \mathrm{C}$ & $25^{\circ} \mathrm{C}$ & $\begin{array}{c}\text { Xylitol }(100 \%) \\
\text { Adonitol }(83 \%) \\
\text { L-fucose }(81 \%)\end{array}$ & $\begin{array}{c}\text { D-arabitol (34\%) } \\
\text { b-methyl-d-glucoside }(32 \%) \\
\text { Citric acid }(30 \%)\end{array}$ \\
\hline $25^{\circ} \mathrm{C}$ & $35^{\circ} \mathrm{C}$ & $\begin{array}{c}\text { Xylitol }(95 \%) \\
\text { Adonitol }(80 \%) \\
\text { L-fucose }(75 \%)\end{array}$ & $\begin{array}{c}\text { Acetic acid }(86 \%) \\
\text { b-methyl-d-glucoside }(37 \%) \\
\text { Glucuronamide }(26 \%)\end{array}$ \\
\hline $1 / 10 \mathrm{TSB}$ & $1 / 10 \mathrm{TSB}$ & Adonitol (58\%) & $\begin{array}{c}\text { Citric acid }(100 \%) \\
\text { D-psicose }(100 \%) \\
\text { b-methyl-d-glucoside }(52 \%) \\
\text { Formic acid }(49 \%)\end{array}$ \\
\hline $1 / 10 \mathrm{TSB}$ & Full TSB & $\begin{array}{c}\text { Xylitol (69\%) } \\
\text { Adonitol (43\%) }\end{array}$ & $\begin{array}{c}\text { Citric acid }(100 \%) \\
\text { D-psicose }(100 \%) \\
\text { b-methyl-d-glucoside }(52 \%) \\
\text { Formic acid }(48 \%)\end{array}$ \\
\hline
\end{tabular}

${ }^{a}$ Those substrates indicating significant difference in utilization $(\mathrm{p}<0.05)$ as determined using the AREA formula (expressed as percent difference in parentheses)

${ }^{\mathrm{b}}$ Heat stressed for $90 \mathrm{~min}$ at $52^{\circ} \mathrm{C}$

${ }^{\mathrm{c}}$ Non-heated control cells 
TABLE 2.4. Utilization of specific BIOLOG substrates by heat-stressed $\left(52^{\circ} \mathrm{C}\right.$ for $\left.90 \mathrm{~min}\right) \mathrm{E}$. sakazakii cultured under non-optimum conditions (1/10 TSB at $35^{\circ} \mathrm{C}$ and $\mathrm{TSB}$ at $25^{\circ} \mathrm{C}$ ) compared to substrate utilization by heatstressed cells cultured under optimum conditions (TSB at $35^{\circ} \mathrm{C}$ )

\begin{tabular}{|c|c|c|c|}
\hline & & \multicolumn{2}{|c|}{ Substrates demonstrating ${ }^{a}$} \\
\hline \multicolumn{2}{|c|}{ Comparison/growth conditions } & Increased utilization & Decreased utilization \\
\hline $\mathrm{TSB}$ at $25^{\circ} \mathrm{C}$ & TSB at $35^{\circ} \mathrm{C}$ & A donitol (40\%) & $\begin{array}{l}\text { D-arabitol }(38 \%) \\
\text { Glucuronamide }(36 \%) \\
\text { Uridine }(35 \%) \\
\text { L-arabinose }(34 \%) \\
\text { Citric acid }(32 \%) \\
\text { Dextrin }(28 \%)\end{array}$ \\
\hline $1 / 10 \mathrm{TSB}$ at $35^{\circ} \mathrm{C}$ & $\mathrm{TSB}$ at $35^{\circ} \mathrm{C}$ & L-omithine $(25 \%)$ & $\begin{array}{l}\text { Citric acid }(100 \%) \\
\text { D-psicose }(100 \%) \\
\text { b-methyl-d-glucoside }(47 \%) \\
\text { Uridine }(25 \%)\end{array}$ \\
\hline
\end{tabular}

${ }^{a}$ Those substrates indicating significant difference in utilization $(p<0.05)$ as determined using the AREA formula (expressed as percent difference in parentheses) 


\section{Discussion}

Monitoring the response of a bacterium to heat stress in vitro must be taken with caution as in vitro results may not accurately reflect in situ conditions. Manipulation of antecedent growth conditions has been shown to have important physiological effects on bacterial cells, which may explain the observed changes in sensitivity towards environmental stress (61). The synthesis of heat shock proteins (HSP) can be induced by exposure to sublethal environmental stresses (starvation, heat shock, ethanol, and acid), and these proteins are known to aid in the microbial cross protection system (85). It has been observed that $E$. coli cells in the exponential phase needed only five min to reach an equivalent decrease in viable cells that stationary phase E. coli cells demonstrated in 60 min when exposed to $52^{\circ} \mathrm{C}(72)$. This observed cross-protection of stationary phase cells exhibiting decreased sensitivity towards heat stress is the result of an induction of HSP aiding in the repair of environmentally stressed cells. Few researchers have examined the effect that low temperature has on a bacterium's sensitivity towards heat stress. Zhang and Griffiths (92) reported that starved E. coli O157:H7 cells grown at low temperature showed a significant increase in thermotolerance. However, it was also shown that nonstarved cells grown at low temperature expressed a decreased thermotolerance at $52^{\circ} \mathrm{C}$ (92). These results may suggest that while pre-growth at low temperature decreases a bacterium's sensitivity towards heat stress, starvation induced cells were able to counteract this physiological effect.

Growth rate and survival curves. In the present study, E. sakazakii grown under less than ideal conditions $\left(1 / 10 \mathrm{TSB}\right.$ at $35^{\circ} \mathrm{C}$ or $\mathrm{TSB}$ at $\left.25^{\circ} \mathrm{C}\right)$ were more sensitive to heat stress than cells grown under optimal conditions in TSB at $35^{\circ} \mathrm{C}$ (Table $2.5-$ see 
D-values). Nevertheless, we observed lower specific growth rates for the low nutrient and low temperature cultured cells (Table 2.5), contrary to the findings of Ihssen and Egli (34) which suggested that the global stress regulatory protein RpoS is inversely correlated with specific growth rate, therefore potentially causing a decreased sensitivity towards stress with a slower specific growth rate. However, our specific growth rates for cells under all three antecedent growth conditions were not as low as growth rates observed by Ihssen and Egli (34).

The D-value for cells grown under optimal conditions $\left(35^{\circ} \mathrm{C}\right.$, full strength TSB) was higher than in cells grown at low temperature $\left(25^{\circ} \mathrm{C}\right)$ or in a nutrient dilute medium (1/10 TSB), thus suggesting a decrease in thermotolerance of cells grown in nonoptimum conditions (Fig. 2.1). These data are contradictory to the cross-protection hypothesis, which proposes that exposure to sublethal environmental stressors induces the production of stress proteins in bacteria. Zhang and Griffiths (92) were able to successfully demonstrate this cross-protection in E. coli O157:H7, which when exposed to starvation for $3 \mathrm{~h}$ resulted in an increase in D-values. One reason for our contradictory results may be that cells cultured under all three antecedent growth conditions were exposed to heat stress after $24 \mathrm{~h}$ of growth, which would have allowed the bacterium to reach the stationary phase. If, instead, cells had been exposed to heat stress during the log phase of growth, different results may have been observed.

Cells grown in TSB at $25^{\circ} \mathrm{C}$ were observed to have the lowest amount of sublethal injury $(<90 \%)$ as well as the lowest thermotolerance, indicating that few heatinjured cells were able to survive 90 min of stress (Fig. 2.2 and Table 2.5). Cells grown in a nutrient dilute medium (1/10 TSB) showed the largest amount of sublethal injury 
(99.4\%) and demonstrated more thermotolerance than cells grown in TSB at $25^{\circ} \mathrm{C}$ (Fig.

2.2 and Table 2.5). The observed increase in thermotolerance and sublethal injury in cells grown in 1/10 strength TSB may decrease the effectiveness of direct use of selective media, such as MacConkey agar, for the detection of injured cells.

BIOLOG identification system. The metabolic burden placed on environmentally stressed cells occurs as a result of the increased production of stress proteins to counteract a cell's sensitivity towards stress. The use of the BIOLOG identification system was originally evaluated by Miller and Rhoden (55) as a method to correctly identify clinical and environmental isolates. The BIOLOG microtiter plate evaluates the ability of an organism to oxidize a panel of 95 different carbon sources by the exchange of electrons produced during utilization of a substrate and subsequent respiration, leading to the reduction of a tetrazolium-based color change (26). Numerous studies have demonstrated the usefulness of BIOLOG microtiter plates as a means to identify the potential metabolic diversity of bacterial communities (63). The large diversity in carbon substrates found in BIOLOG microtiter plates suggests that this system could be utilized to determine the physiological change in a bacterium following stress. Information on the ability of BIOLOG microplate system to distinguish between repressed and induced metabolic functions, however, is limited. Ihssen and Egli (35) successfully used the BIOLOG system to identify numerous catabolic changes in E. coli due to carbon-limited growth conditions. The observed ability of the BIOLOG system in identifying metabolic differences amongst $E$. coli cells presumably indicates that it could also be used to determine physiological differences in bacteria as related to different antecedent growth conditions. 
TABLE 2.5. Average specific growth rate, D-value, and sublethal injury of $E$. sakazakii as influenced bv different growth conditions.

\begin{tabular}{llllr}
\hline \multicolumn{2}{c}{ Growth Conditions } & & & \\
\cline { 1 - 2 } Medium & Temperature & Specific Growth Rate & D-value & Sublethal Injury \\
\hline TSB $^{\mathrm{c}}$ & $35^{\circ} \mathrm{C}$ & $2.30 \mathrm{~h}^{-1}$ & 41.15 & $90 \%$ \\
TSB & $25^{\circ} \mathrm{C}$ & $1.99 \mathrm{~h}^{-1}$ & 22.12 & $<90 \%$ \\
$1 / 10 \mathrm{TSB}$ & $35^{\circ} \mathrm{C}$ & $1.91 \mathrm{~h}^{-1}$ & 33.56 & $>99 \%$ \\
\hline
\end{tabular}

${ }^{\text {a }}$ Specific growth rate was calculated as $1 / \mathrm{G}$ during the log phase of growth

${ }^{b}$ Differences in viable colony counts on selective media (MacConkey agar) from colony counts on non-selective media (TSA) following $90 \mathrm{~min}$ of heat stress at $52^{\circ} \mathrm{C}$ were used to calculate sublethal injury

${ }^{c}$ Optimum growth conditions used for comparison of other antecedent growth conditions 
Average well color development. AWCD was higher for E. sakazakii cells grown in 1/10 TSB for control and 0 time cells compared to cells grown under optimum conditions (Table 2.2). Cells grown in a nutrient depleted environment could potentially result in a higher expressed affinity for a wide variety of carbon sources. Therefore, when inoculated into BIOLOG microplates, these cells were already expressing a variety of catabolic genes, whereas cells grown under optimum conditions may have been expressing a limited number of catabolic genes, thus causing a lower AWCD. However, after 15 to 90 min of stress cells grown in 1/10 strength TSB expressed a decrease in AWCD (Table 2.2), possibly due to increased sublethal injury (Table 2.5). Recent research has suggested that a decrease in specific growth rate causes cellular metabolism to become more flexible, allowing for the utilization of multiple substrates (35). In a similar fashion, we observed that cells grown in 1/10 TSB had a lower specific growth rate than cells grown in full strength TSB (Table 2.5).

BIOLOG guilds. Of the two less than optimal antecedent growth conditions examined, nutrient depletion (1/10 TSB) had the most effect on utilization of substrates within guilds. Substrate utilization patterns in E. sakazakii cells grown in 1/10 strength TSB before exposure to heat stress reflect a nearly linear decrease in utilization as the time period of heat exposure extended to $90 \mathrm{~min}$ (Fig. 2.5). A correlation in the exposure to heat stress to a decrease in the utilization of each guild was observed, suggesting a decrease in metabolic capabilities for such cells. This observation may be related to the substantial sublethal injury levels observed for these nutrient-limited cultured cells (Table 2.5). In addition, 90 min heat-stressed cells showed a decreased utilization of all guilds $(\mathrm{p}<0.05)$ when compared to non-heated control cells (Fig. 2.5). In addition, 90 min heat- 
stressed cells were observed to have the lowest utilization in the amine guild. The amine guild consists mostly of polyamines, which have been implicated in many biological processes, such as stabilizing membranes and stimulating enzyme activity (79).

However, it has also been reported that an excess amount of polyamines may actually be damaging to bacterial cells by inhibiting growth and protein synthesis (29). Heat injured cells may show an increase in the production of proteins in response to stress, resulting in an increased synthesis of proteins. Therefore, the observed reduction in amine transport for heat injured cells may be a mechanism to avoid a harmful excess concentration of polyamines.

Previous observations showed that non-heated control cells grown in 1/10 strength TSB had a higher AWCD than non-heated control cells grown in full strength TSB (Table 2.2). This high AWCD coincided with higher guild substrate utilization patterns observed for non-heated control cells grown in full and 1/10 strength TSB (Fig. 2.6). However, cells grown in full TSB and exposed to 90 min of heat stress consistently showed a higher average utilization of substrates for all guilds when compared to 90 min heat-stressed cells grown in 1/10 TSB (Fig. 2.6). The large amount of sublethal injury observed in 90 min heat-stressed cells grown in 1/10 strength TSB may account for this decreased utilization in guilds.

Characterizing physiological changes in E. sakazakii previously grown at $25^{\circ} \mathrm{C}$ with the use of guilds demonstrated similar results to cells previously grown in 1/10 TSB in that 90 min heat-stressed cells utilized guild substrates significantly lower (Fig. 2.4). The increased amount of death related to the decreased thermotolerance of E. sakazakii 
cells previously grown at $25^{\circ} \mathrm{C}$ is a possible explanation to the lower catabolic activity of 90 min heat-stressed cells.

Specific substrate utilization. E. sakazakii cultured under all three antecedent growth conditions demonstrated a high similarity $(\sim 90 \%)$ in utilization of specific substrates found in the BIOLOG microtiter plate. However, notable exceptions for a limited number of substrates were observed for heat-stressed E. sakazakii suggesting that the BIOLOG system may be useful for identification of the physiological response of those cells incurring environmental stress (Table 2.3). For example, cells previously grown at $25^{\circ} \mathrm{C}$ and exposed to heat stress for 90 min showed a decreased utilization of D-arabitol, $\beta$-methyld-glucoside, and citric acid when compared to non-heated control cells previously grown at $25^{\circ} \mathrm{C}$ (Table 2.3). Citric acid is an important intermediate in the TCA cycle. This catabolic pathway generates energy, reducing power, and precursors of biosynthesis of sugars, amino acids, and nucleotides (13). The observation that Darabitol was utilized more by non-heated control cells grown at $25^{\circ} \mathrm{C}$ than 90 min heatstressed cells as opposed to increased use of adonitol and xylitol by 90 min heat-stressed cells previously grown at $25^{\circ} \mathrm{C}$ (Table 2.3 ) appears contradictory as all three substrates are found in the same pathway. Adonitol, xylitol, and D-arabitol are three of four pentitols which are catabolized in the pentose-phosphate pathway. Increased utilization of L-fucose by $90 \mathrm{~min}$ heat-stressed cells grown at a low temperature $\left(25^{\circ} \mathrm{C}\right)$ was also observed (Table 2.3). Reasons for this increase in utilization are undetermined.

A decrease in the utilization of acetic acid, $\beta$-methyld-glucoside, citric acid, and glucuronamide was demonstrated by E. sakazakii cells grown at $25^{\circ} \mathrm{C}$ and, exposed to 90 min of heat stress when compared to non-heated control cells grown at $35^{\circ} \mathrm{C}$ (Table 2.3 ). 
E. sakazakii cells grown at a low temperature $\left(25^{\circ} \mathrm{C}\right)$ also were observed to have a lower specific growth rate than cells grown in optimum conditions (Table 2.5). Therefore, there is a possibility that cells grown at optimum conditions were expressing acetate affinity enzymes at a high rate due to the high rate of utilization of this substrate.

E. sakazakii cells grown in 1/10 TSB and exposed to 90 min of heat were completely incapable of utilizing D-psicose and citric acid (Table 2.3). A previous decrease in the utilization of citric acid was seen in low temperature $\left(25^{\circ} \mathrm{C}\right) 90$ min heatstressed cells but not to the extent seen here. Citric acid is metabolized as an important intermediate of the TCA cycle, while D-psicose is a low energy sugar molecule containing a phosphate (41). D-psicose may also be used as a small carbon source with no known uses in other pathways. Further research is needed to determine why these two catabolic pathways are turned off in nutrient deprived 90 min heat stressed cells previously grown in $1 / 10$ strength TSB. Cells grown in $1 / 10$ strength TSB and exposed to 90 min of heat stress also showed a decrease in utilization of $\beta$-methyl-glucoside and formic acid when compared to non-heated control cells previously grown in 1/10 strength TSB (Table 2.3). $\beta$-methyl-glucoside is found mostly in plant material and can be used as the sole carbon source for many enteric bacteria. Most enteric bacteria cleave $\beta$ glucosides to produce glucose-6-P which can then be assimilated into glycolysis (23). An increased utilization of xylitol and adonitol was observed in 90 min heatstressed cells previously grown in 1/10 strength TSB when compared to non-heated control cells previously grown in TSB (Table 2.3). Previous observations by $90 \mathrm{~min}$ heat-stressed cells have demonstrated that an observed increased utilization in xylitol is 
related with a similar increased utilization of adonitol, when compared to non-heated control cells.

In order to determine if the observed changes in specific substrate utilization of heat-stressed cells could also be influenced by antecedent growth conditions, 90 min heat stressed cells grown under non-optimum conditions were compared to 90 min heatstressed cells grown under optimum conditions. E. sakazakii heat-stressed for 90 min previously grown at $25^{\circ} \mathrm{C}$ showed a decreased utilization of a number of substrates (Darabitol, glucuronamide, uridine, L-arabinose, citric acid, and dextrin) when compared to 90 min heat-stressed cells grown at $35^{\circ} \mathrm{C}$ (Table 2.3). Decreased use of complex substrates such as glucuronamide and uridine may be related to the increased sensitivity of these cells towards heat stress as reflected by their low $\mathrm{D}$-value $\left(\mathrm{D}_{52}=22.98\right)$. On the other hand, D-arabitol and L-arabinose can be utilized in the pentose-phosphate pathway. Decreased utilization of citric acid was seen previously when comparing 90 min heatstressed cells grown at $25^{\circ} \mathrm{C}$ to non-heated control cells grown at both $35^{\circ} \mathrm{C}$ and $25^{\circ} \mathrm{C}$ (Table 2.4). However, adonitol was observed to show an increase in substrate utilization by 90 min heat-stressed cells previously grown at $25^{\circ} \mathrm{C}$ when compared to 90 min heatstressed cells previously grown at $35^{\circ} \mathrm{C}$ was (Table 2.4 ). These observations suggest that physiological changes due to exposure to heat stress may be influenced by culturing $E$. sakazakii at $25^{\circ} \mathrm{C}$ instead of at $35^{\circ} \mathrm{C}$.

Heat-stressed cells grown in 1/10 TSB demonstrated a complete shut down in the utilization of citric acid and D-psicose when compared to 90 min heat-stressed cells grown under optimum conditions (Table 2.4). This observation was previously seen when comparing 90 min heat-stressed cells grown in a nutrient depleted medium $(1 / 10$ 
TSB) to non-heated control cells (TSB and 1/10 TSB) (Table 2.3). A reason for shutdown of the metabolism of citric acid is undetermined at this point. Uridine was also observed to be utilized significantly less by cells grown under nutrient deplete conditions when compared to heat-stressed cells grown in full strength TSB. Uridine is catabolized in ribose phosphate degradation, leading to D-ribose-5-phosphate which can then be sent to the pentose phosphate pathway (13). The single substrate observed to have an increased utilization by heat-stressed cells grown in 1/10 TSB was L-ornithine (Table 2.4). L-ornithine is degraded into succinate through multiple metabolic reactions. Succinate then moves into the TCA cycle where it is an important intermediate. In previous experiments (see Chapter 1) BIOLOG microplates were used to demonstrate metabolic changes in E. sakazakii following exposure to heat stress. Here, we document that BIOLOG microplates can also be used to show metabolic changes due to heat stress and as a result of the influence of non-optimum antecedent growth conditions (TSB at $25^{\circ} \mathrm{C}$ and $1 / 10 \mathrm{TSB}$ at $35^{\circ} \mathrm{C}$ ). These results show that notable differences in substrate utilization by heat-stressed E. sakazakii grown under all three antecedent conditions occurred. Further studies are necessary to determine if the observed differences in metabolic patterns may be used to increase the effectiveness of isolating heat-stressed E. sakazakii from the environment.

In all experiments examined in this study, 90 min heat-stressed cells grown under non-optimum conditions (TSB at $25^{\circ} \mathrm{C}$ and $1 / 10$ strength $\mathrm{TSB}$ at $35^{\circ} \mathrm{C}$ ) resulted in enhanced utilization of both adonitol and xylitol (Table 2.3; Fig. 2.8 and 2.9 in Appendix). Only a few enteric bacteria have been identified that can naturally degrade xylitol and these include Morganella morganii, Providencia stuartii, and Serratia 
marcescens (15). It has previously been shown that adonitol and D-arabitol are degraded in two separate inducible pathways in E. coli (74). Therefore, while adonitol activity is unaffected by the increase in xylitol activity, it may have a negative effect on D-arabitol activity as the xylitol pathway becomes established by borrowing the transport system for D-arabitol (56). The observed increased xylitol and adonitol activity may be beneficial to stressed bacteria since metabolism of these substrates is important for several essential anabolic pathways (Fig. 2.7). The process of adding a phosphate to xylitol may be particularly important since xylulose-5-phosphate is required for the synthesis of many of the polysaccharides of the LPS (50). An increased synthesis of LPS could potentially aid in the survival of stressed E. sakazakii cells by creating a protective outer layer and increasing biofilm formation for adhesion to surfaces. Lohrke et al. (50) also reported that adonitol and xylitol catabolism creates precursors for the biosynthesis of purines and pyrimidines, potentially aiding stressed cells with the repair of damaged nucleotides (Fig. 2.7). Future studies are needed to determine if increased synthesis of substrates for construction of the LPS or of purines and pyrimidines for E. sakazakii aid in the response to heat stress. 


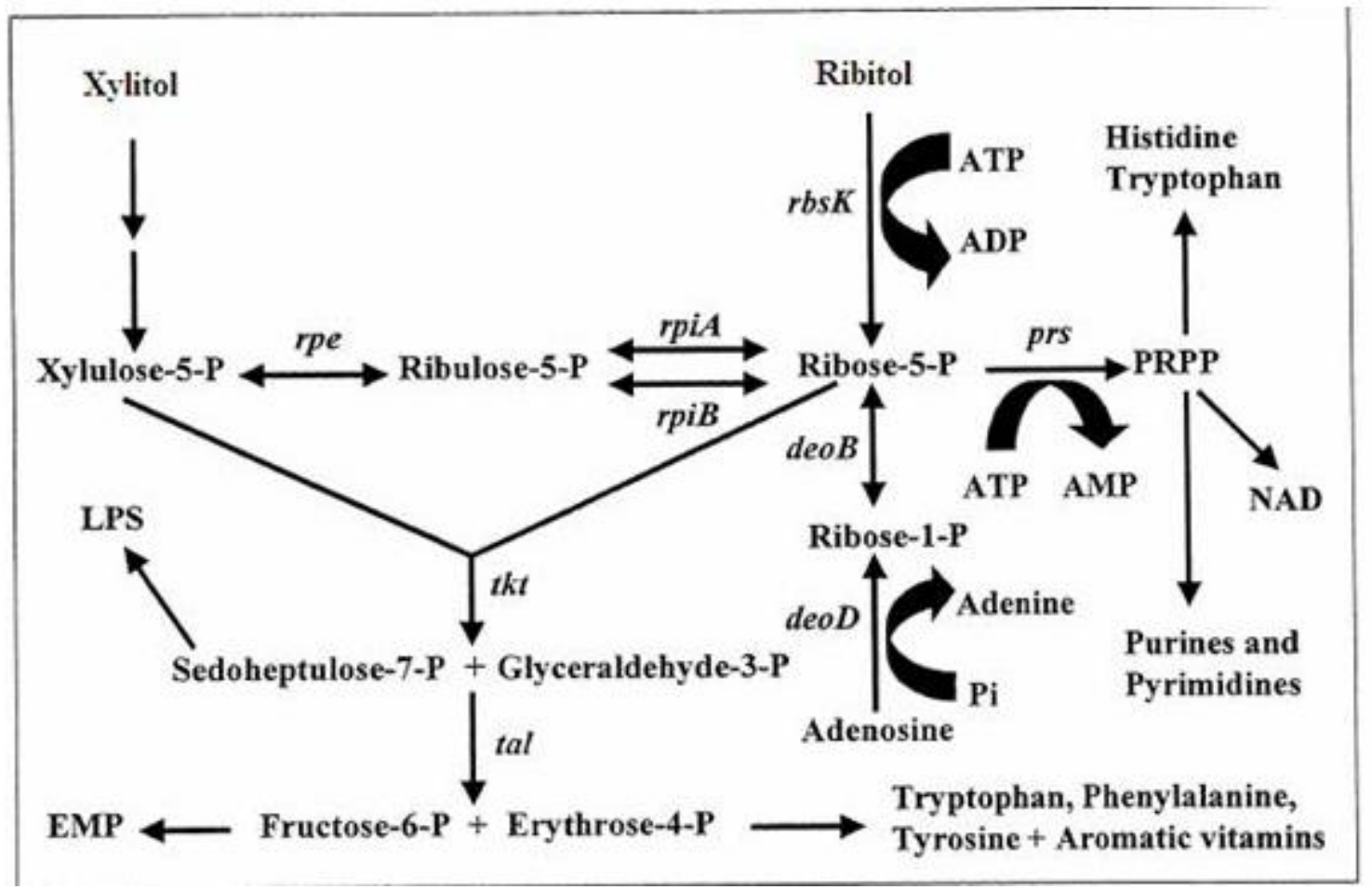

FIG 2.7. Pentose-phosphate metabolism in enteric bacteria. Metabolism of pentitols in Enterobacter cloacae with emphasis placed on the anabolic portion of the pathway. PRPP = 5-phosphoribosyl 1-pyrophosphate; EMP = Embdem-Meyerhoff Pathway; LPS = lipopolysaccharide; NAD = nicotinamide adenine dinucleotide; deoB = phosphodeoxyribomutase; deoD = purine nucleoside phosphorylase; prs = phosphoribosyl diphosphate synthetase; rbsK = ribokinase; rpe = ribose phosphate epimerase; rpiA = ribose phosphate isomerase $\mathrm{A}$; rpiB = ribose phosphate isomerase $\mathrm{B}$; tal = transaldolase; $\mathrm{tkt}=$ transketolase. (Lohrke et al., 2002) 


\section{Summary}

The influence of three different antecedent growth conditions on the physiological response of heat-stressed E. sakzakii was monitored using conventional plate count methodology and the BIOLOG microplate system. Our findings suggest that the BIOLOG system may be of value as a supplement to traditional viability measurements for assaying physiological adaptations of environmentally stressed bacteria. Specific observations include:

- Antecedent growth under non-optimum conditions resulted in an increased sensitivity to heat stress as reflected by decreased D-values and specific growth rate as compared to unheated cells. Cells previously grown in TSB at $25^{\circ} \mathrm{C}$ were the most sensitive to heat stress (based on D-values) with a corresponding lower level of sublethal injury, whereas cells previously grown in $1 / 10$ strength $\mathrm{TSB}$ at $35^{\circ} \mathrm{C}$ were relatively less sensitive to heat stress but incurred a higher level of sublethal injury.

- Generalized application of the BIOLOG system using AWCD and guild groups suggested a correlation with increased exposure to heat stress and decreased catabolic activity. Notable differences in specific substrate utilization were observed in heat-stressed E. sakazakii cultured under all three antecedent growth conditions. Cells previously grown under non-optimum conditions demonstrated an increased utilization of adonitol and xylitol. The adjustments in utilization of specific substrates suggest that the BIOLOG system may be useful for determination of the physiological response of $E$. sakazakii to heat stress. 
6. Appendix 

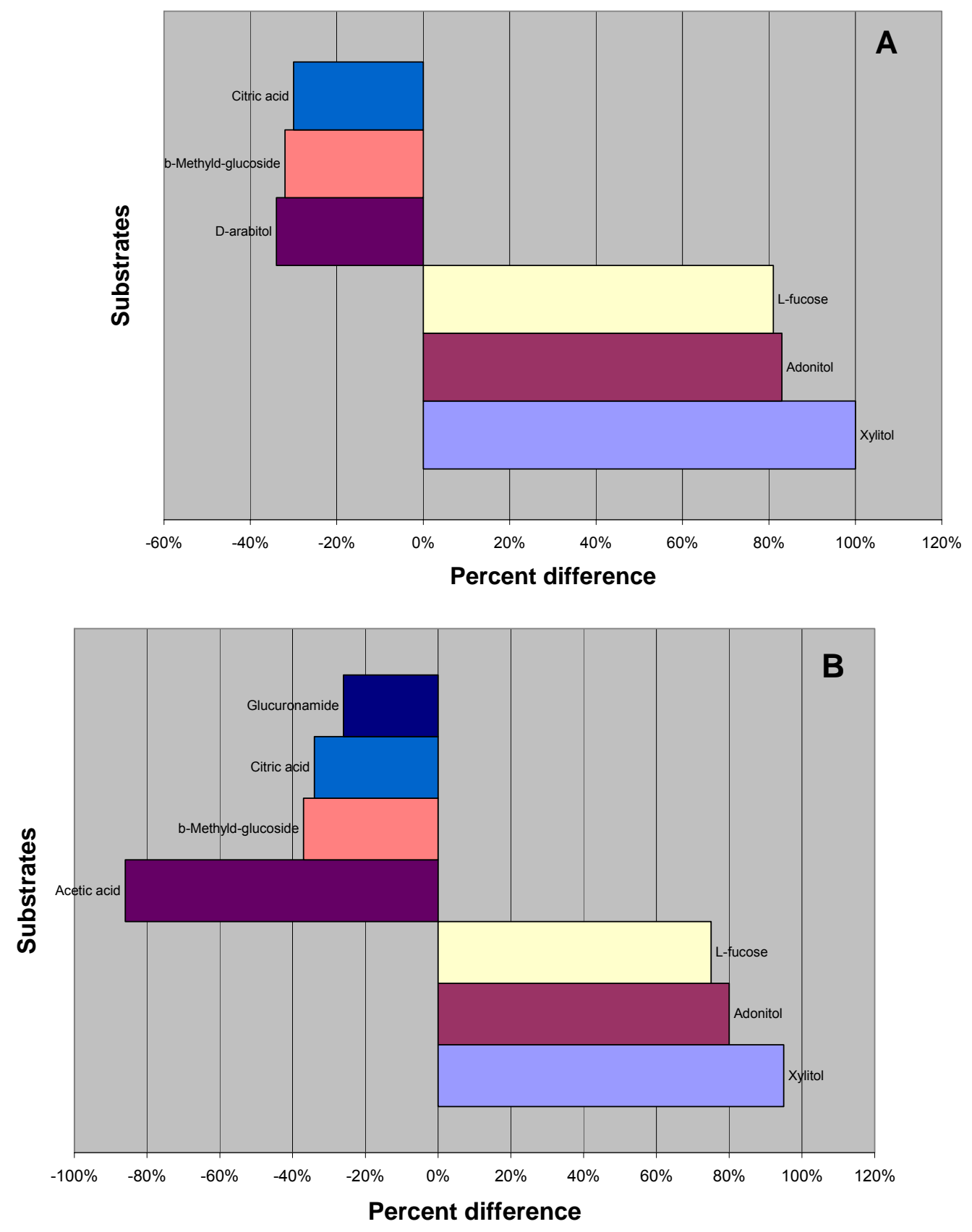

FIG 2.8. Differences in substrate utilization of $90 \mathrm{~min}$ heat-stressed $E$. sakazakii previously grown at $25^{\circ} \mathrm{C}$ in TSB compared to substrate utilization of non-heated control cells previously grown at (A) $25^{\circ} \mathrm{C}$ and (B) $35^{\circ}$ C. Substrate utilization was determined using the AREA formula, and graphed as percent difference in utilization. 

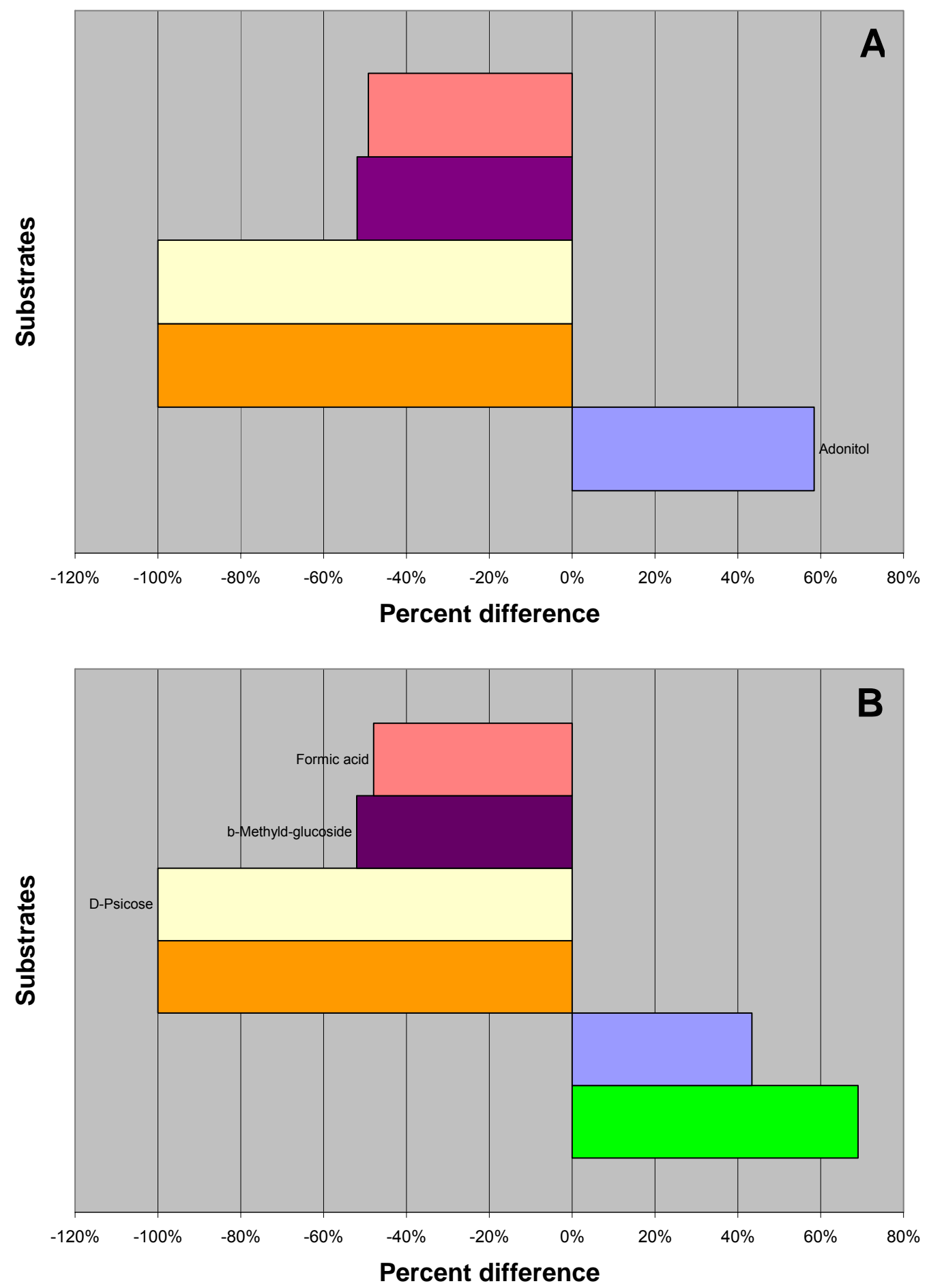

FIG. 2.9. Differences in substrate utilization of 90 min heat-stressed $E$. sakazakii previously grown in 1/10 strength TSB compared to substrate utilization of non-heated control cells grown in (A) 1/10 strength TSB at $35^{\circ} \mathrm{C}$ and (B) full strength TSB at $35^{\circ} \mathrm{C}$. Substrate utilization was determined using the AREA, and graphed as percent difference in utilization. 


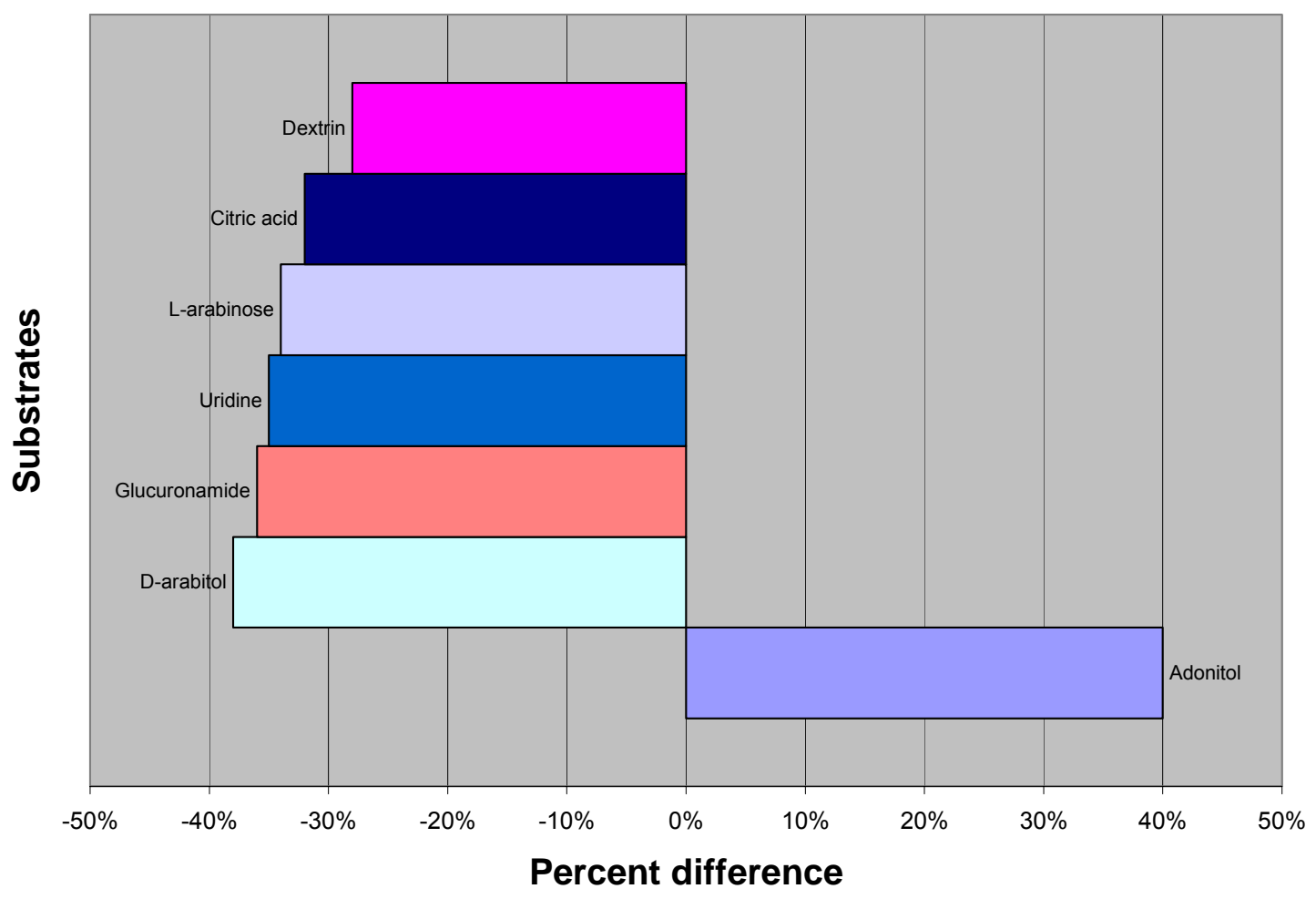

FIG. 2.10. Differences in substrate utilization of 90-min heat stressed $\left(52^{\circ} \mathrm{C}\right) \mathrm{E}$. sakazakii previously grown in full strength $\mathrm{TSB}$ at $25^{\circ} \mathrm{C}$ compared to substrate utilization of $90 \mathrm{~min}$ heat-stressed cells previously grown in full strength $\mathbf{T S B}$ at $35^{\circ} \mathrm{C}$. Substrate utilization was determined using the AREA formula, and graphed as percent difference in utilization. 


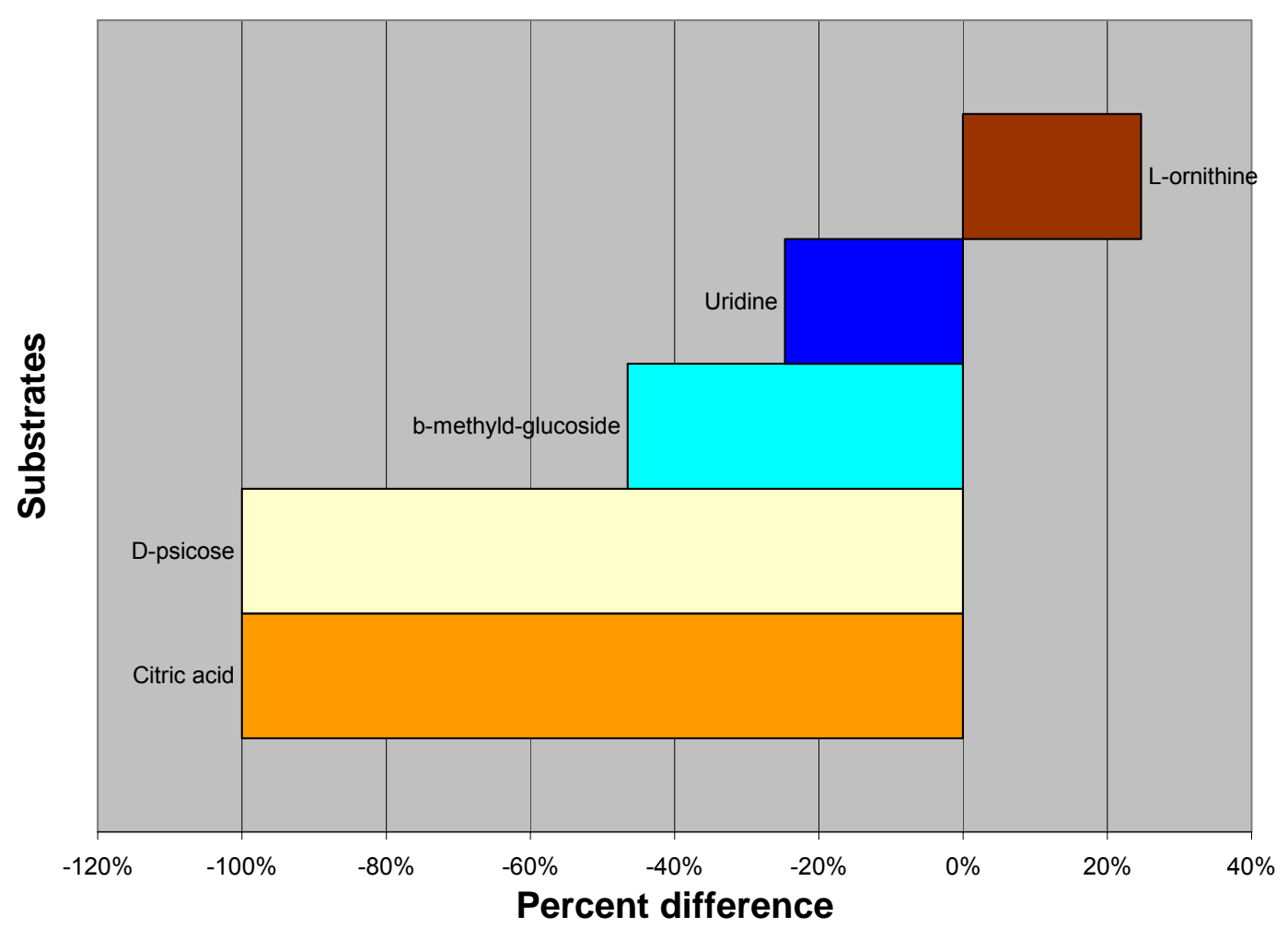

FIG. 2.11. Differences in substrate utilization of 90-min heat stressed $\left(52^{\circ} \mathrm{C}\right)$ E. sakazakii previously grown in $1 / 10$ strength $\mathrm{TSB}$ at $35^{\circ} \mathrm{C}$ compared to substrate utilization of $90 \mathrm{~min}$ heat-stressed cells previously grown in full strength $\mathbf{T S B}$ at $35^{\circ} \mathrm{C}$. Substrate utilization was determined using the AREA formula, and graphed as percent difference in utilization. 
Chapter 3:

Application of the BIOLOG microplate system to assay physiological changes in desiccated E. sakazakii cells exposed to heat stress 


\section{Introduction}

E. sakazakii has been regarded as an opportunistic pathogen and has been linked to life threatening neonatal meningitis, septicemia, and necrotizing enterocolitis outbreaks (6). E. sakazakii has been detected in a wide variety of foods such as cheese, meat vegetables, grains, and milk. However, the implicated source of infection is most commonly associated with dried infant formula (66). E. sakazakii has been isolated from dried infant formula in numerous studies $(7,36,47,58,62)$ with detection ranging from $2.4 \%$ to $14.2 \%$ of samples tested. Since dried infant formula has an $\mathrm{a}_{\mathrm{w}}$ of 0.2 the ability of E. sakazakii to survive may depend on its ability to resist desiccation. In a recent study, Edelson-Mammel and Buchanan (16) reported that desiccated E. sakazakii cells could survive in dried infant formula for up to 18 months. This observation supported previous speculations that dried infant formula could potentially be a source of $E$. sakazakii infections.

E. sakazakii is also more resistant to air drying than other Enterobacteriaceae such as Escherichia coli and Salmonella sp., presumably the result of increased accumulations of the osmoprotectant trehalose (11). Consequences of drying are essentially different from those resulting from osmotic stress, as cells must rely on previous accumulation of specific molecules to serve some structural or protective role before becoming metabolically inactive (66). The intracellular accumulation of a nonreducing saccharide, such as trehalose and sucrose, helps to increase survival of dessicated cells by protecting liposomes and biological membranes (8). During the desiccation process, water is removed from the lipid bilayers and headgroups are brought closer together. This causes the dry bilayer to form into a gel phase at room temperature 
which potentially leads to membrane leakage and cell death. The addition of a disaccharide before dessication helps to increase survival by replacing the water between the lipid headgroups, thus minimizing membrane leakage after rehydration (46).

Cellular responses to desiccation have been examined with the use of DNA microarrays, permitting comparison of gene expression in non-desiccated and desiccated cells (66). Up-regulation of several glycolytic and fermentative enzymes combined with increased synthesis of molecular chaperones were observed. Of the chaperones identified, a heat shock protein was observed only in desiccated cells, suggesting that desiccated cells may be more heat resistant than non-desiccated cells (66). It has also been suggested that thermotolerance may be associated with the pathogenicity of the organism (87) which may explain why dried infant formula is implicated so often with $E$. sakazakii infection.

In order to determine if desiccation contributes to physiological changes in $E$. sakazakii, the BIOLOG microplate system was used in the current study. The use of the BIOLOG identification system was originally evaluated by Miller and Rhoden (55) for its ability to correctly identify clinical and environmental isolates. The microtiter plate contains a panel of 95 different carbon sources, ranging from organic acids to sugars. In theory, different species should produce an individual pattern of positive purple wells which would make up a "metabolic fingerprint" (26). Ihssen and Egli (35) used the BIOLOG system to distinguish between repressed and induced catabolic functions in $E$. coli which had been exposed to low concentrations of a mixed carbon and energy source pool. BIOLOG microtiter analysis demonstrated that numerous catabolic functions were repressed under glucose or arabinose limited growth conditions, while cells grown in 
complex mixed chemostat cultures showed a high level of catabolic flexibility with utilization of 43 substrates (35). These results suggest that the BIOLOG assay system has the ability to provide catabolic data from a pure culture after differing growth conditions.

In the present study, the physiological differences associated with the desiccation of E. sakazakii were determined with the use BIOLOG microplate system. Desiccated E. sakazakii was exposed to heat-stress, and the cultivation of cells on a non-selective medium was used to determine thermotolerance. In combination with cell counts, the potential utilization of 95 different carbon substrates in BIOLOG microplates were used to establish metabolic changes as a result of desiccation and exposure to heat stress.

\section{Methods}

\subsection{Desiccation of E. sakazakii cells}

E. sakazakii was grown in $50 \mathrm{ml}$ of TSB at $35^{\circ} \mathrm{C}$ for $24 \mathrm{~h}$. Cells were centrifuged and washed as previously described (Chapter 1). Ten ml of washed cells were poured into a $25 \mathrm{ml}$ reservoir containing $5 \mathrm{ml}$ of $0.1 \%$ peptone. Cells were then transferred into an empty 96 well microplate by adding $150 \mu \mathrm{l}$ into each well. The microplate was placed into a $25^{\circ} \mathrm{C}$ incubator without the lid and air dried for $48 \mathrm{~h}$. After $48 \mathrm{~h}$ sufficient desiccation had occurred and the lid was replaced to minimize contamination. After 7 days, cells were placed in an aqueous environment by adding $150 \mu 1$ of $0.1 \%$ peptone buffer into each well. The microplate was then shaken for $5 \mathrm{~min}$, and the cells were pipetted out of each well into a $25 \mathrm{ml}$ reservoir. Cells were harvested and exposed to heat stress as stated previously in Chapter 1. 


\subsection{Survival and water activity determination of desiccated cells}

D-values were determined using TSA (calculated as previously described in Chapter 1) in order to compare thermotolerance of non-desiccated cells versus desiccated cells when exposed to heat stress $\left(52^{\circ} \mathrm{C}\right)$.

Enterobacter sakazakii cells grown in $50 \mathrm{ml}$ of $\mathrm{TSB}$ at $35^{\circ} \mathrm{C}$ for $24 \mathrm{~h}$ were washed with $0.1 \%$ peptone and $10 \mathrm{ml}$ were added to $\mathrm{a} \mathrm{a}_{\mathrm{w}}$ analysis container. The container was then placed in the $25^{\circ} \mathrm{C}$ incubator with the lid off until sufficient desiccation of cells had taken place, at which time the lid was placed back on to eliminate contamination. After 7 days, the container was removed from the incubator and water activity was determined with a water activity meter (Hygrolab 3; Rotronic Instrument Corp, Huntington, NY, USA). Water activity was determined to be 0.69 .

\subsection{Carbon source utilization patterns}

Carbon source utilization patterns of desiccated cells and non-desiccated cells, both heat-stressed and non-heat-stressed, were examined with BIOLOG GN microtiter plates as described previously in Chapter 1. Absorbance data were collected at $595 \mathrm{~nm}$ using a spectrophotometer (SpectraMax 340PC). BIOLOG microtiter plates were incubated at $35^{\circ} \mathrm{C}$ and read every $24 \mathrm{~h}$ for $96 \mathrm{~h}$. Average well color development (AWCD) was determined by the average absorbance levels of all 95 substrates for each reading. In addition, sole-source carbon utilization patterns were separated by guilds as described by Zak et al. (50). Guilds are created according to the chemical nature of the substrate and therefore provide additional analysis on utilization of specific types of substrates after exposure to heat stress. 


\subsection{Statistical analysis}

Data from the BIOLOG microplates were taken from Soft MAX Pro (version

3.2.1) and transferred onto an Excel spreadsheet. The final reading was used to calculate the area under the curve (AREA) described previously in Chapter 1. Students t-test was used to determine significant differences $(\mathrm{p}<0.05)$.

\section{Results and discussion}

\subsection{Exposure to heat stress and survival curves}

Desiccated cells were more thermotolerant than non-desiccated cells (Fig. 3.1). After 90 min exposure of heat stress, an approximate $1.4 \log$ reduction $\left(\mathrm{D}_{52}=69.93\right)$ in survivors was detected on TSA for desiccated cells compared to a $2.5 \log$ reduction $\left(\mathrm{D}_{52}=\right.$ 69.93) for non-desiccated cells (Fig. 3.1). The observed decrease in sensitivity towards heat stress of desiccated cells supports an earlier finding by Riedel and Lehner (66), wherein an up regulation of a heat shock protein in desiccated Enterobacter sakazakii was observed.

\subsection{Effect of desiccation on substrate utilization of heat-stressed cells as determined by the BIOLOG plate system with the use of AWCD and guild groupings}

Based on average well color development (AWCD), a measure of catabolic flexibility, an overall decrease in utilization of substrates was observed for desiccated $E$. sakazakii compared to non-desiccated cells (Table 3.1). The decrease in AWCD indicates that desiccated cells, although more resistant to stress, may be initially less metabolically active. 


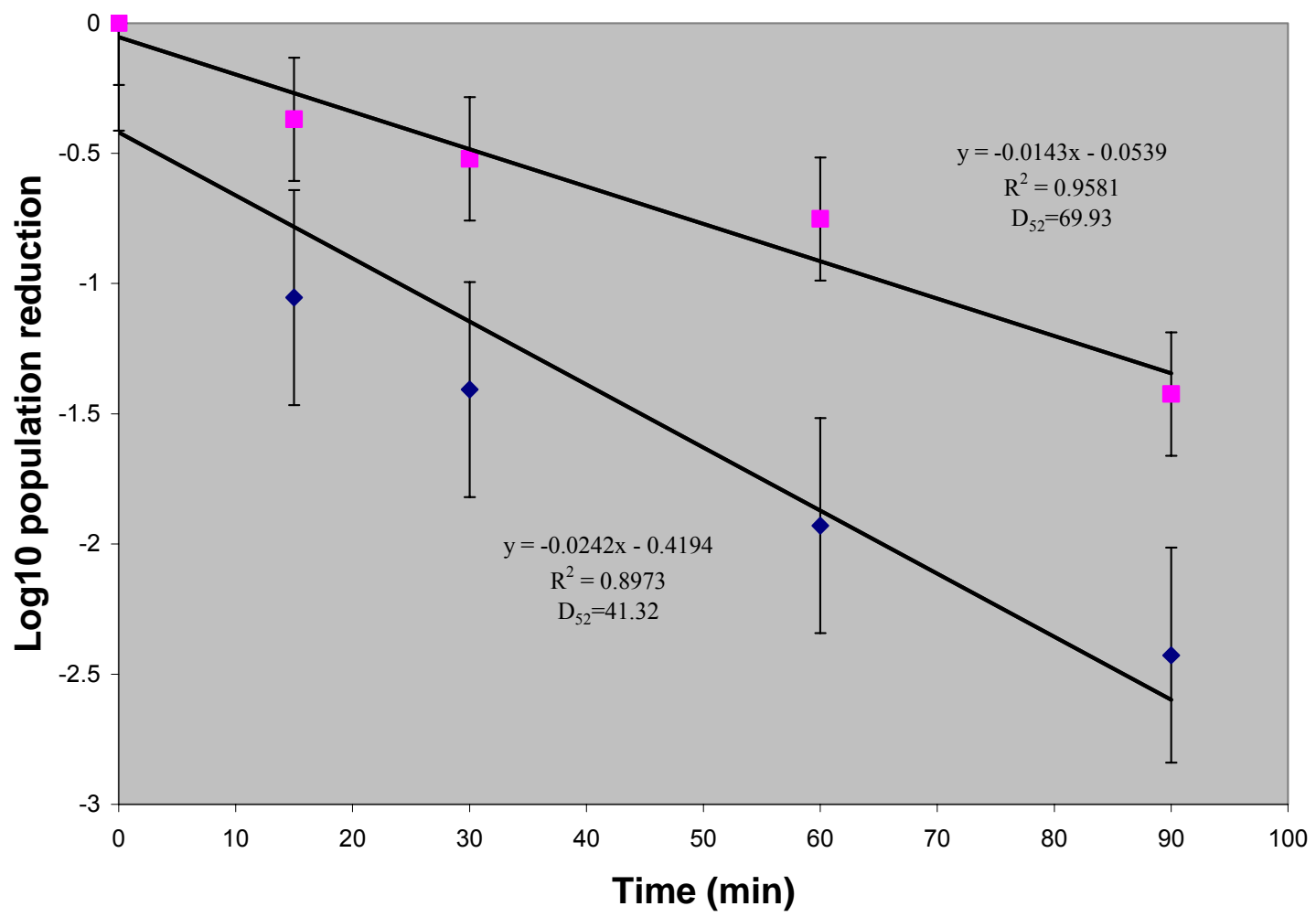

FIG. 3.1. D-value determinations of thermally-stressed $\left(52^{\circ} \mathrm{C}\right) \boldsymbol{E}$. sakazakii as influenced by desiccation (non-desiccated $\$$; and desiccated $\mathbf{\Lambda}$ ). Cell counts were graphed using linear regression of the survival curve (triplicate TSA counts) to determine the slope. Bars represent the standard error. Each point represents the average of three independent experiments. 
Utilization patterns as related to substrate guilds in BIOLOG microtiter plates were initially characterized by Zak et al. (50). In our study, guild groupings demonstrated that non-heated desiccated cells had an increase in carbohydrate and polymer utilization as compared to $90 \mathrm{~min}$ heat-stressed desiccated cells (Fig. 3.2). The carbohydrate guild consists mainly of simple sugars, which when degraded lead to production of intermediates used in the TCA, pentose-phosphate, and glycolytic catabolic pathways.

Control cells desiccated and non-desiccated demonstrated the a similar utilization for all guilds (Fig. 3.3). Ninety min heat-stressed cells previously desiccated and not desiccated demonstrated no significant differences in utilization of guilds, however the polymer guild showed the largest difference in utilizaiton (Fig. 3.3).

\subsection{Effect of desiccation on specific substrate utilization of heat- stressed cells as determined by the BIOLOG plate system}

Desiccated and non-desiccated E. sakazakii demonstrated a high similarity in utilization

of specific substrates found in the BIOLOG microtiter plate. However, notable exceptions for a limited number of substrates were observed for heat-stressed $E$. sakazakii suggesting that the BIOLOG system may be useful for identifying the physiological response of these cells exposed to environmental stress. For example, desiccated cells exposed to 90 min of heat consistently showed a complete shut down of the $\beta$-methyl-glucoside catabolic pathway when compared to desiccated non-heated control cells and non-desiccated 90 min heat-stressed cells (Table 3.2 and 3.3; Fig. 3.43.5 in Appendix). 
TABLE 3.1. Average well color development (AWCD) of E. sakazakii following heat stress $\left(52^{\circ} \mathrm{C}\right)$ as influenced bv desiccation

\begin{tabular}{lcc}
\hline & AWCD $^{2}$ & \\
\cline { 2 - 3 } Exposure time (min) & Non-desiccated & Desiccated \\
\hline Control $^{b}$ & 0.730 & 0.691 \\
0 & 0.728 & 0.630 \\
15 & 0.689 & 0.570 \\
30 & 0.663 & 0.577 \\
90 & 0.567 & 0.530 \\
\hline
\end{tabular}

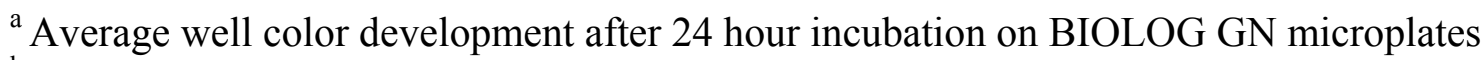

${ }^{\mathrm{b}}$ Cells placed into $99 \mathrm{ml}$ of $0.1 \%$ peptone at $25^{\circ} \mathrm{C}$ 


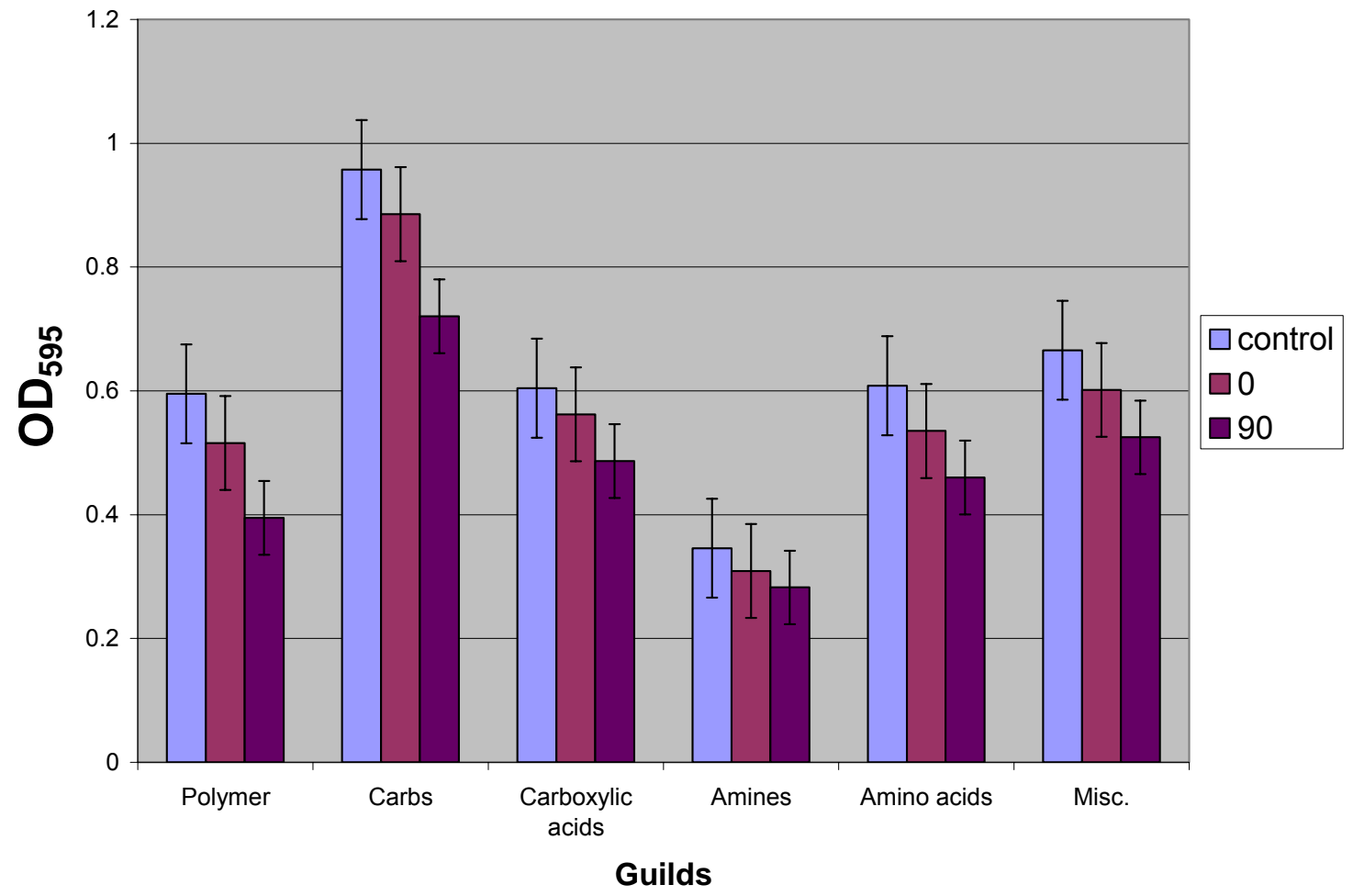

FIG. 3.2. Substrate utilization of BIOLOG guilds (expressed as average AREA) for heat stressed $\left(52^{\circ} \mathrm{C}\right.$ for $\left.90 \mathrm{~min}\right)$ E. sakazakii previously

desiccated. BIOLOG GN substrates were categorized into six guilds as described by Zak et al. (1994). Color formation was read after $24 \mathrm{~h}$ incubation. Error bars represent standard error. 


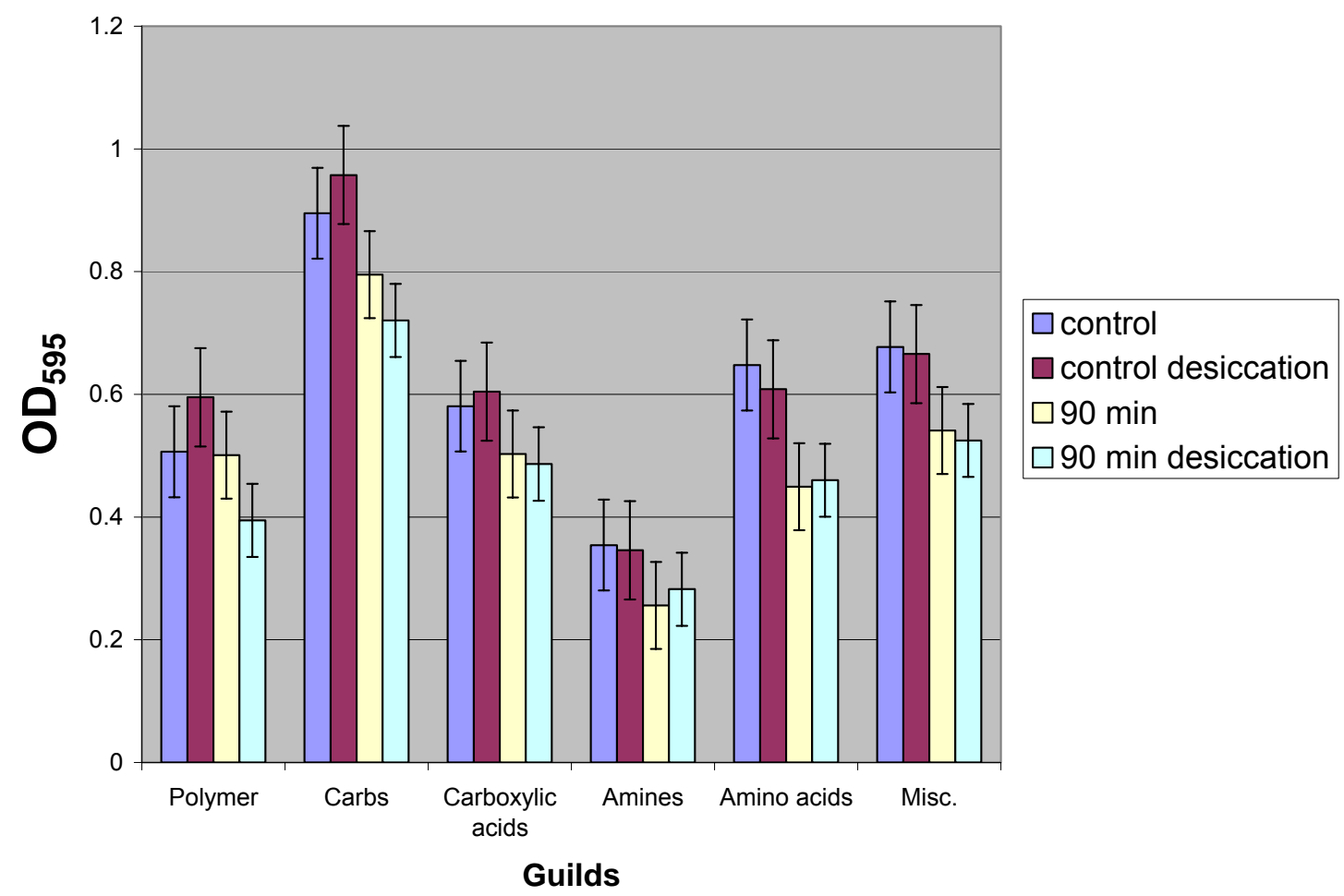

FIG. 3.3. Substrate utilization of BIOLOG guilds (expressed as average AREA) for $90 \mathrm{~min}$ heat-stressed $\left(52^{\circ} \mathrm{C}\right.$ for $\left.90 \mathrm{~min}\right) \mathrm{E}$. sakazakii previously desiccated and not desiccated. BIOLOG GN microtiter plates were categorized into six guilds as described by Zak et al. (1994). Color formation was read after $24 \mathrm{~h}$ incubation. Error bars represent standard error. 
$\beta$-glucosides when metabolized are broken down to produce $\beta$-glucose or glucoside-6-phosphate. Kharat and Mahedevan (42) have shown that members of the Enterobacteriaceae exhibit varying abilities to utilize $\beta$-glucosides, and in E. coli the bgl operon encodes the necessary functions for transport and metabolism. The bgl operon, however, is unable to be induced without a previous mutational event. The reported crypticity of the bgl operon leads wildtype E.coli to maintaining a structurally functional form of the gene in the operon but it is unable to be induced (42). The crypticity of this operon becomes even more complicated when observing other enteric bacteria. Shigella sonnei is split into two classes based on its capability to utilize $\beta$-glucosides. Class I S. sonnei has the capability of mutating to be able to express the gene and utilize $\beta$ glucosides, while class II is unable to express a mutated functional form of the gene (42). A stress-induced genetic change associated with the utilization of carbon substrates is reported to occur in a reversal of the lac frameshift allele allowing E. coli to grow on a lactose medium (32). With these results in mind, a mutational event caused by exposure to desiccation or heat stress could potentially have influenced the bgl operon to shutdown in E. sakazakii as reflected by its known crypticity.

Increased utilization of L-pyroglutamic acid and xylitol was observed in $E$. sakazakii exposed to 90 min of heat stress previously desiccated when compared to nonheated control cells that were not previously desiccated (Table 3.2). Previously (see Chapter 2), xylitol was shown to be an important substrate for 90 min heat-stressed $E$. sakazakii. Xylitol is known to be metabolized in the pentose-phosphate pathway and is a key intermediate in the biosynthesis of aromatic amino acids (13). L-pyroglutamic acid is a cyclical amino acid and may be utilized during amino acid metabolic pathways or 
biosynthesis of proteins as the amino-terminal residue (1). The increased utilization of xylitol and L-pyroglutamic acid may indicate an increased need for proteins and enzymes to aid in the repair of injury due to desiccation and exposure to heat stress.

The previous experiment demonstrated a change in metabolism of E. sakazakii due to desiccation and exposure to heat stress. In order to determine if the desiccation of cells without exposure to heat stress could also influence metabolism, non-heated control cells that were previously desiccated were compared to non-heated control cells there were not previously desiccated (Table 3.3). Results showed that nearly all of the 95 substrates were utilized equally; however, increased utilization of xylitol and adonitol was observed desiccated cells (Table 3.3). In previous experiments, the increased utilization of xylitol and adonitol was only seen for E. sakazakii exposed to $90 \mathrm{~min}$ of heat stress. This observation that non-heated control cells previously desiccated had a significant $(\mathrm{p}<0.05)$ increase in utilization of xylitol and adonitol suggests that desiccation does cause a shift in the catabolic pathways of E. sakazakii.

In addition, these observations may also suggest that xylitol and adonitol may be related to the general stress response of E. sakazakii. Future studies are needed to determine the role of xylitol and adonitol in the metabolism of environmentally stressed E. sakazakii. 
TABLE 3.2. Utilization of specific BIOLOG substrates by desiccated heatstressed $\left(52^{\circ} \mathrm{C}\right.$ for $\left.90 \mathrm{~min}\right)$ Enterobacter sakazakii compared to substrate utilization by non-heated control cells.

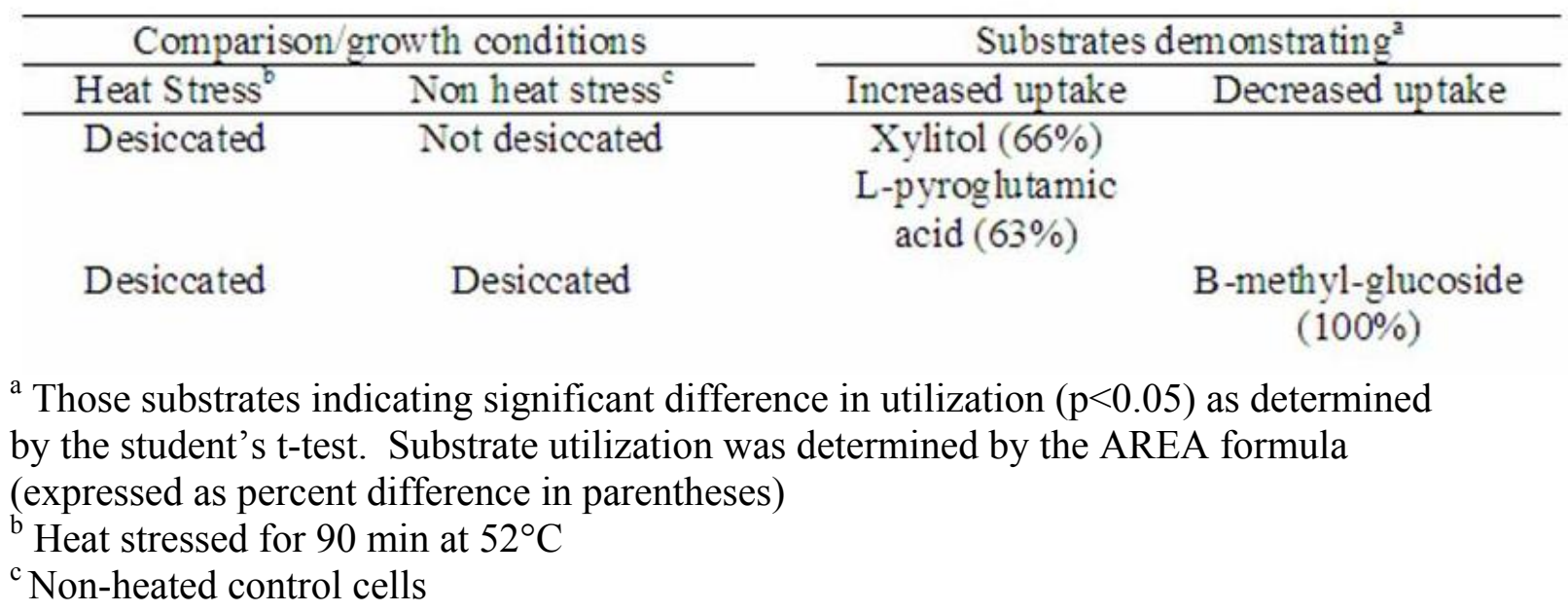


TABLE 3.3. Utilization of specific BIOLOG substrates by desiccated Enterobacter sakazakii exposed to heat or no heat compared to substrate utilization by non-desiccated cells.

\begin{tabular}{|c|c|c|c|}
\hline \multicolumn{2}{|c|}{ Comparison/growth conditions } & \multicolumn{2}{|c|}{ Substrates demonstrating ${ }^{2}$} \\
\hline Desiccation & Nodesiccation & Increased uptake & Decreased uptake \\
\hline Heat stress ${ }^{b}$ & heat stress ${ }^{b}$ & & $\begin{array}{l}\text { B-methyl-glucoside } \\
(100 \%)\end{array}$ \\
\hline No heat stress ${ }^{\circ}$ & No heat stress ${ }^{c}$ & $\begin{array}{l}\text { Xylitol }(64 \%) \\
\text { Adonitol }(38 \%)\end{array}$ & \\
\hline
\end{tabular}

${ }^{a}$ Those substrates indicating significant difference in utilization $(\mathrm{p}<0.05)$ as determined by the student's t-test. Substrate utilization was determined by the AREA formula (expressed as percent difference in parentheses)

${ }^{\mathrm{b}}$ Heat stressed for $90 \mathrm{~min}$ at $52^{\circ} \mathrm{C}$

${ }^{\mathrm{c}}$ Non-heated control cells 


\section{Summary}

In the current study, possible physiological changes associated with the desiccation of E. sakazakii were evaluated with the BIOLOG microplate system. Specific findings include:

- Desiccation $\left(\mathrm{a}_{\mathrm{w}}=0.69\right)$ resulted in increased thermotolerance $\left(\mathrm{D}_{52}=69.93\right)$ of survivors compared to non-desiccated cells $\left(\mathrm{D}_{52}=41.32\right)$. The ability of $E$. sakazakii to survive desiccation while simultaneously becoming less sensitive to heat stress may be an important factor contributing to the significance of this opportunistic pathogen in dried infant formula.

- The use of the BIOLOG system demonstrated that the AWCD of heat-stressed E. sakazakii was influenced by desiccation, resulting in a reduced AWCD. The generalized application of the BIOLOG system using guild groupings proved to be contradictory to the observed AWCD results, demonstrating an increase in utilization of guilds by desiccated E. sakazakii. The differing results reported for AWCD and guild groupings suggest that they are relatively insensitive as an assay of physiological change in desiccated E. sakazakii exposed to heat stress.

- Notable differences in specific substrate utilization were observed between desiccated and non-desiccated E. sakazakii. Additionally, the alterations in utilization of specific substrates were observed between heat-stressed and nonheated control cells, and desiccated and non-desiccated cells. The reported results suggest that the BIOLOG system may have the capability of identifying metabolic differences in environmentally stressed E. sakazakii. 
5. Appendix 

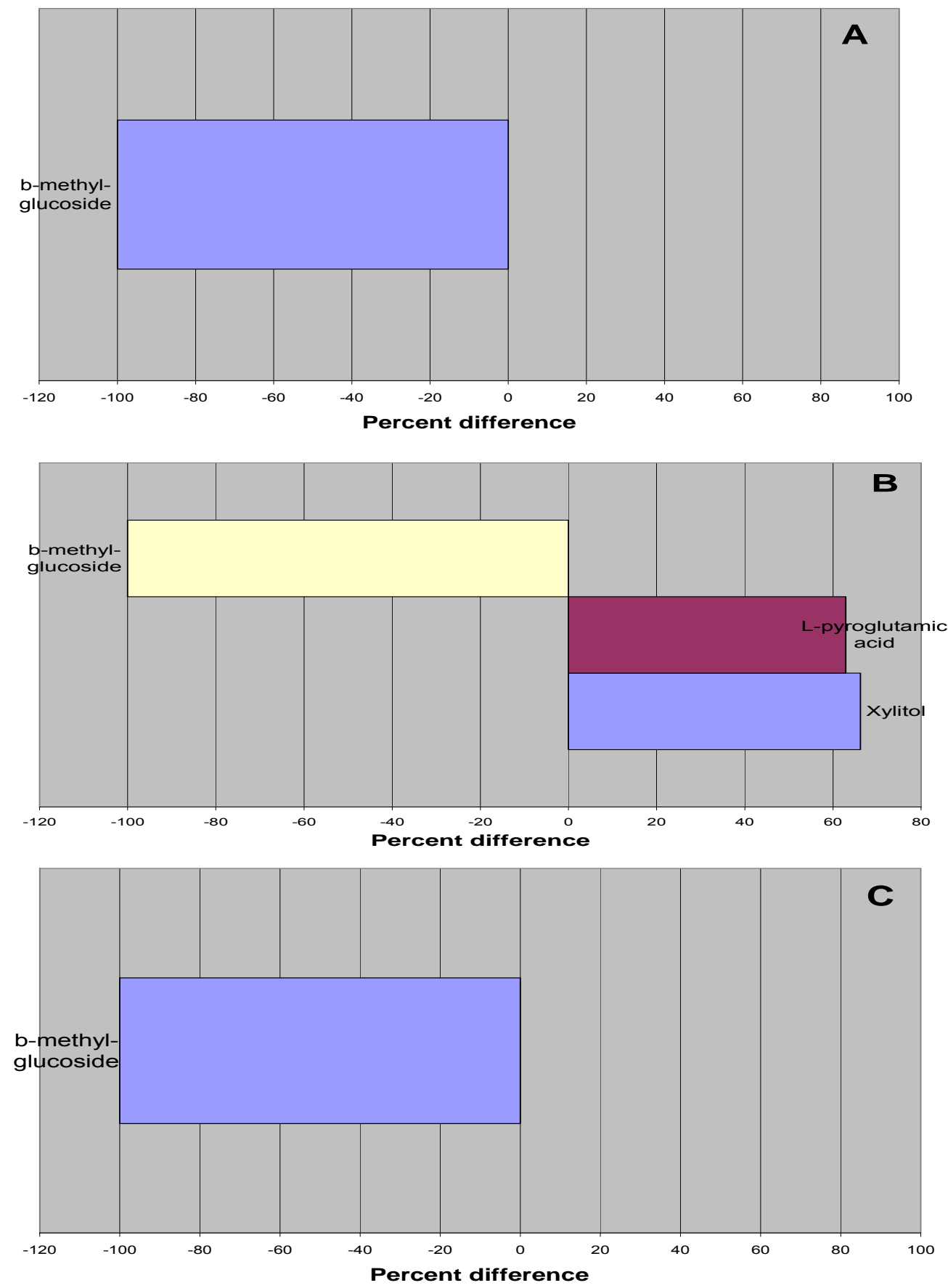

FIG. 3.4. Differences in substrate utilization of desiccated $E$. sakazakii cells exposed to 90 min of heat stress compared to substrate utilization of non-heated control cells previously A) desiccated, B) not desiccated, and C) $90 \mathrm{~min}$ heat stressed cells not previously desiccated. Substrate utilization was determined using the AREA formula, and graphed as percent difference in utilization. 


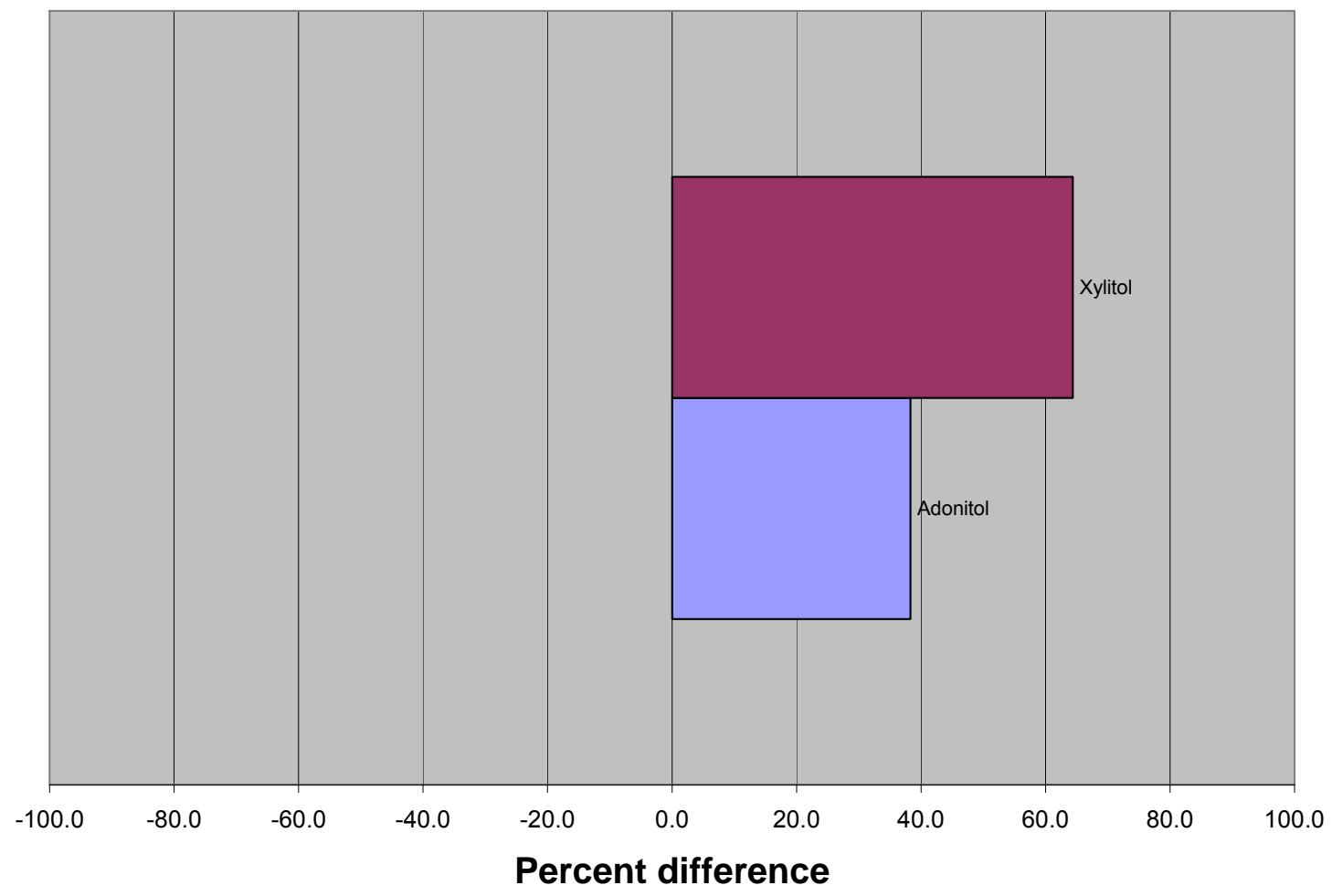

FIG. 3.5. Differences in substrate utilization of non-heated control $E$. sakazakii cells previously desiccated compared to substrate utilization non-heated control cells not previously desiccated. Substrate utilization was determined using the AREA formula, and graphed as percent difference in utilization. 


\section{Literature Cited}

1. Abraham, G., and Podell, D. 1981. Pyroglutamic acid. Mol. Cell. Biochem. 38:181-190.

2. Aertsen, A., and Michiels, C. 2004. Stress and how bacteria cope with death and survival. Crit. Rev. Microbiol. 30:263-273.

3. Arsene, F., Tomoyasu, T., and Bukau, B. 2000. The heat shock response of Escherichia coli. Internat. J. Food Microbiol. 55:3-9.

4. Baudart, J., Lemarchand K., Brisabois, A., and Lebaron, P. 2000. Diversity of Salmonella strains from the aquatic environment as determined by serotyping and amplification of the ribosomal DNA spacer regions. Appl. Environ. Microbiol. 66:1544-1552.

5. Berney, M., Weilenmann, H., Ihssen, J., Bassin, C., and Egli, T. 2006. Specific growth rate determines the sensitivity of Escherichia coli to thermal, UVA, and solar disinfection. Appl. Environ. Microbiol. 72:2586-2593.

6. Besse, N., and Leclercq, A. 2006. Evaluation of the international organization for standardization-international dairy federation (ISO-IDF) draft standard method for detection of Enterobacter sakazakii in powdered infant food formulas. J. AOAC Int. 89:1309-1316.

7. Bierling, G., Karlsson, S., Clark, N., Jonsdottir, K., Ludvigs-Wachsmuth, I., and Farmer, J. 1983. Analysis of eight cases of neonatal meningitis and sepsis due to Enterobacter sakazakii. J. Clin. Microbiol. 18:115-120.

8. Billi, D., Wright, D., Helm, R., Pricket, T., Potts, M., and Crowe, J. 2000. Engineering desiccation tolerance in Escherichia coli. Appl. Environ. Microbiol. 66: $1680-1684$.

9. Blattner, F., Plunkett, G., Bloch, C., Perna, N., Burland, V., Riley, M., Collado-Vides, J., Glasner, J., Rode, C., Mayhew, G., Gregor, J., Davis, N., Kirkpatrick, H., Goeden, M., Rose, D., Mau, B., and Shao, Y. 1997. The complete genome sequence of Escherichia coli K-12. Science. 277:1453-1462.

10. Brenner, K., Rankin, C., Sivaganessan, M., and Scarpino P. 1996. Comparison of the recoveries of Escherichia coli and total coliform from drinking water by the MI agar method and the U.S. environmental protection agency approved membrane filter method. Appl. Environ. Microbiol. 62:203-208.

11. Breeuwer, P., Lardeau, A., Peterz, M., and Joosten, H. 2003. Desiccation and heat tolerance of Enterobacter sakazakii. J. Appl. Microbiol. 95:967-973.

12. Bunning, V., Crawford, R., Tierney, J., and Peeler, J. 1990. Thermotolerance of Listeria monocytogenes and Salmonella typhimurium after sublethal heat shock. Appl. Environ. Microbiol. 56:3216-3219.

13. Caspi, R., Foerster, H., Fulcher, C., Hopkinson, R., Ingraham, J., Kaipa, P., Krummenacker, M., Paley, S., Pick, J., Rhee, S., Tissier, C., Zhang, P., and Karp, P. 2006. MetaCyc: a multiorganism database of metabolic pathways and enzymes. Nucleic Acids Res. 34:D511-D516. 
14. Davey, H., and Kell, D. 1996. Flow cytometery and cell sorting of heterogeneous microbial populations: the importance of single-cell analyses. Microbiol. Rev. 60:641-696.

15. Doten, R., and Mortlock, R. 1985. Inducible xylitol dehydrogenases in enteric bacteria. J. Bacteriol. 162:845-848.

16. Edelson-Mammel, S., and Buchanan, R. 2004. Thermal inactivation of Enterobacter sakazakii in rehydrated infant formula. J. Food Prot. 67:60-63.

17. El-Samad, H., Kurata, H., Doyle, J., Gross C., and Khammash, M. 2005. Surviving heat shock: control strategies for robustness and performance. PNAS. 102:2736-2741.

18. Engelen B., Meinken, K., von Wintzingerode, F., Heuer, H., Malkomes, H., and Backhaus, H. 1998. Monitoring impact of a pesticide treatment on bacterial soil communities by metabolic and genetic fingerprinting in addition to conventional testing procedures. Appl. Environ. Microbiol. 64:2814-2821.

19. Erickson, M., and Kornacki, J. 2002. Enterobacter sakazakii: an emerging food pathogen. Univ. of Georgia, Center for Food Saftey.

http://www.ugacfs.org/faculty/Erickson/EBWhitePaper.mpd.PDF

20. Fanjat, N., Leclerq, A., Joosten, H., and Robichon, D. 2007. Comparison of the phenotyping methods ID 32E and VITEK 2 compact GN with 16S rRNA gene sequencing for the identification of Enterobacter sakazakii. J. Clinical Microbiol. 45:2048-2050.

21. Farewell, A., Kvint, K., and Nystrom, T. 1998. uspB, a new $\sigma^{\mathrm{s}}$-regulated gene in Escherichia coli which is required for stationary-phase resistance to ethanol. J. Bacteriol. 180: 6140-6147.

22. Farmer, J., Asbury, M., Hickman, F., and Brenner, D. 1980. Enterobacter sakazakii: a new species of "Enterobacteriaceae" isolated from clinical specimens. Int. J. Syst. Bacteriol. 30:569-584.

23. Faure, D., Saier M., and Vanderleyden, J. 2001. An evolutionary alternative system for aryl $\beta$-glucosides assimilation in bacteria. J. Mol. Microbiol. Biotechnol. 3:467-470.

24. Friedman M. S., M. Hossain, T. H. Hasson, and A. Kawamura. 2005. Gene expression profiling of intrinsic thermotolerance in Escherichia coli. Current Microbiol. 52:50-54.

25. Gales, A., Reis, A., and Jones, R. 2001. Contemporary assessment of antimicrobial susceptibility testing methods for Polymyxin B and Colistin: review of available interpretative criteria and quality control guidelines. J. Clinical Microbiol. 39:183-190.

26. Garland, J., and Mills, A. 1991. Classification and characterization of heterotrophic microbial communities on the basis of patterns of community level sole carbon source utilization. Appl. Environ. Microbiol. 57:2351-2359.

27. Guckert, J., Carr, G., Johnson, T., Hamm, B., Davidson, D., and Kumagai, Y. 1996. Community analysis of Biolog: curve integration for statistical analysis of activated sludge microbial habitats. J. Microbiol. Methods. 27:183-197.

28. Hackett, C., and Griffiths, B. 1997. Statistical analysis of the time-course of Biolog substrate utilization. J. Microbiol. Methods. 30:63-69. 
29. He, Y., Kashiwagi, K., Fukuchi, J., Terao, K., Shirahata, A., and Igarashi, K. 1993. Correlation between the inhibition of cell growth by accumulated polyamines and the decrease of magnesium and ATP. Eur. J. Biochem. 217:8996.

30. Hengge-Aronis, R., Klein, W., Lange, R., Rimmele, M., and Boos, W. 1991. Trehalose synthesis genes are controlled by the putative sigma factor encoded by rpoS and are involved in stationary-phase thermotolerance in Escherichia coli. J. Bacteriol. 173:7918-7924.

31. Herendeen, S., Van Bogelen, R., and Neidhardt, F. 1979. Levels of major proteins of Escherichia coli during growth at different temperatures. J. Bacteriol. 139:185-194.

32. Hersh, M., Ponder, R., Hastings, P., and Rosenberg, S. 2004. Adaptive mutation and amplification in Escherichia coli: two pathways of genome adaptation under stress. Res. Microbiology 155:352-359.

33. Higgins, C., Dorman, C., Stirling, D., Waddell, L., Booth, I., May, G., and Bremer, E. 1988. A physiological role for DNA supercoiling in the osmotic regulation of gene expression in S. typhimurium and E. coli. Cell. 52:569-584.

34. Ihssen, J., and Egli, T. 2004. Specific growth rate and not cell density controls the general stress response in Escherichia coli. Microbiol. 150:1637-1648.

35. Ihssen, J., and Egli, T. 2005. Global physiological analysis of carbon and energy limited growing Escherichia coli confirms a high degree of catabolic flexibility and preparedness for mixed substrate utilization. Environ. Microbiol. 7: 15681581.

36. Iversen, C., and Forsythe, S. 2004. Isolation of Enterobacter sakazakii and other Enterobacteriaceae from powdered infant formula and related products. Food Microbiol. 21:771-776.

37. Iversen, C., Lane, M., and Forsythe S. 2004. The growth profile, thermotolerance and biofilm formation of Enterobacter sakazakii grown in infant formula milk. Lett. Appl. Microbiol. 38:378-382.

38. Jenkins, D., Shultz, J., and Matin, A. 1988. Starvation-induced cross protection against heat or $\mathrm{H}_{2} \mathrm{O}_{2}$ challenge in Escherichia coli. J. Bacteriol. 170:3910-3914.

39. Kandhai, M., Reij, M., Grognou, C., van Schothorst, M., Gorris, L., and Zwietering, M. 2006. Effects of preculturing conditions on lag time and specific growth rate of Enterobacter sakazakii in reconstituted powdered infant formula. Appl. Environ. Microbiol. 72:2721-2729.

40. Kepner, R., and Pratt, J. 1994. Use of fluorochromes for direct enumeration of total bacteria in environmental samples: past and present. Microbiol. Rev. 58: 603-615.

41. Kessler, I., Collado-Vides, J., Gama-Castro, S., Ingraham, J., Paley, S., Paulsen, I., Peralta-Gil, M., and Karp, P. 2005. EcoCyc: a comprehensive database resource for Escherichia coli. Nucleic Acids Res. 33:D334-D337.

42. Kharat, A., and Mahadevan, S. 2000. Analysis of the $\beta$-glucoside utilization (bgl) genes of Shigella sonnei: evolutionary implications for their maintenance in a cryptic state. Microbiology 146:2039-2049. 
43. Kim, H., Ryu, J., and Beuchat, L. 2007. Effectiveness of disinfectants in killing Enterobacter sakazakii in suspension, dried on the surface of stainless steel, and in a biofilm. Appl. Environ. Microbiol. 73:1256-1265.

44. Knabel, S., Walker, H., Hartman, P., and Mendonca, A. 1990. Effects of growth temperature and strictly anaerobic recovery on the survival of Listeria monocytogenes during pasteurization. Appl. Environ. Microbiol. 56:370-376.

45. Lehner, A., Riedel, K., Eberl, L., Breeuwer, P., Diep, B., and Stephan, R. 2005. Biofilm formation, extracellular polysaccharide production, and cell-to-cell signaling in various Enterobacter sakazakii strains: aspects promoting environmental persistence. J. Food Prot. 68:2287-2294.

46. Leslie, S., Israeli, E., Lighthart, B., Crowe, J., and Crowe, L. 1995. Trehalose and sucrose protect both membranes and proteins in intact bacteria during drying. Appl. Envrion. Microbiol. 61:3592-3597.

47. Leuscher, R., Baird, F., Donald, B., and Cox, L. 2004. A medium for the presumptive detection of Enterobacter sakazakii. Appl. Environ. Microbiol. 21:604-613.

48. Lim, C., and Flint, K., 1989. The effects of nutrients on the survival of Escherichia coli in lake water. J. Appl. Bacteriol. 66:559-569

49. Lindstrom, J., Barry, R., and Braddock, J. 1998. Microbial community analysis: a kinetic approach to constructing potential $\mathrm{C}$ source utilization patterns. Soil Biol. Biochem. 30:231-239.

50. Lohrke, S., Dery, P., Li, W., Reedy, R., Kobayashi, D., and Roberts, D. 2002. Mutation of rpiA in Enterobacter cloacae decreases seed and root colonization and biocontrol of damping-off caused by Pythium ultimum on cucumber. MPMI. 15:817-825.

51. Lopez-Campistrous, A., Semchuck, P., Burke, L., Palmer-Stone, T., Brokx, S., Broderick, G., Bottorff, D., Bolch, S., Weiner, J., and Ellison, M. 2005. Localization, annotation, and comparison of the Escherichia coli K-12 proteome under two states of growth. Mol. Cell. Proteom. 4:1205-1209.

52. Mason, C., Dunner, J., Indra, P., and Colangelo, T. 1999. Heat-induced expression and chemically induced expression of the Escherichia coli stress protein HtpG are affected by the growth environment. Appl. Environ. Microbiol. 65:3433-3440.

53. Matthews, R., and Neidhardt, F. 1989. Elevated serine catabolism is associated with the heat shock response in Escherichia coli. J. Bacteriol. 171:2619-2625.

54. McDouglad, D., Rice, S., Weichart, D., and Kjelleberg, S. 1998. Nonculturability: adaptation or debilitation? Microbiol. Ecol. 25:1-9.

55. Miller M., and Rhoden D. 1991. Preliminary evaluation of BIOLOG, a carbon source utilization method for bacterial identification. J. Clinical Microbiol. 29:1143-1147.

56. Mortlock, R. 1983. Experiments in evolution using microorganisms. BioScience. 33:308-313.

57. Mullane, N., Drudy, D., Whyte, P., O’Mahony, M., Scannell, A., Wall, P., and Fanning, S. 2006. Enterobacter sakazakii: biological properties and significance in dried infant milk formula (IMF) powder. Int. J. Dairy Tech. 59:102-111. 
58. Muytjens, H., Roelofs-Willemse, H., and Jaspar, G. 1988. Quality of powdered substitutes for breast milk with regard to members of the family

Enterobacteriaceae. J. Clin. Microbiol. 26:743-746.

59. Nazarowec-White, and M., Farber, J. 1997. Thermal resistance of Enterobacter sakazakii in reconstituted dried-infant formula. Lett. Appl. Microbiol. 24:9-13.

60. Neidhardt, F., Curtiss, R., Ingraham, J., Lin, E., Low, K., Magasanik, B., Reznikoff, W., Riley, M., Schaechter, M., and Umbarger, H. 1996.

Escherichia coli and Salmonella. Cellular and Molecular Biology, $2^{\text {nd }}$ ed. ASM Press, Washington, DC.

61. O'Neill, C., and Bissonnette, G. 1991. Antecedent oxygen growth conditions and recovery of heat-stressed Escherichia coli. J. Food Prot. 54:90-93.

62. Postupa, R., and Aldova, E. 1984. Enterobacter sakazakii: a tween 80 esterasepositive representation of the genus Enterobacter isolated from powdered milk specimens. J. Hyg., Epidemiol., Microbiol., Immunol. 28:435-440.

63. Preston-Mafham, J., Boddy, L., and Randerson, F. 2002. Analysis of microbial community functional diversity using sole-carbon-source utilisation profiles - a critique. Microbiol. Ecol. 42:1-14.

64. Quan, J., Schneider, B., Paulsen, I., Yamada, M., Kredich, N., and Saier, M. 2002. Regulation of carbon utilization by sulfur availability in Escherichia coli and Salmonella typhimurium. Microbiology 148:123-131.

65. Record, M., Courtenay, E., Cayley, D., and Guttman, H. 1998. Responses of E. coli to osmotic stress: large changes in amounts of cytoplasmic solutes and water. Trends Biol. Sci. 23:143-148.

66. Reidel, K., and Lehner, A. 2007. Identification of proteins involved in osmotic stress response in Enterobacter sakazakii by proteomics. Proteomics. 7:12171231.

67. Reitzer, L. 2003. Nitrogen assimilation and global regulation in Escherichia coli. Ann. Rev. Microbiol. 57:155-176.

68. Richards, G., Gurtler, J., and Beuchat, L. 2005. Survival and growth of Enterobacter sakazakii in infant rice cereal reconstituted with water, milk, liquid infant formula, or apple juice. J. Appl. Microbiol. 99:844-850.

69. Riordan, D., Duffy, G., Sheridan, J., Whiting, R., Blair, I., and McDowell, A. 2000. Effects of acid adaptation, product $\mathrm{pH}$, and heating on survival of

Escherichia coli O157:H7 in pepperoni. Appl. Environ. Microbiol. 66:1726-1729.

70. Rolling, W., van-Breukelen, B., Braster, M., Goeltom, M., Groen J., and van Verseveld H. 2000. Analysis of microbial communities in a landfill leachate polluted aquifer using a new method for anaerobic physiological profiling and 16S rDNA based fingerprinting. Microb. Ecol. 40:177-188.

71. Roszak, D., and Colwell, R. 1987. Survival strategies of bacteria in the natural environment. Microbiol. Rev. 51:365-379.

72. Rowe, M., and Kirk, R. 1999. An investigation into the phenomenon of crossprotection in Escherichia coli O157:H7. Food Microbiol. 16:157-164.

73. Savichtcheva, O., Okayama, N., Ito, T., and Okabe, S. 2005. Application of a direct fluorescence-based live/dead staining combined with fluorescence in situ hybridization for assessment of survival rate of Bacteroides spp. in drinking water. Biotech. Bioeng. 92:356-363. 
74. Scangos, G., and Reiner, A. 1978. Ribitol and D-arabitol catabolism in Escherichia coli. J. Bacteriol. 134:492-500.

75. Schiefner, A., Breed, J., Bosser, L., Kneip, S., Gade, J., Holtmann, G., Diederichs, K., Welte, W., and Bremer, E. 2004. Cation interactions as determinants for binding of the compatible solutes glycine betaine and praline betaine by the periplasmic ligand-binding protein ProX from Escherichia coli. J. Biol. Chem. 279:5588-5596.

76. Siegle, D., and Kolter, R. 1992. Life after log. J. Bacteriol. 174:345-348.

77. Spitzer, J., and Poolman, B. 2005. Electrochemical structure of the crowded cytoplasm. Trends Biochem. 30:536-541.

78. Stewart, M., and Olson, B. 1992. Impact of growth conditions on resistance of Klebsiella pneumoniae to chloramines. Appl. Environ. Microbiol. 58:2649-2653.

79. Tabor, C., and Tabor, H. 1985. Polyamines in microorganisms. Microbiol. Rev. 49:81-99.

80. Thunberg, R., Sexstone, A., Calabrese, J., and Bissonnette, G. 2001. Effects of antecedent fermentative and respiratory growth on the detection of chloraminestressed Escherichia coli and Salmonella typhimurium. Can. J. Microbiol. 47:777-781.

81. Tomoyasu, T., Mogk, A., Langen, H., Goloubinoff, P., and Bukau, B. 2001. Genetic dissection of the roles of chaperones and proteases in protein folding and degradation in the Escherichia coli cytosol. Mol. Microbiol. 40:397-413.

82. Tse-Dinh, Y., Qi, H., and Menzel, R. 1997. DNA supercoiling and bacterial adaptation: thermotolerance and thermoresistance. Trends Microbiol. 5:323-326.

83. Tsuchido, T., Takeuchi, A., and Takano, M. 1992. Synthesis of lipopolysaccharide by Escherichia coli cells recovering from sublethal heat stress. J. App. Bacteriol. 73:531-534.

84. Virta, M., Lineri, S., Kankaanpaa, P., Karp, M., Peltonen, K., Nuutila, J., and Lilius, E. 1998. Determination of complement-mediated killing of bacteria by viability staining and bioluminescence. Appl. Environ. Microbiol. 64:515-519.

85. Volker, U., Mach, H., Schmid, R., and Hecker, M. 1992. Stress proteins and cross-protection by heat shock and salt stress in Bacillus subtilis. J. Gen. Microbiol. 138:2125-2135.

86. Wick, L., and Egli, T. 2004. Molecular components of physiological stress responses in Escherichia coli. Adv. Biochem. Engineer. Biotech. 89:1-45.

87. Williams, T., Monday, S., Edelson-Mammel, S., Buchanan, R., and Musser, S. 2005. A top-down proteomics approach for differentiating thermal resistant strains of Enterobacter sakazakii. Proteomics. 5:4161-4169.

88. Winfield, M., and Groisman, E. 2003. Role of nonhost environments in the lifestyles of Salmonella and Escherichia coli. Appl. Envrion. Microbiol. 69:3687-3694.

89. Wood, J. 1999. Osmosensing by bacteria: signals and membrane-based sensors. Microbiol. Mol. Biol. Rev. 63:230-262.

90. Zak, J., Willig, M., Moorhead, D., and Wildman, H. 1994. Functional diversity of microbial communities: a quantitative approach. Soil Biol. Biochem. 26:11011108 . 
91. Zhang, S., Kingsley, R., Santos, R., Andrews-Polymenis, H., Raffatellu, M., Figueiredo, J., Nunes, J., Tsolis, R., Adams, L., and Baumler, A. 2003.

Molecular pathogenesis of Salmonella enterica serotype Typhimurium induced diarrhea. Infect. Immun. 71:1-12.

92. Zhang, Y., and Griffiths, M. 2003. Induced expression of the heat shock protein genes uspA and grpE during starvation at low temperatures and their influence on thermal resistance of Escherichia coli O157:H7. J. Food Prot. 66:2045-2050. 


\section{VITA}

Matthew G. McCarroll was born on October 18, 1981 in Camden, NJ. He is the son of John G. McCarroll and Clare M. McCarroll. He graduated from Clearview Regional High School (NJ) in 2000. In the fall of 2004 he earned his bachelors of biology degree from Lynchburg College (VA). Along with earning a bachelors degree he received a teacher's licensure for the state of VA. Following graduation, he began teaching high school biology and anatomy and physiology at Liberty High School (VA). A change in direction brought him to West Virginia University to begin pursuing a Master of Science degree in Environmental Microbiology. During the summer of 2005 he worked with Dr. Alan J. Sexstone on a water quality project at the Paradise Lake community. Throughout his time at WVU, he taught biology lab 115 and 117 . He is currently a member of the American Society for Microbiology and American Water Works Association. 